\section{Social Relations, Deprivation and Violence at Schleinbach, Lower Austria. Insights from an Interdisciplinary Analysis of the Early Bronze Age Human Remains}

\author{
Doris Pany-Kucera \\ Michaela Spannagl-Steiner \\ Lukas Waltenberger \\ Walther Parson \\ Christina Strobl \\ Barbara Rendl \\ Lukas Janker \\ Fabian Kanz \\ Katharina Rebay-Salisbury
}

\begin{abstract}
The interdisciplinary analysis of the skeletal remains of 63 individuals from settlement features and graves from Schleinbach in Lower Austria brought new insights into Early Bronze Age social relations, health aspects, signs of stress and trauma patterns. The individuals were buried in two groups of formal graves as well as in former storage pits. Mitochondrial DNA analysis identified genetic relationships between two individuals placed close together in a double grave, and between individuals from a multiple burial. The sex of four children buried in contexts suggestive of violence was revealed by proteomic sex identification. The high incidence of peri-mortem fractures in individuals from formal graves and pit burials suggests conflict within the community and neighbouring groups that were competing for scarce resources. The osteological analysis focused on skeletal and dental markers of deprivation, traumas, degenerative conditions and pelvic changes possibly linked to reproduction. In addition, we present data from ${ }^{14} \mathrm{C}$ dating, tooth cementum annulation and $\delta^{13} \mathrm{C} / \delta^{15} \mathrm{~N}$ isotope analyses for selected individuals. The detailed examination of the archaeological context in conjunction with assessing and interpreting non-specific stress indicators and traumas revealed a rich and complex picture of social differentiation at Early Bronze Age Schleinbach, in which conflict, abuse and marginalization played a decisive role.
\end{abstract}

\section{Keywords}

Early Bronze Age, Austria, Schleinbach, social relations, stress, deprivation, trauma, violence, conflict.

Zusammenfassung - Soziale Beziehungen, Entbehrung und Gewalt in Schleinbach, Niederösterreich. Ergebnisse einer interdisziplinären Analyse der frübbronzezeitlichen menschlichen Skelettreste

Die interdisziplinäre Analyse der Skelettreste von 63 Individuen aus den Gräbern und der Siedlung von Schleinbach in Niederösterreich brachte neue Erkenntnisse zu sozialen Beziehungen, allgemeinen Belastungszeichen und traumatischen Veränderungen in der frühen Bronzezeit. Die Individuen wurden in zwei Gruppen formeller Gräber sowie in ehemaligen Speichergruben beigesetzt. Die mitochondriale DNA-Analyse identifizierte genetische Beziehungen zwischen zwei Personen, die in einem Doppelgrab eng beieinanderliegend bestattet wurden, sowie zwischen Personen aus einer Mehrfachbestattung. Das Geschlecht von vier Kindern, die im Kontext mit Gewaltevidenz begraben waren, wurde durch proteomische Geschlechtsidentifikation bestimmt. Das gehäufte Vorkommen perimortaler Frakturen bei Individuen aus formellen Gräbern und Grubenbestattungen deutet auf Konflikte innerhalb der Gemeinschaft und zwischen benachbarten Gruppen hin, die 
im Wettbewerb um knappe Ressourcen standen. Die osteologische Analyse konzentrierte sich auf Entbehrungszeichen am Skelett und an den Zähnen, Traumata und degenerative Veränderungen sowie Beckenveränderungen, die möglicherweise mit speziellen Belastungen durch Schwangerschaften und Geburten in Verbindung stehen. Darüber hinaus präsentieren wir Daten $\operatorname{der}{ }^{14} \mathrm{C}$-Datierung, Zahnzementanalyse und $\delta^{13} \mathrm{C} / \delta^{15} \mathrm{~N}$-Isotopenanalysen für ausgewählte Personen. Die detaillierte Untersuchung des archäologischen Kontextes in Verbindung mit der Bewertung und Interpretation von Stress- und Belastungszeichen und Traumata ergab ein reiches und komplexes Bild sozialer Differenzierung im frühbronzezeitlichen Schleinbach, in dem Konflikte, Misshandlungen und Marginalisierung eine entscheidende Rolle spielten.

\section{Schlüsselbegriffe}

Frühbronzezeit, Österreich, Schleinbach, soziale Beziehungen, Entbehrung, Trauma, Gewalt, Konflikt.

\section{Introduction: Archaeological and Historical Background of the Materials}

Few skeletal collections have such a colourful excavation, storage and assessment history as the remains of over 60 individuals from 36 graves and nine pits at the Early Bronze Age site of Schleinbach. ${ }^{1}$ The burial of an adult male with three children and the double burial of two individuals that were placed together in the grave made the site particularly well known beyond the borders of Austria. So far, however, a detailed, modern assessment of the entire skeletal material from this site has been lacking. We were able to integrate Schleinbach as a case study in the larger framework of the ERC-funded project 'The value of mothers to society', which aims to clarify the relationship between motherhood and women's social status. This approach, outlined in detail for the site of Unterhautzenthal, ${ }^{2}$ necessitates an interdisciplinary examination of the excavation context and a morphological assessment of the skeletal remains. A focus on changes in the pelvis and degenerative or pathological conditions in the surrounding bone elements aims to reveal the physical burden of pregnancies and childbirth events. Moreover, we investigate signs of deprivation and indicators of violence from traumatic lesions in this group and discuss their social framework. We conducted ${ }^{14} \mathrm{C}$ dating, tooth cementum annulation and $\delta^{13} \mathrm{C} / \delta^{15} \mathrm{~N}$ isotope analyses to acquire additional insights into details of the lives of selected individuals. The genetic relationship between the individuals from double burial 30/31 and burial pit 60 were tested by mtDNA analysis and the sex of the children from

1 The full catalogue of Bronze Age human remains from Schleinbach is available as an online Appendix: doi: 10.1553/ archaeologia104s13-A.

2 Rebay-Salisbury et al. 2018. burial pit 60 as well as $1981 /$ Grube 3 was revealed by proteomic analysis.

\subsection{Site, Excavation and Research History}

Schleinbach is located north of the Danube in Lower Austria, $10 \mathrm{~km}$ northeast of the city of Vienna. The 63 individuals under study are part of a cemetery and settlement complex of the Únětice Culture. The first finds were discovered in 1911 on the grounds of a brick factory, but systematic excavations by Karl Kriegler did not begin until 1926. The recovery strategy largely depended on clay extraction, with a considerable number of graves and settlement features destroyed without documentation. The Bronze Age settlement covered about 1.5 ha and might have been situated next to a prehistoric lake. ${ }^{3}$ Two distinct groups of Early Bronze Age burials are known: Group 1 in the western site area, and Group 2 in the east. Excavations of the 17 graves of Group 1 started in 1926. Double burial 30/31 came to light in 1927, and the quadruple burial of an adult male and three children in Pit 60 was excavated in 1931. The 14 graves of Group 2 were amongst the last contexts Kriegler excavated in $1940 / 41 .^{4}$

Kriegler recognized the importance of the finds, and exceptional for the time - arranged the en bloc preservation of burial 29, double burial 30/31, and quadruple burial 60 . It was an enormous undertaking to fix the skeletons in situ in the surrounding soil, mount them onto wooden boards, stabilize them with plaster and transport the blocks to the Lower Austrian Museum (at that time located at Herrengasse 9, 1010 Vienna) and the Anthropological Institute of the University of Vienna (Van Swietengasse 1, 1090 Vienna). In the museum, burials $30 / 31$ and 60 were presented to the public in a similar way as they were found in the field. They survived World War II in a room with broken windows on the second floor of the museum in Herrengasse. In 1950 and 1951 , some cleaning and conservation work was carried out, including the installation of a new glass cover, before the burials were put on display in the newly designed prehistoric exhibition. The prehistoric finds moved to the new $\mathrm{mu}-$ seum of prehistory in Asparn/Zaya in 1967 and remained on display until the redesign of the exhibition in 2013. They provisionally found a home in the storage facilities of the old tobacco factory in Hainburg, broken into pieces, before they were transported to the Natural History Museum in Vienna in 2017 in order to unite the skeletal remains from Schleinbach in the Department of Anthropology.

\footnotetext{
3 Weninger 1954a. - RetTenbacher 2004, 7.

4 Ret'tenbacher 2004, 8.

5 Rebay-Salisbury 2018 b.
} 

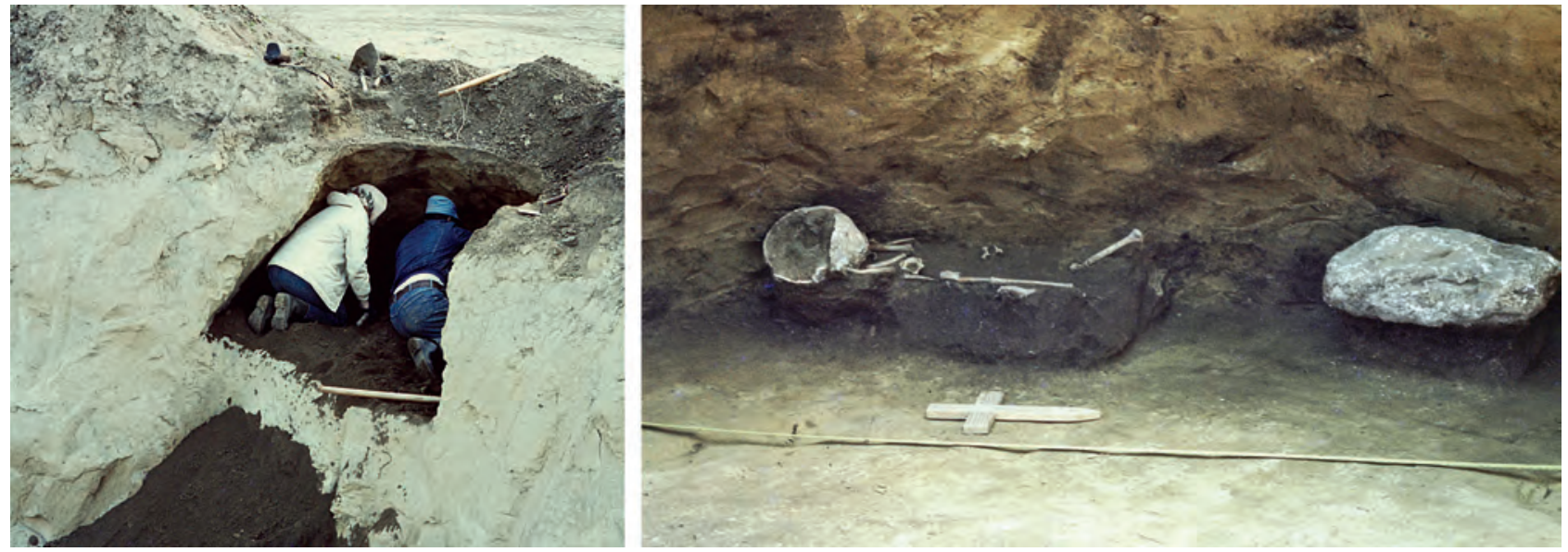

Fig. 1. Early Bronze Age cylindrical pit (Grube 3) with the remains of a 5-6-year-old child excavated in 1981 (Photos: H. Schwammenhöfer).

The focus on preservation and display of the most interesting contexts rendered the osteological analysis of the skeletal remains of secondary importance. Josef Weninger assessed the bones of the quadruple burial 60 after they had been mounted and remarked that the methodology had to be restricted to a morphological assessment and the measurement of the accessible bones. ${ }^{6}$ His published report included some very sophisticated observations regarding taphonomic formation processes within the burial pit, and a slightly shortened version was reprinted thirteen years later with less emphasis on racial aspects. ' In the same journal issue, Margarete Weninger published osteological observations on twelve individuals from Graves 9-18, 29 and Pit 56. ${ }^{8}$

As the clay extraction at Schleinbach continued, Hermann Schwammenhöfer resumed rescue excavations from 1981 to 1986, primarily documenting Late Neolithic and Early Bronze Age settlement finds. ${ }^{9}$ Human remains were found in some of the Early Bronze Age features. The partial and disarticulated skeleton of a 5-6-year-old child (1981/ Grube 3) with multiple impression fractures of the skull was found in a trapezoidal pit with a bottom diameter of c. $2.6 \mathrm{~m}$. The pit was preserved to a depth of c. $1.25 \mathrm{~m}$ and filled with dark, humus soil (Fig. 1). Finds in the fill include sherds, animal bones and a cylindrical clay weight. ${ }^{10}$

Another grave of a child (Grave 1981) was discovered and excavated by the Museum Stockerau. The body had been placed in a flexed position and was buried with

6 WeNinger 1941, 7.

7 Weninger 1954a.

8 WENINGER 1954b.

9 Schwammenhöfer 1982. - Schwammenhöfer 1986a. -SchwamMENHÖFER 1986b. - SCHWAMMENHÖFER 1987a. - SCHWAMMENHÖFER 1987b.

10 SChwammenhöfer 1982, 380. a ceramic vessel. ${ }^{11}$ The facial portion of the skull of an adult (1983/Grube 61) was recovered from a pit in 1983. Although within the area of a Neolithic house, the shape and contents of the pit, including ceramic sherds and animal bones, suggest an Early Bronze Age date. The trapezoidal pit was preserved to a depth of $1.30 \mathrm{~m}$ and its bottom diameter was $2.4 \mathrm{~m} .{ }^{12}$ The cranium and mandible of a $16-18$-yearold (1983/Grube 71) was found in the dark, humus-rich fill of a circular pit of $1.9 \mathrm{~m}$ diameter at the top and bottom and $0.75 \mathrm{~m}$ depth, alongside several large sherds of a storage vessel, animal bones, daub and a chert tool..$^{13}$

The contexts of Schleinbach found their way into many synthetic works on Austrian prehistory and the Bronze Age, ${ }^{14}$ but it was not until 2004 that the archaeological material of the Early Bronze Age settlement and cemetery was finally published, thanks to the efforts of Mirjam Rettenbacher. ${ }^{15}$ Rettenbacher only had access to J. and M. Weninger's initial anthropological assessment, ${ }^{16}$ which was biased by the excavator's intuitive judgement and partly incorrect. Maria Teschler-Nicola included the skeletal material held in the Natural History Museum at the time (Graves 9-18, Pit 56 and Grave 1981) in her habilitation thesis and came to different conclusions regarding the age and sex assessment. ${ }^{17}$ In this introduction and the archaeological analysis, we use the results of our re-examination of human remains detailed below.

11 Schwammenhöfer 1982, 390. - Teschler-Nicola 1992, 46.

12 SChwammenhöfer 1984, 244.

13 SChwammenhöFer 1984, 245.

14 Pittioni 1954, Fig. 211. - Lauermann 1992. - Neugebauer 1994. - Probst 1996. - Lauermann 2003, 507-510. - Probst 2011.

15 RetTenbacher 2004.

16 Weninger 1954a. - Weninger 1954b.

17 Teschler-Nicola 1992, 46-47. 
Today, the entire skeletal assemblage from Schleinbach, some of which has been collected for this study from the storage facilities in Hainburg, Korneuburg Museum, the Department of Anthropology of the University of Vienna and private collectors, is curated in the Department of Anthropology of the Natural History Museum in Vienna. We included all available remains from securely dated Early Bronze Age contexts in this study.

\subsection{Individuals and Cemetery Structure}

In total, skeletal remains of $62^{18}$ individuals from Schleinbach were available for osteological analysis, although some were represented only by isolated bones. The collection includes 14 adult and mature females over 20 (22.6\%), 15 adult and mature males $(24.2 \%)$ and six adult and mature individuals that could not be sexed $(9.7 \%)$. The 27 subadults under 20 years $(43.5 \%$ ) comprise one foetus/neonate of 7-8 lunar months gestational age, 12 children under 7 , five children between 7 and 14, and nine adolescents between 14 and 20, four of which were classified as females (Fig. 2). The low number of foetal/neonatal remains is probably a result of the antiquarian excavation techniques.

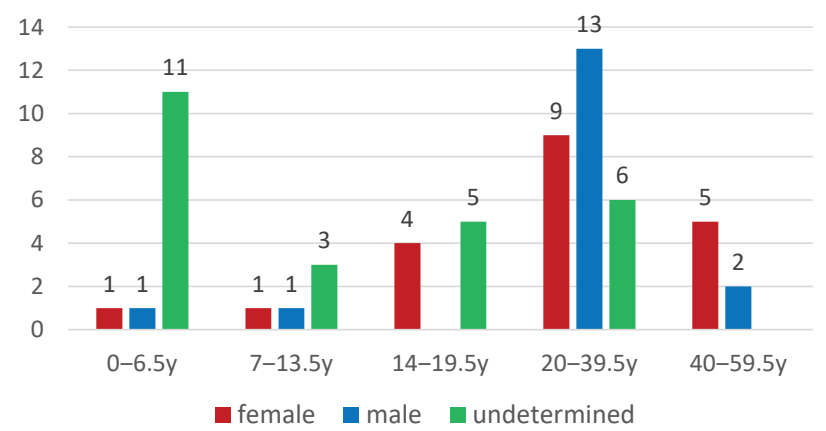

Fig. 2. Age and sex of the Early Bronze Age individuals buried at Schleinbach $(n=63$, including 55$)$.

The human remains were found in two distinct grave groups as well as buried or deposited in former storage pits and other features within the settlement.

Group 1 is composed of 18 individuals ${ }^{19}$ buried in 16 graves loosely arranged in two (perhaps three) rows along

18 No human remains are preserved from the disturbed Grave 113 or Pit 55. A photograph of the skeleton in Pit 55, however, clearly shows the incomplete epiphyseal closure of the distal ends of the femora. We therefore infer that an adolescent individual of 14-18 years was buried here.

19 Human remains of four individuals (1927/1-4) were not marked on the plan, but were recovered in the same year as individuals from Group 1; a geographical proximity is therefore likely.

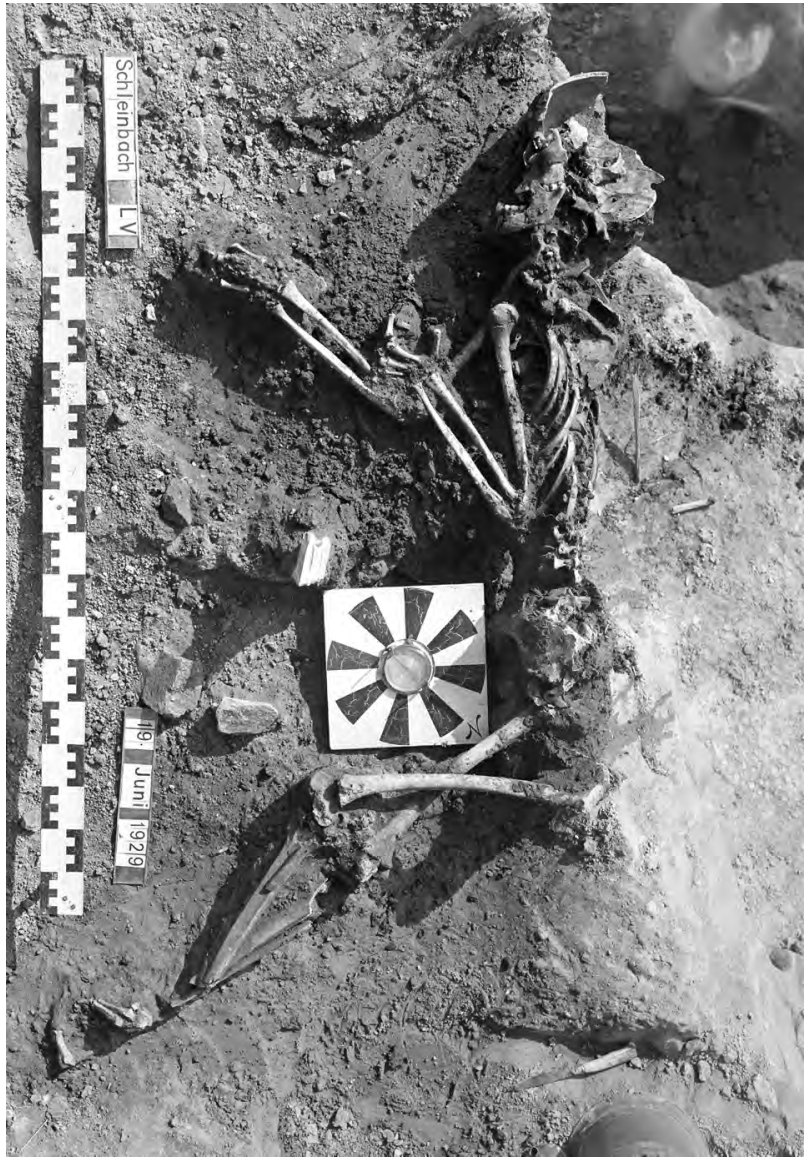

Fig. 3. Burial in Pit 55 (Photo: K. Kriegler 1929, ( $\odot$ Landessammlungen Niederösterreich, Bereich Ur- und Frühgeschichte, No. 17860).

a northwest-southeast axis (9AB, 10-18, 23, 27-31, 59). Eleven adults, seven females and four males, as well as seven subadults are part of this group. Cranial fragments and an upper incisor from a 1.5-year-old were found with the 45-55-year-old female in Grave 9, perhaps the remains of a co-buried young child. The individuals 30 and 31 , males aged $27-30$ and 30-35, were buried in close bodily contact in one grave pit. Individuals 15 and 18 were buried a little further apart from each other, but perhaps also in a common grave structure.

Pit 60 with the quadruple burial of an adult male with three children is located about $20 \mathrm{~m}$ west of Group 1. The child's Grave 22 was discovered nearby. Pit 32, about halfway between this feature and Group 1, contained a cranium and a femur from two females of different ages. Pit 63, about $20 \mathrm{~m}$ northeast of Group 1, also held cranial remains. Burials 55 (Fig. 3) and 56 (Fig. 4), about 25 m east of Group 1, appear to have been deposited in former storage pits. Kriegler's interpretations as 'pit, in which a creature died' and 'stoning 


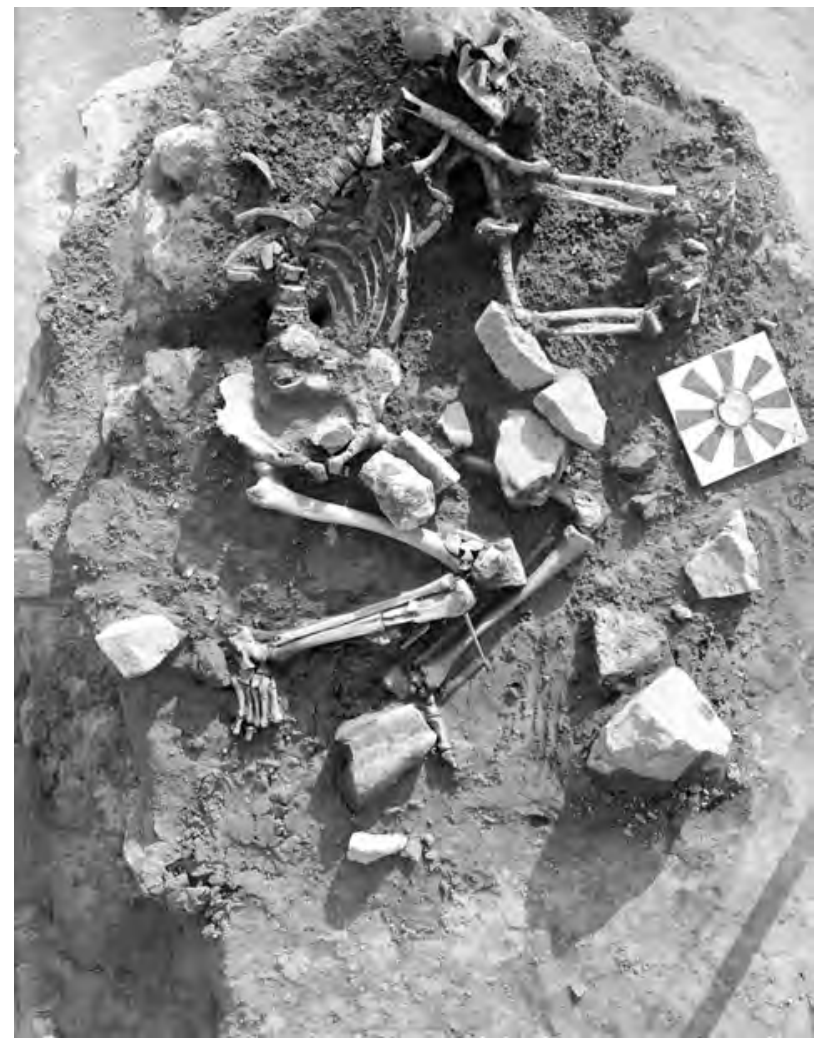

Fig. 4. Burial in Pit 56 (Photo: K. Kriegler 1929, (C) Landessammlungen Niederösterreich, Bereich Ur- und Frühgeschichte, No. 17871).

of an old woman'20 testify to the vivid imagination of the excavator.

Group 2 is located about $180 \mathrm{~m}$ southeast of the settlement and encompasses 14 graves (101-109, 111-115) and one pit (110), from which the skeletal remains of 23 individuals were recovered. The burials in this group were often found disturbed and the skeletons were disarticulated.

The group comprises two females and eight males over 20 as well as 13 individuals under 20, two of which were likely female $(106 / 1,112)$. The humerus of a foetus/neonate aged 7-8 lunar months (104/2) was found together with the remains of a 30-35-year-old female (104/1) and represents the youngest individual in the whole sample.

Graves 89 (with two crania), 90 and 91 were not found on the site map. The child's grave of 1981 had only postcranial remains preserved. Skeletal remains recovered from 1981 to 1983 could not be precisely located in relation to the other graves (Fig. 5).

20 RetTenbacher 2004, 83.

\subsection{Bronze Age Setting and Radiocarbon Chronology}

The small-scale communities that lived in eastern Austria north of the Danube during the Early Bronze Age ${ }^{21}$ belong to the Únětice cultural complex, distributed from Thuringia and Saxony via Bohemia and Moravia to Silesia, Slovakia and Lower Austria. Material remains from settlements, clusters of a few houses, testify to a farming lifestyle of growing crops and keeping animals. Few bronze objects were in circulation, but they appear to play a significant role in the economy and the development of social stratification. Both men and women were buried in a flexed position, placed on the right side of the body with the head in the south, in contrast to communities south of the Danube, in which gendered placement of bodies was the norm..$^{22}$ Bodies were buried in formal, single graves near the settlements, but also buried or disposed of in decommissioned storage pits. ${ }^{23}$ This post-mortem social differentiation is significant. Individuals buried in close contact, often referencing each other in the body positions, suggest social and family relationships. ${ }^{24}$

Samples from eight individuals from different contexts and groups were taken for AMS radiocarbon dating, which was performed at Beta Analytic on bone collagen extracted with alkali. Individuals were chosen to represent a wide range of contexts and for their association with datable material culture. Conventional Radiocarbon Ages (BP) were corrected for natural and laboratory-induced total isotopic fractionation effects and calibrated with BetaCal 3.21 using the INTCAL 2013 atmospheric reservoir database. ${ }^{25}$ Probable calendar dates fall between 2084-1627 calBC, a timespan of over 450 years (Tab. 1, Fig. 6). The shortest possible use of the cemetery is roughly 100 years (c. 1950-1850 BC), which seems most likely, given that graves plotting far from each other in radiocarbon years are actually located in close proximity to one another.

Comparing the radiocarbon dates to the typo-chronological framework, ${ }^{26}$ Grave 9 dates late in the Únětice development, based on the decorated disk-headed pin and the shape of the ceramic cup. Grave 12 also includes a cup considered late in the typological development. The multiple burial 60 is dated to the developed phase of the Únětice Culture primarily because of the pottery placed on top of the burial; no other radiocarbon-dated contexts contained material culture for comparison.

21 C. 2150-1700 BC, cf. Stockhammer et al. 2015.

22 E.g. at Franzhausen, Pottenbrunn and Gemeinlebarn: Bertemes 1989. - Neugebauer 1991. - Neugebauer, Neugebauer 1997. Blest 2006.

23 Neugebauer 1994. - Lauermann 2003.

24 Rebay-Salisbury 2018a.

25 Reimer et al. 2013.

26 Rettenbacher 2004, 55-56. 


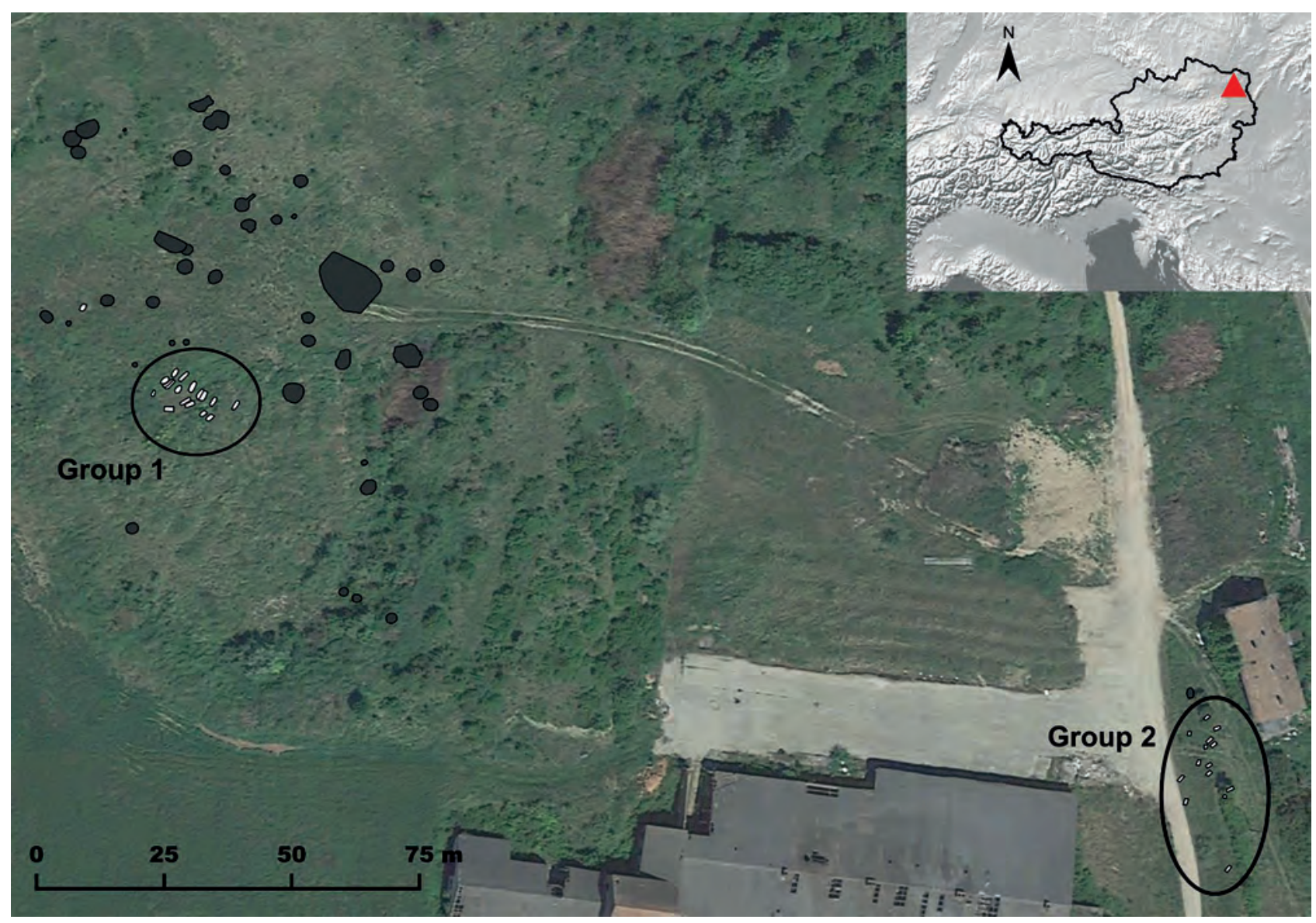

Fig. 5. Schleinbach site map. - Bronze Age pits and graves, including grave groups 1 and 2 (Base map: Google Maps, @ 2015 Google; satellite image provided by QuickMapsServices, ( 2019 DigitalGlobe; figure: R. B. Salisbury).

\begin{tabular}{|l|l|l|l|l|l|}
\hline Beta no. & Individual & Sex & Age & Conventional age & Calendar calibration (probability) \\
\hline 490671 & $9 \mathrm{~A}($ Group 1$)$ & female & $45-55$ years & $3410 \pm 30 \mathrm{BP}$ & $1773-1627$ calBC $(93.1 \%) 1865-1849 \mathrm{calBC}(2.3 \%)$ \\
\hline 490672 & $12($ Group 1$)$ & - & $5-6$ years & $3480 \pm 30 \mathrm{BP}$ & $1888-1737$ calBC $(90.9 \%) 1715-1697 \mathrm{calBC}(4.5 \%)$ \\
\hline 490673 & 22 & - & $3.5-4.5$ years & $3610 \pm 30 \mathrm{BP}$ & $2036-1889 \mathrm{calBC}(94.9 \%)$ \\
\hline 494944 & 30 (Group 1) & male & $27-30$ years & $3640 \pm 30 \mathrm{BP}$ & $2056-1921$ calBC $(79.6 \%) 2133-2084 \mathrm{calBC}(15.8 \%)$ \\
\hline 490674 & $60 \mathrm{C}$ (multiple burial) & - & $3-4$ years & $3500 \pm 30 \mathrm{BP}$ & $1906-1743 \mathrm{calBC}(95.4 \%)$ \\
\hline 494945 & $1927 / 1$ & female & $18-21$ years & $3550 \pm 30 \mathrm{BP}$ & $1976-1861 \mathrm{calBC}(67.7 \%) 1853-1772 \mathrm{calBC}(26.9 \%)$ \\
\hline
\end{tabular}

Tab. 1. Radiocarbon dates of six individuals from Schleinbach (submitted samples of individuals 104/1 and 109 were too contaminated to produce reliable results).

\subsection{Burial Practices}

Bodies buried in simple grave pits are usually found placed on their right side, with arms bent in front of the body and legs loosely to extremely flexed $(n=18)$. The three individuals found on their left side were buried in pits (56, 60A, 60B). The supine position, which was used for individuals 60 and $60 \mathrm{~B}$ in a pit and the individuals in double burial $30 / 31$, is unusual.
The shape and measurements of the grave pits were only recorded in a few cases, but data on the depth of graves is available for 29 graves. The shallowest grave was found at $0.15 \mathrm{~m}$ depth, the deepest at $1.6 \mathrm{~m}$, and on average graves were $0.86 \mathrm{~m}$ deep. Women were buried in graves with an average depth of $0.83 \mathrm{~m}$, whereas men averaged $0.99 \mathrm{~m}$; individuals under 20 years were buried in graves of $0.83 \mathrm{~m}$ depth, and those over 20 years at $0.92 \mathrm{~m}$ depth. Age and 


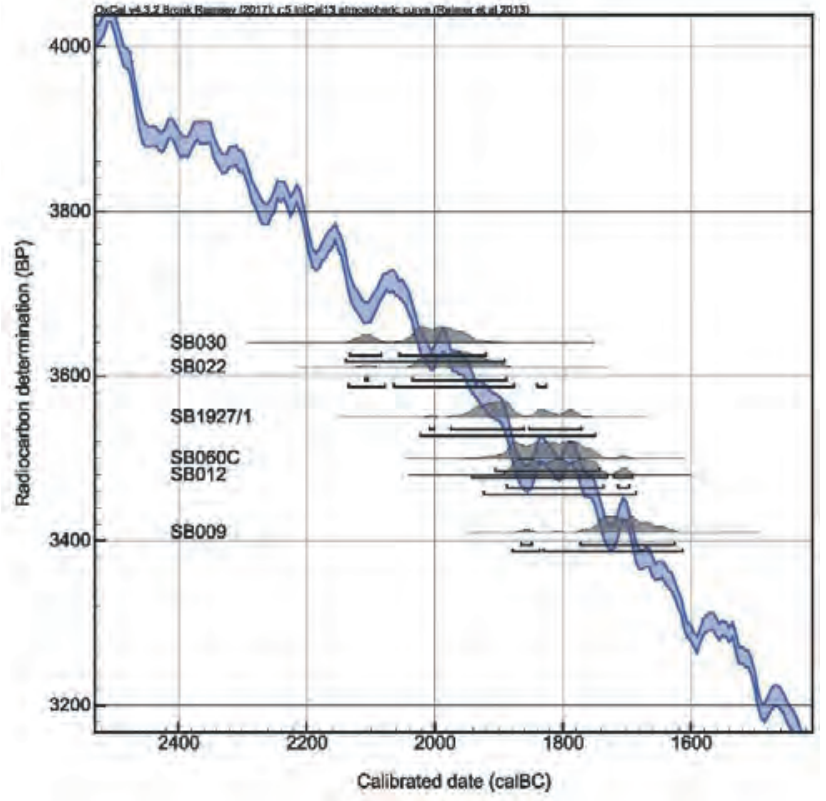

Fig. 6. Curve plot from OxCal 4.3 (https://c14.arch.ox.ac.uk/ oxcal/OxCal.html).

gender differences such as these have been observed in other cemeteries such as Unterhautzenthal. ${ }^{27}$

A sketch of the cemetery plan ${ }^{28}$ suggests all individuals from Group 1 and Child 22 were placed in a southwest-northeast orientation; the placement of the bodies in Group 2 and within the settlement is less clear. Pit burial 55, the grave of a 14-18-year-old, followed the regular conventions (right body side, southwest-northeast orientations).

The double burial of the two male individuals 30 and 31 (Fig. 7), who died at the ages of 27-30 and 30-35 years, most likely as a result of skull fractures, were placed very close together in a single grave pit. The bones of the feet overlapped (30 over 31 ) and the pelvic bones almost touch, giving rise to the suspicion that they were bound or wrapped together after death. ${ }^{29}$ The kneecaps in anatomical position suggest minimal movement and covering with soil after deposition. The individual on the right, older and more robust, had his left humerus parallel to the body, the elbow was bent at about a right angle so that the lower arm came to rest across the body. The right upper arm, however, slightly overlay the individual on the left (31 over 30 ) and was bent so that the right hand came to rest on his own neck; the skull may have turned towards the right as part of post-depositional

27 Rebay-Salisbury et al. 2018.

28 WENINGER 1954a, 2.

29 WENINGER 1954b, 58.

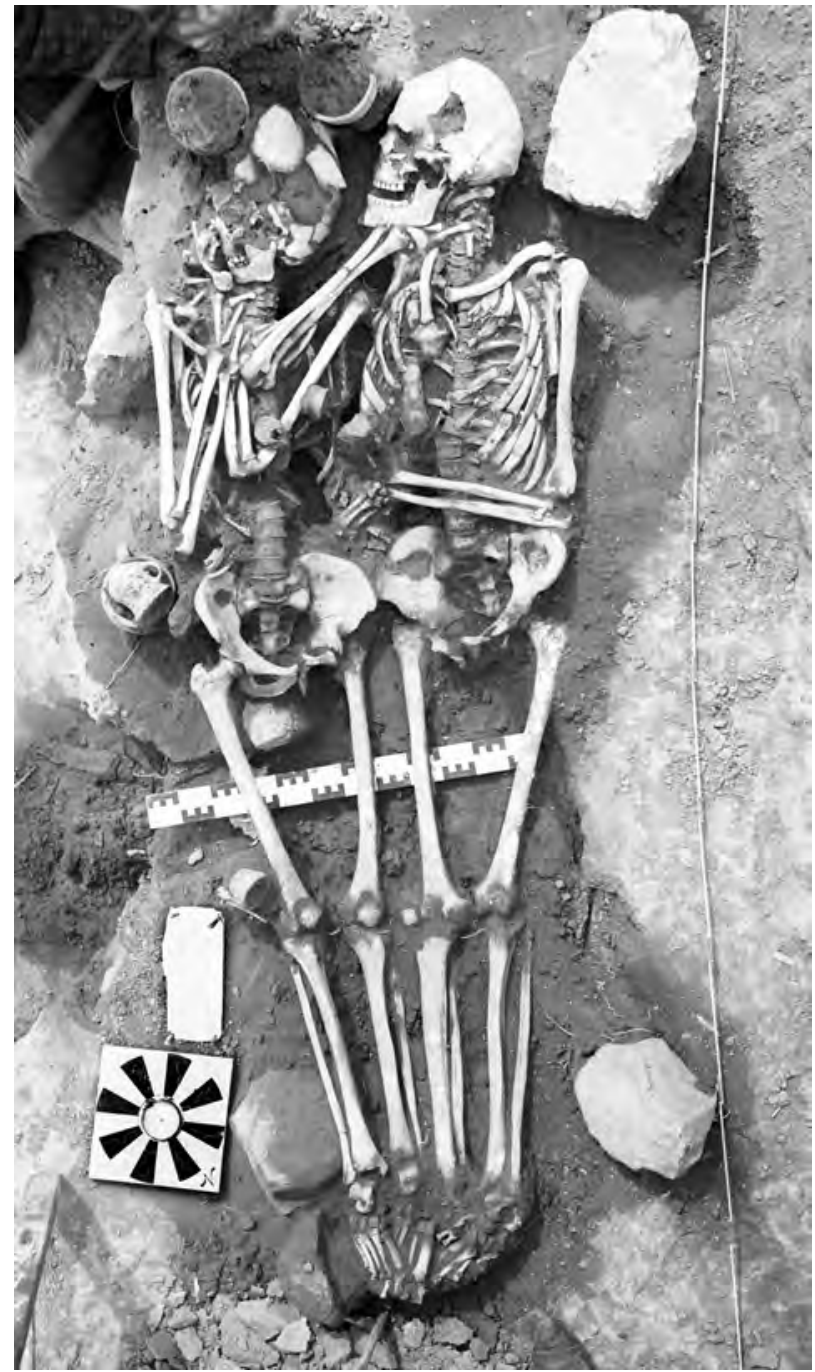

Fig. 7. The male individuals 30 (27-30 years) and 31 ( $30-35$ years) buried together (Photo: K. Kriegler, ( $)$ Landessammlungen Niederösterreich, Bereich Ur- und Frühgeschichte, No. 17885).

processes. The left, younger and more gracile male, who was originally thought to be a female, had both arms folded on the chest. Again, the hands came to rest near the neck. The skull was found fractured, but the position of the cervical vertebrae suggests that the head had been turned towards the right upon deposition.

Pit 60, a circular structure of $1.4 \mathrm{~m}$ depth, contained the quadruple burial of an adult man (60) and three children (Fig. 8). Individual 60A, an 8-9-year-old child of about 120$124 \mathrm{~cm}$ in height, was found on the left body side, oriented north-northeast/south-southwest, with flexed arms in front of the upper body, and flexed legs, the left one bent more towards the upper body than the right one. Individual 60B, approximately 12 years old based on the dental status, but probably only $115-119 \mathrm{~cm}$ tall, was found with the upper 


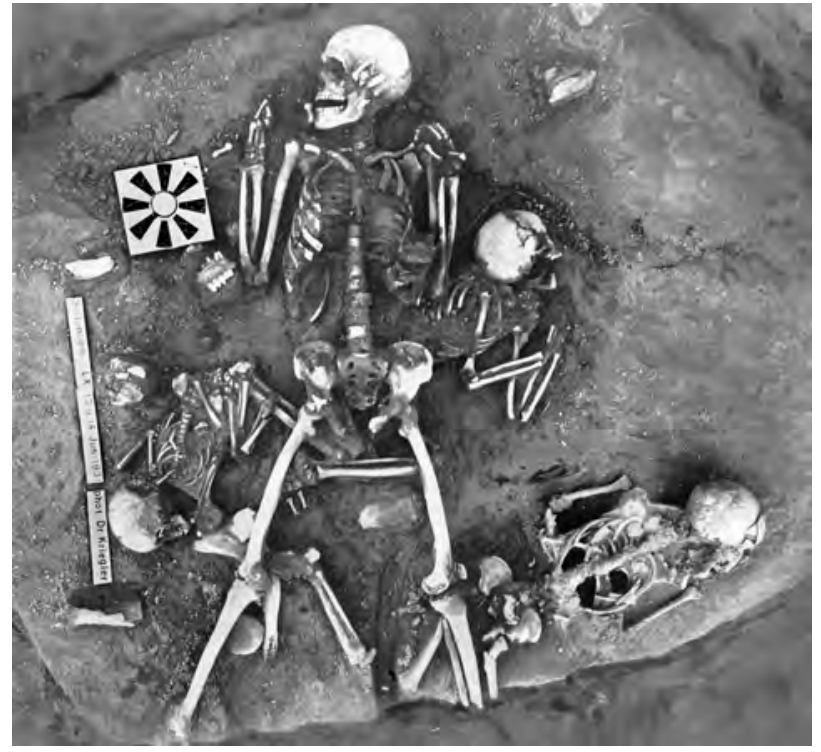

Fig. 8. Burial of an adult male (30-35 years) with three children, 3-4, 8-9 and c. 12 years at death (Photo: K. Kriegler, ( ) Landessammlungen Niederösterreich, Bereich Ur- und Frühgeschichte, No. 17883).

body in an extended position, oriented northeast-southwest, with flexed legs tilted to the left. The right arm is bent at $90^{\circ}$ and placed over the body; the left lower arm and lower leg were truncated during excavation. The 30-35-year-old adult male 60 was placed directly on top of both children. There was no soil separating the skeletons, suggesting a single depositional event - a multiple rather than collective grave. He lay in an extended position, with a northwest-southeast orientation, and with legs slightly opened at about $35^{\circ}$. The left lower leg is damaged and the feet are missing. The spine of child 60A came to lie just under the spine of the adult and provided a barrier, which caused a specific break at the thoracolumbar junction. His humeri were found parallel to the upper body, elbows were bent and the hands were found next to the shoulders. This unusual body position has led to his nickname 'the priest' (given by Kriegler). We found the cervical vertebrae in a straight position when we lifted the skull. Since they had not rotated to turn the head while it was still articulated, we can infer that the skull fell towards the right side after the soft tissues had decomposed. Originally, the head was facing straight when it was buried. Individual 60C, a 3-4-year-old child of 75-79 cm height with an unhealed peri-mortem impression fracture of the left parietal bone was the only one placed according to the burial customs of the community, on the right side with flexed legs, in a southeast-northwest orientation. The stratigraphic position over the legs of child 60A suggests it was placed in the pit after this child, but it is unclear if it was deposited before or after the adult, as they do not seem to overlap directly. ${ }^{30}$

It had been noted during the excavation that the rib cages of the adult and children A and B were extraordinarily well, three-dimensionally preserved. The excavator Kriegler interpreted this fact as an indication of artificial body preservation such as mummification. J. Weninger, however, drew a more likely conclusion, namely that after the decomposition of soft tissue, the rib cage must have been filled by 'fortunate soil filling'. ${ }^{31} \mathrm{He}$ also noted that the children's skulls were turned backwards in relation to the body axes, which some observers interpreted as a sign of a violent death. Weninger suggested that this effect might be explained by water entering the grave, causing the light skulls to float. ${ }^{32}$

In light of the principles of archaeothanatology, ${ }^{33}$ we can suggest that the bodies were placed in a pit - presumably an old storage pit - and initially composed in a void. The pit may have been covered, since no traces of rodent gnawing were discovered. The open legs of the adult and older children suggest that the lower bodies had not been bound or restrained by textiles such as shrouds; they were either naked or covered by loose clothing. No bronze dress elements nor traces thereof as stains on the bones were found; only a few animal bones and the fragment of a ceramic vessel were recovered at the level of the bodies. During the decomposition process, gravity caused the skulls to fall backwards and/or rotate. Some bones, such as the right radius of individual $60 \mathrm{~B}$, might have moved due to bioturbation. After the decomposition of soft tissue, the void was filled by fine sediment - loess -, which was probably washed into the pit with precipitation. Two complete Early Bronze Age jugs were found on top of the burials, separated by about a metre of fill. ${ }^{34}$

\subsection{Material Culture}

Many artefacts originally found with the bodies from Schleinbach and mentioned in Kriegler's protocols have subsequently been lost. Rettenbacher described and analysed all available finds in detail ${ }^{35}$ some observations on age and gender associations therefore suffice here.

Bronze dress pins - Scheibenkopfnadeln, a Rollenkopfnadel and pin fragments - were found in six graves, those of a 3-4-year-old (105) and a 10-12-year-old child (10), a 14-15-year-old (17), and three graves of mature women

\footnotetext{
30 Weninger 1941, Pl. 2, Fig. 2.

31 WeNinger 1954a, 4.

32 Weninger 1954a, 26.

33 Duday 2006. - Duday 2009.

34 Cf. Rebay-Salisbury 2018 b.

35 RetTenbacher 2004.
} 
$(9,11,107)$. A bronze sewing needle was found with a 13-15-year-old (13).

An Ösenhalsreif neck ring was found with individual 101/1, a 14-16-year-old, and mentioned in connection with the 14-15-year-old possible female in Grave 17. Spiralröllchen necklace components are primarily found in the graves of women of different ages (3-4-year-old in Grave 105, 14-16-year-old in Grave 101, 15-21-year-old in Grave 112, 30-35-year-old in Grave 104, 45-55-year-olds in Graves 9 and 11).

The c. 4-year-old child in Grave 22 had an arm ring on the right wrist. A pair of cast arm rings were part of the grave good assemblage of the 12-14-year-old in Grave 10. A child's arm ring was further mentioned in context with the mature female in Grave 11, labelled as not part of the grave set.

Noppenringe are amongst the most common pieces of jewellery. Sets were found in three graves of subadults (10-12-year-old in Grave 10, 13-15-year-old in Grave 13, 14-15-year-old female? in Grave 17) and three adult/mature women (30-35, Grave 104; 45-55, Graves 9 and 11). A single Noppenring was associated with the 25-35-year-old adult male in Grave 103.

Bone pins and awls are relatively common finds. They were found with a 10-12-year-old in Grave 10, the adult males in double burial 30/31 and a 21-25-year-old male in Grave 15, as well as three females (30-35-year-old in Grave 18, 21-25-year-old in Grave 16, 30-35-year-old in Grave 104).

Mollusc jewellery was found in the form of Dentalium pendants in Grave 112 (15-21-year-old, perhaps female) and in the form of shells in Grave 10 (10-12-year-old). A bone disc with a central hole was discovered in Grave 17, near the skull of a 14-15-year-old, possibly female individual. The bone ring discovered in Grave 109 most likely belonged to the 30-40-year-old male, and not to the 2-3-year-old child represented by a cranium in the same grave.

Chipped stone artefacts were also common and were found with ten individuals - both males and females from the age of 12 . Noteworthy is the flint saw, discovered in Grave 9, the burial of a 45-55-year-old female and a 1.5-year-old child.

Pottery was found with 28 of the 64 individuals and was most often deposited as the typical Early Bronze Age set of cup, bowl and jug. Positions near the head, in front of the body or towards the feet have been recorded. Large vessel fragments were part of the fill of pits. Seven graves contained animal bones, likely primarily from sheep/goat and cattle. Their specific placement within the graves suggests they were part of a meat provision. ${ }^{36}$

\subsection{Grave Disturbance and Reconstructed Grave Goods}

The secondary reopening of graves, the manipulation of the skeletal remains and object removal was common in the Moravian-Austrian area of the Únětice Culture ${ }^{37}$ and in Lower Austria south of the Danube. ${ }^{38}$ At Schleinbach, there are significant differences within the cemetery as to the extent of grave robbing.

Group 1 in the northwestern area includes 18 buried individuals, some of which remained undisturbed $(10,13$, $29,30,31)$, some were slightly disturbed (14-17) with some body parts, such as the legs, remaining in situ, and one was contracted to a bone pack (9A). The child in Grave 22 buried between Group 1 and Pit 60 was left in peace. The individuals of Pit 60 likewise do not seem to have been moved by human manipulation after decomposition and before they were discovered. The two pit burials, 55 and 56, held bodies in full articulation. Graves 89, 90 and 91 were disturbed (89B perhaps acquired the second skull of a female $89 \mathrm{~A}$ in the process), but the body placement and orientation remained evident.

In Group 2, only 2 of the 23 individuals $(104 / 1,105)$ appear undisturbed; many individuals were found completely disarticulated, such as Graves 107-109, 111 and 112. The majority are hard to assess, as no photographs are available. Grave 115 contained an articulated postcranial skeleton of a 30-39-year-old male, but the skull is missing.

We recorded the anatomical location of green stains on the bones of the skeletons that likely stem from copper salts from bronze grave goods, compared them to the objects found in the graves, and reconstructed missing grave goods for the social status analysis. ${ }^{39}$

Of the 14 individuals associated with bronzes, 12 showed green stains on the bones that could be explained by the still present grave goods (9A, 10,11,13, 14, 17, 22, 101/1, 104/1, 105, 107, 112). The individuals from Graves 103 and 106 were likely not in contact with the bronze fragments recorded in their graves. Grave 14, that of a 15-18-year-old with stains on the left zygomatic process, the left clavicle, the left scapula and both radii and ulnae, is likely to have had more jewellery than the recorded ' $3 \mathrm{~mm}$ bronze wire in pin diameter'. ${ }^{40}$

Green staining of the bones was observed in nine individuals (Tab. 2) whose graves did not contain any bronzes upon excavation. Particularly intriguing is the individual in Grave 12, a 5-6-year-old child, which appeared undisturbed.

\footnotetext{
37 STUCHLÍK 1990, 165.

38 SPRENGER 1999.

39 Cf. Sprenger 1999.

40 Ret'tenbacher 2004, 75.
} 


\begin{tabular}{|c|c|c|l|}
\hline Individual & Sex & Age & \multicolumn{1}{|c|}{ Location of green stains } \\
\hline 12 & - & $5-6$ & $\begin{array}{l}\text { left side of the viscerocranium (glabella, nasal bone, maxilla, zygomatic bone) and right ramus } \\
\text { mandibulae; right clavicle, right scapula and proximal portion of right humerus; right first rib; } \\
\text { phalanges of the right hand }\end{array}$ \\
\hline 16 & female? & $21-25$ & left temporal bone \\
\hline 18 & female? & $30-35$ & left temporal bone, one cervical vertebra, ribs (?) \\
\hline $89 \mathrm{~A}$ & female & $30-45$ & $\begin{array}{l}\text { right parietal, temporal and occipital bone; skull base, right maxilla, right zygomatic bone; all present } \\
\text { cervical vertebrae }\end{array}$ \\
\hline $89 \mathrm{~B}$ & male & $25-30$ & $\begin{array}{l}\text { right parietal, temporal and occipital bone; both zygomatic processes, right side of the mandible, } \\
5-7^{\text {th }} \text { cervical vertebrae and first thoracic vertebra; right clavicle and scapula; some metacarpals and } \\
\text { phalanges of the right hand }\end{array}$ \\
\hline 90 & female & $27-35$ & thoracic vertebrae, carpals and metacarpals of the right hand \\
\hline $103 / 3$ & - & $14-20$ & distal femur shaft \\
\hline $106 / 2$ & - & $20-40$ & lumbar vertebrae, phalanges of the right hand \\
\hline 110 & female? & $20-40$ & ribs, cervical vertebrae fragments \\
\hline
\end{tabular}

Tab. 2. Sex, age and location of green stains for individuals from Schleinbach not associated with bronze grave goods.

The discolorations of the bones suggest that jewellery must have been present in the head, neck, chest and finger regions.

Stains to the temporal regions of the skull suggest Noppenringe hair ornaments $(12,16,18,89 \mathrm{~A}, 89 \mathrm{~A}, 89 \mathrm{~B})$. The extra female skull discovered in Grave 89 probably came from a rich woman's grave, equipped with hair and neck jewellery. The male in the same grave was most likely originally laid into the grave with a Noppenring and at least a dress pin, perhaps also a neck ring. Stains on the cervical vertebrae, such as in the individual from Pit 110, suggest neck jewellery; green discolouration of finger bones points to finger rings or bracelets $(12,89 \mathrm{~B}, 90,106 / 2)$. Other stains in a-typical body regions may be traced to unrecovered bronze fragments dislocated in the grave reopening process.

\subsection{Social Status}

A social status assessment of individuals from Schleinbach is hindered by the site's very incomplete excavation, documentation and artefact recovery. In addition, the level of (contemporary?) grave reopening and artefact removal was high. It is therefore not possible to follow the more detailed social index methodology used at Unterhautzenthal ${ }^{41}$ or Franzhausen I. ${ }^{42}$ Despite the limitations of the data, a coarse classification into 'rich', 'average' and 'poor' graves enables a comparison of the social treatment of the dead with pathological conditions noted in their skeletal remains. We base the classification on the following criteria:

- rich: two or more types of material culture, evidence for a set of bronze dress elements and jewellery (including inferred by green discolorations on bones)

41 Rebay-Salisbury et al. 2018.

42 Sprenger 1999.
- average: pottery vessels, but no evidence of bronze assemblages (beyond single rings or fragments, no significant green stains)

- poor: no evidence of bronze goods, no green stains, no pottery vessels (but some pottery fragments in the fill). Almost all of the 13 'rich' individuals are part of Group 1 (9$14,17,18)$. Only two of Group $2(101 / 1,112)$, as well as 89B and 90 , fall in this category. Importantly, all 'rich' individuals are buried in graves. The 5-6-year-old from Grave 12 is the youngest afforded an individual grave of this category; two older children (10-12 years from Grave 10 and 1315 years from Grave 13), four adolescents $(14,17,101 / 1$ and $112)$, three adults between 20 and 40 years $(18,89 \mathrm{~B}, 90)$ and two mature individuals between 45 and 55 years $(9 \mathrm{~A}, 11)$ are further in the group of 'rich' burials. Group 1 includes seven (probably) female individuals, but only one male (89B).

Of the 19 individuals rated 'average', seven were buried in Group 1 (15, 16, 23, 27, 29-31), nine in Group 2 (102, $103 / 1,104 / 1,105,106 / 1,106 / 2,107,113,114)$ and three (22, $89 \mathrm{~A}, 1981)$ off the cemetery groups. All were again found in graves. Group 1 includes five children (c. 1, 3-4, 3.5-4.5, 6-7, 7.5-9 years old), but only one adolescent (the female 16-20-year-old from Grave 106). Eleven adults aged between 20 and 40 and one mature woman aged 40-60 were rated as buried with an average grave good assemblage. Six (probably) female and six (probably) male individuals make for an even gender balance.

The group of the 32 'poor' individuals comprises only two from Group 1 (28, 59), 12 from Group 2 (101/2, 101/3, 103/2, 103/3, 103B, 104/2, 104/3, 108, 109/1, 109/2, 111, 115 ) and Grave 91. It is noteworthy that most complete burials in storage pits $(55,56,60,60 \mathrm{~A}, 60 \mathrm{~B}, 60 \mathrm{C}, 110)$ and human remains found in storage pits $(32 / 1,32 / 2,63,1927 / 1-4$, 
1981/Grube 3, 1983/Grube 61, 1983/Grube 71) do not include grave goods clearly associated with the individuals. The group of 'poor' burials includes one foetus/neonate, six young (0.3-6 years) and three older (7-13 years) children, four adolescents (14-20-years old), 11 adults aged between 20 and 40 and seven adults over 40 years, amongst which five were identified as female and nine as male.

The 40-55-year-old female from Pit 56, originally described as the 'stoning of an old woman' by Kriegler ${ }^{43}$ was indeed found lined and partly covered with stones (Fig. 4). The list of her pathological conditions is impressive and includes multiple healed and partly healed fractures, degenerative changes, sinusitis, periostitis, and poor dental health. This individual embodies ambiguity in the way she was treated: as one of the oldest individuals in the community, she must have received care and help from other members of the community ${ }^{44}$ during the healing of her sacrum and forearm fractures. However, the combination of the absence of grave goods, burial in a storage pit, and multiple fractures indicative of hard life experiences, accidents and/or interpersonal violence may indicate a rather low status within the community.

\begin{tabular}{|l|c|c|c|c|c|c|}
\hline & \multicolumn{2}{|c|}{ Rich } & \multicolumn{2}{c|}{ Average } & \multicolumn{2}{c|}{ Poor } \\
\hline Female & 7 & $39 \%$ & 6 & $33 \%$ & 5 & $28 \%$ \\
\hline Male & 1 & $6 \%$ & 6 & $38 \%$ & 9 & $56 \%$ \\
\hline Undetermined & 5 & $17 \%$ & 7 & $23 \%$ & 18 & $60 \%$ \\
\hline 0-6 years & 2 & $15 \%$ & 4 & $31 \%$ & 7 & $54 \%$ \\
\hline 7-13 years & 2 & $33 \%$ & 1 & $17 \%$ & 3 & $50 \%$ \\
\hline $14-20$ years & 4 & $44 \%$ & 1 & $11 \%$ & 4 & $44 \%$ \\
\hline 20-40 years & 3 & $12 \%$ & 12 & $46 \%$ & 11 & $42 \%$ \\
\hline $40-60$ years & 2 & $20 \%$ & 1 & $10 \%$ & 7 & $70 \%$ \\
\hline All & 13 & $20 \%$ & 19 & $30 \%$ & 32 & $50 \%$ \\
\hline
\end{tabular}

Tab. 3. Gender- and age-related trends of status distribution at Schleinbach $(\mathrm{n}=64)$.

Table 3 summarizes gender- and age-related trends. Overall, 13 (20\%) of all individuals are classified as 'rich', $19(30 \%)$ as 'average' and $32(50 \%)$ as 'poor'. That women appear richer in the burial record than men is primarily due to their gender-typical dress and jewellery. It is nevertheless noteworthy that a majority of women are afforded a 'rich'

43 Ret'tenbacher 2004, 27.

44 Tilley 2017. grave, and very few are in the group of 'poor' individuals, whereas with men it is the opposite.

The age structure of the distribution suggests an increase in a person's value from childhood through adolescence. 14-20-year-olds have the highest likelihood of having a well-equipped grave, especially if they are female. The trend tapers off in adulthood, when individuals are most likely to have an average burial. In old age, few individuals receive 'rich' or 'average' burials, more than two-thirds are buried in the 'poor' category.

\section{Methods}

\subsection{Osteology}

The methods used to assess age and sex, health aspects and trauma by the morphology of the human remains follow standard protocols and are outlined in detail in the context of our Early Bronze Age case study Unterhautzenthal. ${ }^{45}$ For estimating body stature and height, the maximum length of the femora ${ }^{46}$ was used to calculate the body height of individuals from Schleinbach. ${ }^{47}$ Only 13 individuals had complete femora preserved (9A, 11, 14, 15, 29, 30, 31, 60, $90,104 / 1,108,106 / 1,109 / 1)$. The stature of four additional adult/mature individuals and 12 subadults was reconstructed using other long bone measurements. ${ }^{48}$ When possible with respect to group size, the best preserved individuals were tested for significant differences with SPSS version 23. Calculations were performed between adult individuals buried in graves, and those buried in storage or settlement

45 Rebay-Salisbury et al. 2018, with further references. Methods of ageing adults are based on dental abrasion, changes at the pubic symphysis, fusion of endo- and ectocranial sutures, changes in the sternal joint surface of the clavicle and epiphyseal fusion. Bone length measurements, tooth eruption patterns and epiphyseal fusion are taken into account for children. Methods of sexing include a macroscopic assessment of the following features: Cranium: glabellar region, superciliary arch, frontal and parietal eminence, frontal inclination, mastoid process, zygomatic process, relief of nuchal plane, external occipital protuberance, zygomatic process, zygomatic bone, supraorbital margin, shape of orbits; Mandible: total aspect, mental eminence, mandibular angle, inferior margin; Pelvis: preauricular sulcus, greater sciatic notch, subpubic angle, arc composé, complete pelvis, obturator foramen, body of ischium, iliac crest, iliac fossa, greater pelvis, acetabular fossa/femoral head; Long bones: robusticity of humerus and femur. Characteristic features were graded between +2 (definitely male) and -2 (definitely female) and weighted according to their relevance. Pelvic features were given more weight than cranial features. Adapted i.a. from Acsádi, Nemeskéri 1970. - Bass 1971. - FazeKas, Kósa 1978. - Lovejoy et al. 1985. - Szilvassy 1988. Buikstra, UbeLAKer 1994. - BRŮŽEK 2002. - Lewis 2007. - White, Black, Folkens 2012. - Cunningham, Scheuer, Black 2016.

46 FE 1: Martin, Saller 1957.

47 Ruff et al. 2012.

48 Breitinger 1937. - Bach 1965. 
pits ('others', total $\mathrm{N}=20$; 9 females, 11 males; graves: males $15,108,109 / 1$, females 9A, 11, 14, 29, 104/1, 106/1, 107; others: males 30, 31, 60, 89B, 115, 1927/2; females 32/2, 56, 90, 1927/1).

Traumatic lesions on the skeletons from Schleinbach were systematically recorded. ${ }^{49}$ With the aim of revealing interpersonal violence in this group, we differentiated ante-, peri- and post-mortem lesions. By definition, peri-mortem fractures occur around the time of death, and it cannot be determined whether the individual was alive or dead at that point. No signs of healing are present and specific breakage patterns point to the presence of collagen and elastin in the bones. ${ }^{50}$

The recording of health aspects focused on skeletal and dental markers of deprivation. These include non-specific indicators of stress (porotic hyperostosis, cribra orbitalia, enamel hypoplasia, periostitis, sinusitis, pleurisy, endocranial changes) and signs of metabolic diseases (osteoporosis/demineralization, vitamin C and D deficiency). Dental and periodontal disease (caries, tooth loss) can give general information on the health status and living conditions of a population, enamel hypoplasias further on weaning practices. As a second line of evidence for breastfeeding and weaning, we submitted seven samples from the ribs of individuals of different ages to Beta Analytic for isotope-ratio mass spectrometry (IRMS) measurement of $\% \mathrm{C}\left(\delta^{13} \mathrm{C}\right)$, $\% \mathrm{~N}\left(\delta^{15} \mathrm{~N}\right)$ and $\mathrm{C}: \mathrm{N}$ ratio.

Degenerative joint changes to the femoral head or the lumbar vertebrae were noted due to their potential influence on the morphology of pelvic features. We recorded ten pelvic features in the bones of the pelvic girdle which may be of interest in relation to pregnancies and childbirth events, in order to understand motherhood and its physical and social consequences for women. These include the shape and stage of the preauricular sulcus, the margo auricularis groove at the sacrum, lesions on the dorsal pubic surface (dorsal pitting), lesions and exostoses on the ventral pubic surface, the shape and exact location of the extended pubic tubercle, ${ }^{51}$ sacral preauricular extensions and notches, corresponding facets to the iliac bones, and, complementary to this, exostoses at the margin of the iliac facies auricularis, which can also be age-related. ${ }^{52}$ We also assessed adjacent skeletal elements, particularly details on the lumbar spine.

49 Following the descriptive protocols outlined by LovelL 1997.

50 Cattaneo, Cappella 2017.

51 The features and their recording systems are described in detail in REBAY-SALISBURY et al. 2018, 93.

52 Pany-Kucera, Spannagl-Steiner, Rebay-Salisbury 2018a. PANY-KuCERA et al. 2019.
For each person, we represent the aggregation of pelvic changes as a single value, the 'Pelvic Pattern Index' (PPI). ${ }^{53}$ The Pelvic Pattern Index can be calculated to compare pelvic patterns within a skeletal series, to other skeletal samples and to the archaeological record to estimate impact levels in terms of load on the pelvis. Elevated values may indicate strain experienced through pregnancies and birthing events, but may also stem from other biomechanical stressors.

\subsection{Tooth Cementum Annulation Analysis}

Tooth cementum annulation analysis was conducted on seven individuals from Schleinbach to confirm and refine the morphological age assessment (9, 30, 31, 56, 60, 1983/ Grube 61 and 1983/Grube 71). Three thin sections of one dental root per individual were prepared at the Centre for Forensic Medicine of the Medical University of Vienna.

Tooth cementum, a connective tissue that surrounds the dental roots, deposits in incremental growth lines visible under the microscope in histological thin sections; each pair of a light and a dark band corresponds to a full seasonal cycle. Counting the number of cementum annulations and adding the number of paired lines to the estimated year of eruption of the analysed tooth ${ }^{54}$ reveals the histological age of the individual..$^{55}$ In addition to the age at death, tooth cementum annulation analysis may also give insights about the season of death ${ }^{56}$ and life events such as pregnancies, skeletal traumas and certain diseases. ${ }^{57}$

In archaeological samples, fungal growth and erosion may affect the preservation of the dental cementum. As an alternative to counting all lines across the whole of the cementum section, we counted the average distance between lines in a well-preserved area and extrapolated the results across the entire section. The number of incremental lines is the total width of the cementum divided by the width between two incremental lines. ${ }^{58}$ For example, a lower left second premolar of the 30-35-year-old male individual from a multiple burial in Pit 60 (sample 5628) is overlaid with fungus so it is difficult to see most of the lines. The total width of the cementum is $116.11 \mu \mathrm{m}$ and the mean distance between two lines $4.43 \mu \mathrm{m}$, resulting in 26.2 extrapolated lines across the cementum, which equals an age of $37.7 \pm 5$ years.

53 We refined the approach used at Unterhautzenthal (REBAY-SALISBURY et al. 2018, 98, Parity Index) to include a mathematical formalization: Pany-Kucera, Spannagl-Steiner, Rebay-Salisbury 2018 b.

54 AlQahtani, Hector, Liversidge 2010.

55 Wittwer-Backofen, Gampe, Vaupel 2004. - Bertrand et al. 2016. - Blondiaux et al. 2016. - Naji et al. 2016.

56 Meckel 2016. - Ralston 2016. - Wedel, Wescott 2016.

57 Kagerer, Grupe 2001. - Künzie, Wittwer-Backofen 2008.

58 GuPTA et al. 2014. 


\subsection{Mitochondrial DNA Analysis}

In order to test the biological relatedness of the individuals buried together in the double burial 30/31 and the multiple burial 60, six samples of teeth were sent for mtDNA analysis to Christina Strobl and Walther Parson from the Institute of Legal Medicine, Medical University of Innsbruck.

The six teeth were analysed according to the protocol published in Parson et al. 2018.59 In brief, the surfaces of the teeth were mechanically cleaned using a dremel tool and chemically cleaned using a $5 \%$ bleach solution. The teeth were carefully drilled with a dental drill at low speed to prevent overheating, the roots were subjected to milling in a Retsch grinding mill MM400 (Retsch GmbH, Haan, Germany). The resulting powder was lysed and DNA was extracted following the protocol described in Odile M. Loreille et al. 2007.60 Estimation of mtDNA copy number was performed using a tetraplex real-time PCR quantitation system. ${ }^{61}$ Specimens that resulted in the highest $\mathrm{mtD}$ NA yields (drill or mill) were directly subjected to sequence library preparation using the IonXpress Fragment Library Kit (TFS) according to the manufacturer's protocol and as described in Mayra Eduardoff et al. 2017.62 The libraries were sequenced on the Ion S5 (TFS) with automated template preparation using the IonChef pipeline (TFS) according to the manufacturer's protocol. Raw data analysis was performed using the IonTorrent Server analysis pipeline. MtDNA sequence variants were manually reported relative to the rCRS revised Cambridge Reference Sequence, ${ }^{63}$ based on phylogenetic alignment considerations. ${ }^{64}$ Polynucleotide stretches were not analysed. Haplogroups were determined based on Phylotree, ${ }^{65}$ using the haplogrouping function in EMPOP. ${ }^{66}$

\subsection{Proteomic Sex Identification}

The identification of sexually dimorphic amelogenin protein fragments in dental tooth enamel by nanoflow liquid chromatography-tandem mass spectrometry (nanoLC-MS/MS $)^{67}$ has emerged as a new, minimally destructive method to assess the sex of children, even if nuclear DNA is

\footnotetext{
59 PARson et al. 2018.

60 Loreille et al. 2007.

61 Xavier et al. 2019.

62 EduARdoff et al. 2017.

63 Andrews et al. 1999.

64 According to Bandelt, Parson 2008. - Parson et al. 2014.

65 Build 17 www.phylotree.org (last access 21.9.2020): van Oven, KAYSER 2009.

66 https://empop.online (last access 21.9.2020): PARson, Dur 2007.

67 STEWARt et al. 2016. - STEwart et al. 2017. - PArker et al. 2019. -

Cappellini et al. 2019.
}

not preserved. We applied this method to four juvenile individuals from Schleinbach and sampled the left deciduous mandibular canine (FDI 73) of the 5-6-year-old child from Feature 1981/Grube 3, ${ }^{68}$ the left mandibular second molar (FDI 75) of the 8-9-year-old individual A from Pit 60, the right mandibular second molar (FDI 85) of the c. 12-yearold individual $\mathrm{B}$ from Pit 60, and the right maxillary second molar(FDI 55) of the 3-4-year-old individual C from Pit 60.

Samples were prepared at the Medical University of Vienna $^{69}$ and analysis took place at the Department of Analytical Chemistry of the University of Vienna. We chose a c. $2.5 \times 2.5 \mathrm{~mm}$ well-accessible area on each tooth surface.

A small fraction of the tooth enamel was abraded using fine grit sandpaper. The tooth was subsequently washed with $4 \%$ (v/v) hydrogen peroxide (8070.1; Carl Roth) and rinsed with MS grade water (83645.320; VWR). The abraded part of the tooth's surface was immersed in $120 \mu \mathrm{L} 5 \%$ (v/v) hydrochloric acid (1.00317.100; Merck) and etched for two minutes. After the first etch solution was discarded, a second etch was performed similarly to the first one, which was further processed. C18 ZipTips (87782; Pierce ${ }^{\circledR}$ C18 Tips, Thermo Scientific) were used for the peptide clean-up procedure. The C18 ZipTip conditioning was performed by pipetting $10 \mu \mathrm{L} 100 \%$ acetonitrile (83639.320; VWR) three times, followed by $10 \mu \mathrm{L} 0.1 \%$ (v/v) formic acid (84865.180; VWR) three times. Each draw was discarded. The etch solution containing enamel peptides was transferred onto the pre-conditioned C18 ZipTip by transferring the solution into a clean tube, totalling 20 pipette strokes. The resin was washed by pipetting $10 \mu \mathrm{L} 0.1 \%$ formic acid six times; each draw was discarded. Elution of peptides was performed by pipetting $10 \mu \mathrm{L}$ of elution buffer ( $60 \% \mathrm{ACN}, 0.1 \% \mathrm{FA}$ ) into a clean tube twice. The sample was dried in a vacuum concentrator and reconstituted in $2 \mu \mathrm{L} 30 \%$ formic acid solution containing four synthetic standard peptides $(10 \mathrm{fM}$ each) for internal quality control, $10 \mu \mathrm{L}$ Eluent A (98 \% MS grade water, $2 \%$ ACN, $0.1 \%$ FA) were added.

Analysis was performed employing a Dionex Ultimate 3000 RSL Cnano system coupled to a Q Exactive orbitrap mass spectrometer equipped with a nanospray ion source. ${ }^{70}$ The measurement protocol for LC and MS conditions was an adapted version of a recently published method. ${ }^{71}$

Data analysis was performed, employing an adapted approach from Nicolas Andre Stewart et al. 2017, focusing

\footnotetext{
68 Rebay-SAlisbury et al. 2020.

69 Following a slightly modified version of the protocol described by STEWART et al. 2017.

70 For more details, see JANKER et al. 2019.

71 STEWART et al. 2017.
} 


\begin{tabular}{|c|c|c|c|c|c|c|c|}
\hline Individual & $\begin{array}{l}\text { Femur 1: } \\
\text { maximum } \\
\text { length }(\mathrm{cm})\end{array}$ & $\begin{array}{l}\text { Body height } \\
\text { females } \\
\text { (RuFf et al. 2012) }\end{array}$ & $\begin{array}{c}\text { Body height } \\
\text { males } \\
\text { (RUFF et al. 2012) }\end{array}$ & $\begin{array}{c}\text { Minimum } \\
\text { body height } \\
\text { (SJøvOLD 1990) }\end{array}$ & $\begin{array}{l}\text { Maximum body } \\
\text { height } \\
\text { (SJøvOLD 1990) }\end{array}$ & $\begin{array}{c}\text { Body height } \\
\text { females } \\
\text { (SJøvOLD 1990) }\end{array}$ & $\begin{array}{l}\text { Body height } \\
\text { males } \\
\text { (SJøvOLD 1990) }\end{array}$ \\
\hline $9 \mathrm{~A}$ & 44.3 & $162.7 \pm 2.92$ & & 161.4 & 170.4 & $165.9 \pm 4.49$ & \\
\hline 11 & 41.8 & $156.0 \pm 2.92$ & & 154.6 & 163.6 & $159.1 \pm 4.49$ & \\
\hline 14 & 39.9 & $150.9 \pm 2.92$ & & 149.5 & 158.5 & $154.0 \pm 4.49$ & \\
\hline 15 & 43.5 & & $161.2 \pm 3.21$ & 159.3 & 168.2 & & $163.7 \pm 4.49$ \\
\hline 29 & 43.5 & $160.6 \pm 2.92$ & & 159.3 & 168.2 & $163.7 \pm 4.49$ & \\
\hline 30 & 44 & & $162.5 \pm 3.21$ & 160.6 & 169.6 & & $165.1 \pm 4.49$ \\
\hline 31 & 47.4 & & $171.8 \pm 3.21$ & 169.8 & 178.8 & & $174.3 \pm 4.49$ \\
\hline 60 & 46.1 & & $168.2 \pm 3.21$ & 166.3 & 175.3 & & $170.8 \pm 4.49$ \\
\hline 90 & 40.9 & $153.6 \pm 2.92$ & & 152.2 & 161.2 & $156.7 \pm 4.49$ & \\
\hline $104 / 1$ & 40.4 & $152.2 \pm 2.92$ & & 150.9 & 159.8 & $155.3 \pm 4.49$ & \\
\hline 108 & 44.5 & & $163.9 \pm 3.21$ & 162.0 & 170.9 & & $166.5 \pm 4.49$ \\
\hline $106 / 1$ & 40.8 & $153.3 \pm 2.92$ & & 151.9 & 160.9 & $156.4 \pm 4.49$ & \\
\hline $109 / 1$ & 43.4 & & $160.9 \pm 3.21$ & 159.0 & 168.0 & & $163.5 \pm 4.49$ \\
\hline Mean & & $155.8 \pm 2.92$ & $164.8 \pm 3.21$ & & & $157.6 \pm 4.49$ & $163.5 \pm 4.49$ \\
\hline
\end{tabular}

Tab. 4. Femoral measurements and estimated body height at Schleinbach.

on unique peptide signals of distinct amelogenin isoforms present in the sample via extraction of precursor signals and calculation of isotopic distribution products by employing the software package Skyline, ${ }^{72}$ as well as sequence annotation through fragmentation experiments.

\section{Results}

\subsection{Age and Sex}

The results of our age and sex assessments led to the revision of previously published biological profile data for the following individuals: the individual from Grave 9A, a 45-55-year-old female according to our assessment, was first published as male, ${ }^{73}$ which was repeated in Rettenbacher $2004^{74}$ despite a contradictory assessment as adult female in Teschler-Nicola 1992. ${ }^{75}$ The individual from Grave 16, a 21-25-year-old woman according to our assessment, was likewise first classified as a $25-35$-year-old male ${ }^{76}$ and later as a juvenile to adult female. ${ }^{77}$ The individual from Grave 18, probably a 30-35-year-old female according to our analysis,

72 MacLean et al. 2010.

73 Weninger 1954b, 32.

74 RetTEnBaCher 2004, 25.

75 Teschler-Nicola 1992, 46-47.

76 WENINGER 1954b, 35.

77 Teschler-Nicola 1992, 46-47. was classified as a 20-25-year-old male ${ }^{78}$ and adult male ${ }^{79}$ in previous works. M. Weninger already doubted the ad hoc interpretation of the double burial 30/31 as that of a man and woman who had to follow the man into the grave in 1954, but this attractive interpretation persisted even in recent publications. ${ }^{80}$ The individuals in question are both male and were $27-30$ and $30-35$ years old at death.

\subsection{Body Stature}

Females in the community of Schleinbach were on average c. $156 \mathrm{~cm}$ tall, males c. $165 \mathrm{~cm}$ (Tab. 4), which compares well to individuals from Unterhautzenthal. ${ }^{81}$ There is no correlation between social status and body height.

The c. 12-year-old child 60B from the multiple burial in Pit 60 has a noticeable discrepancy between the age derived from the dentition (M2 nearly in masticatory plane, but persisting deciduous teeth) and the measurements of the diaphyseal length of the bones (femur $287 \mathrm{~mm}$ ). The body height was reconstructed at 115-119 cm, which corresponds to an age of 8-9 years. For comparison, child 60A, with a dental age of $8-9$, has a femoral length of $292 \mathrm{~mm}$

\footnotetext{
78 WeNINGER 1954b, 35.

79 Teschler-Nicola 1992, 46-47.

80 See Rebay-Salisbury 2018 for a detailed discussion.

$81156 \mathrm{~cm}$ for women, $166 \mathrm{~cm}$ for men: REBAY-SALISBURY et al. 2018, 85 .
} 
and a reconstructed body height of 120-124 cm. Long bone growth retardation may occur because of severe infections in the first three years of life, malnutrition, genetic and hormonal influences as well as diseases. ${ }^{82}$

\subsection{Traumas}

Cranial injuries were found in 7 of $37(18.9 \%)$ individuals from Schleinbach (Tab. 5, Fig. 9). The adult male from Pit 60 is the only one with a healed cranial lesion; no signs of healing were found in either adult male from the double burial 30/31, the adult male from Grave 102, the young female 1927/1 and the children from Pit 1981/Grube 3 and Pit 60 (individual $60 \mathrm{C}$ ). Four of these individuals additionally suffered multiple postcranial fractures. Males were distinctly more frequently affected from neurocranial trauma in this group than females (males $44.4 \%$ compared to females $9.1 \%$ ), and most of the lesions were found unhealed. Moreover, 2 of 16 assessable children showed lethal cranial fractures $(12.5 \%)$, and neurocranial trauma was found with a higher frequency in individuals not buried in graves.

\begin{tabular}{|l|c|c|c|c|}
\hline & $\begin{array}{c}\text { Degree } \\
\text { of } \\
\text { expression }\end{array}$ & $\begin{array}{c}\text { Neuro- } \\
\text { cranium }\end{array}$ & $\begin{array}{c}\text { Postcranium } \\
\text { upper limb }\end{array}$ & $\begin{array}{c}\text { Postcranium } \\
\text { lower limb }\end{array}$ \\
\hline Males & 0 & $5 / 14$ & $4 / 14$ & $3 / 14$ \\
\hline & 1 & $5 / 9$ & $8 / 10$ & $8 / 11$ \\
\hline & 2 & $1 / 9$ & $1 / 10$ & $1 / 11$ \\
\hline & 3 & $3 / 9$ & $1 / 10$ & $1 / 11$ \\
\hline Females & 0 & $6 / 17$ & $6 / 17$ & $4 / 17$ \\
\hline & 1 & $10 / 11$ & $8 / 13$ & $11 / 13$ \\
\hline & 2 & 0 & $2 / 13$ & $1 / 13$ \\
\hline & 3 & $1 / 11$ & $1 / 13$ & $1 / 13$ \\
\hline Undet. & 0 & $3 / 19$ & $6 / 18$ & $2 / 14$ \\
\hline & 1 & $14 / 16$ & $12 / 12$ & $11 / 12$ \\
\hline & 2 & $1 / 16$ & 0 & $1 / 12$ \\
\hline & 3 & $1 / 16$ & 0 & 0 \\
\hline
\end{tabular}

Tab. 5. Frequencies of traumatic lesions at Schleinbach. - Degrees of expression: 0 = not assessable, $1=$ normal, $2=$ one lesion, $3=$ two or more lesions present.

Healed postcranial upper limb fractures were documented in 5 of $19(26.3 \%)$ adults. The females from Grave 9 and Grave 107 show healed possible parry fractures of the

82 Lovejoy, Russell, Harrison 1990.

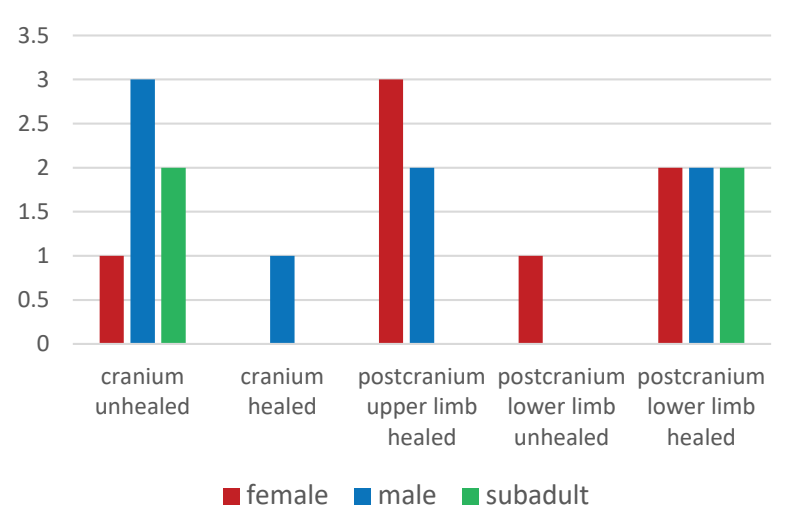

Fig. 9. Healed and unhealed, cranial and postcranial fractures in males, females and children from Schleinbach $(n=63)$.

ulnae, and the female from Grave 56 had several healed sacrum fractures and both distal forearms were fractured. Bilateral, largely healed fractures of the spina scapulae were found in male 1927/2. Postcranial lower limb lesions, healed and unhealed, were found in 5 of 21 adults $(20 \% ; 30,31$, $56,104 / 1$ and 108 , only haematoma), the 8-9-year-old male child from 60A, and the 7-9-year-old child from Grave 111.

Trauma patterns in single individuals demonstrate the extent of violence prevalent in the Early Bronze Age. The well-healed fracture with callus formation found in the distal part of the left ulna of the 45-55-year-old female from Grave 9 most likely represents a parry fracture.

The 40-55-year-old female from Pit 56 reveals wellhealed fractures in the distal part of both radii, and superficial bony changes in the right ulna, but no fracture was visible in the radiograph (damage to the distal left). The sacrum of this female, consisting of six vertebrae, exhibited multiple fractures (Fig. 10) including a well-healed, incision-shaped fracture of the right ala ossis sacri, with a fracture line from the middle of the ala to the auricular facet. This fracture also affects the upper quarter of the sacral auricular facet, presenting as a sharp bend in the upper part of the surface, as well as the auricular surface of the ilium. The joint surface in the upper part is completely remodelled with a lateral rim formation. The right ala is narrower than the left one (right: $26.9 \mathrm{~mm}$, left: $33.4 \mathrm{~mm}$ from the lateral margin of the basis ossis sacri to the lateral margin of the ala). Another wellhealed fracture leads horizontally through the right lateral part of the third sacral segment, with a small vertical fracture line from the second to the third anterior sacral foramen. The third fracture, probably continuing from the second one, presents as a horizontal area of about $10 \mathrm{~mm}$ in width, c. $5 \mathrm{~mm}$ below the second transverse line. The distinct kyphosis in this area points to a burst fracture. In this area, new 


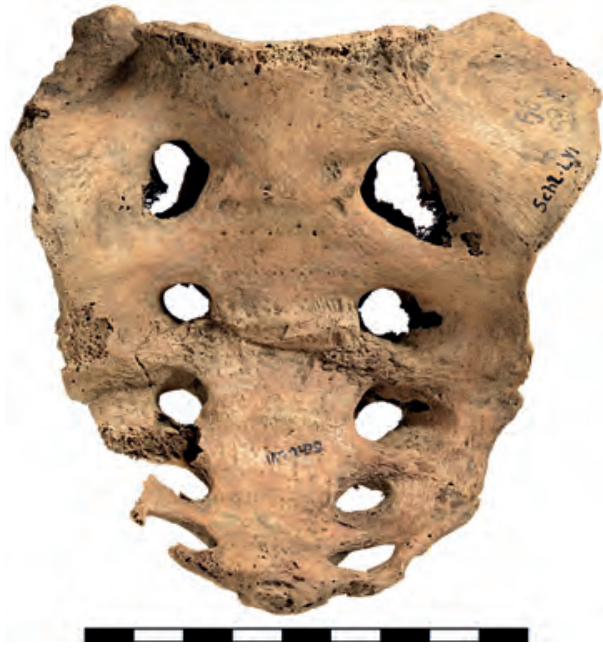

Fig. 10. Fractures in the sacrum of the 40-55-year-old female from Pit 56 (Photo: W. Reichmann, () NHM Vienna).

bone apposition represents inflammatory changes from the healing process. The fourth healed fracture continues in the left lateral part of the sacrum to the lateral margin. Moreover, a crack was observed in the middle of the crista sacralis mediana, and she suffered from a healed fracture in the left fourth metacarpal, and from partial fractures of some ribs.

The third lumbar vertebra was probably affected by a compression fracture, as the right upper plate in particular is flattened on the ventral side. The asymmetry in the sacroiliac joint may be a result of the fracture pattern in this female individual. Most likely, the exostoses on the tubera of the os ischium were caused by altered muscle strains in this region. This rare pelvic trauma pattern is most likely the result of a fall from a height; ${ }^{83}$ the bilateral healed fractures of the lower arm bones support this assessment. Whereas the majority of the sacral fractures are well healed, woven bone at the transverse fracture site at the level of S2-S3 indicates active healing. Either this fracture occurred later than the others did, or the fracture never healed, leading to a chronic inflammation.

The two males from the double burial 30/31 (Fig. 7), aged 27-30 and 30-35 years, were found with unhealed peri-mortem neurocranial injuries in the same location in the left temporal region. The fractures are very similar, large burst fractures with radial fracture lines $(\varnothing$ c. $60 \mathrm{~mm}$, Fig. 11). The lesion in the cranium of individual 30 is round to oval, with sharp margins and chipping to the internal lamina. It is accompanied by an unhealed fracture in the left anterior part of the mandible, extending from the mentum

83 Bydon et al. 2014. - Rodrigues-Pinto et al. 2017.

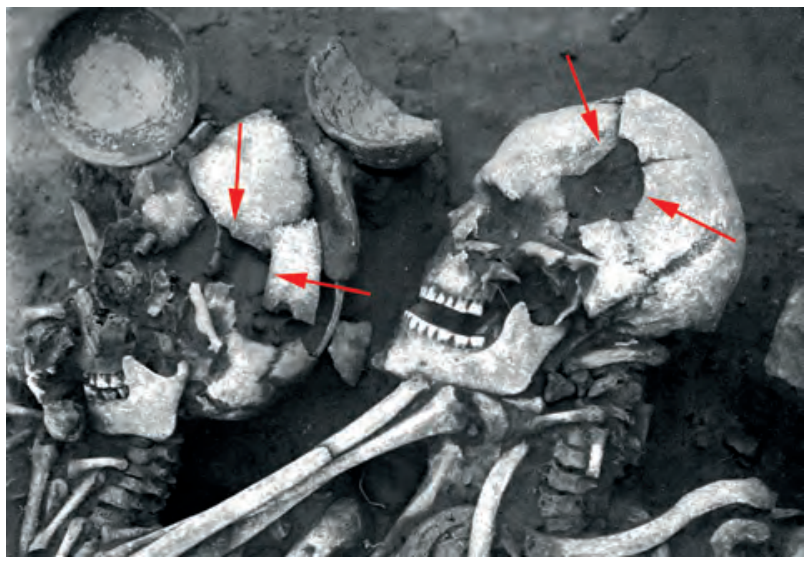

Fig. 11. Individuals 30 and 31 with almost identical peri-mortem injuries to the left parietal bones (Photo: K. Kriegler, ( $\odot$ Landessammlungen Niederösterreich, Bereich Ur- und Frühgeschichte, No. 17884).

to the premolars, and chipping of the tooth crowns. He furthermore shows a lumbosacral transitional vertebra on the left side ${ }^{84}$ a 'false joint' between the enlarged lateral part of L5 and the ala ossis sacri. An anterior pelvic ring fracture is probably due to lateral compression caused by side-impact accidents and falls. ${ }^{85}$ The fracture of the left superior pubic ramus shows clear signs of healing, whereas the inferior pubic ramus is eroded and therefore difficult to evaluate.

Individual 31's cranial lesion in the left parietal bone near the coronal suture is also accompanied by characteristic fracture lines. Chipping is visible in the internal layer of the cranium, and the temporal bone and zygomatic process show related sharp-edged fracture lines. A healed compression fracture to the left side of the fifth lumbar vertebra and signs of an inferior subluxation of the shoulder in the left glenoid cavity were found in the same individual. The lower border of the left glenoid cavity of the scapula developed a new, smooth joint surface $(20 \times 15 \mathrm{~mm})$. Interestingly, this traumatic event did not result in alterations in the humeral head itself.

Two of the individuals from the multiple burial of a male with three children in Pit 60 show cranial lesions. A circular, well-healed depression fracture was found in the left lateral part of the frontal bone of the 30-35-year-old male 60 (Ø $15 \mathrm{~mm}$, c. $10 \mathrm{~mm}$ deep, Fig. 12).

84 Bertolotti's syndrome: Jancuska, Spivak, Bendo 2015.

85 Type 1, Young and Burgess classification: Khurana et al. 2014. 


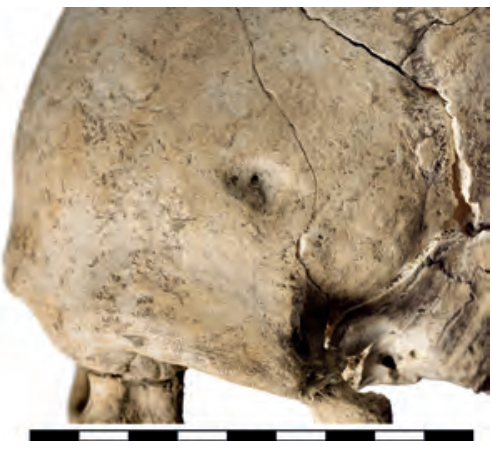

Fig. 12. Cranial lesion on the left side of the frontal bone of the 30-35-year-old male 60 (Photo: W. Reichmann, () NHM Vienna).

The 3-4-year-old child 60C exhibits a star-shaped, peri-mortem burst fracture of the left parietal bone, with five radial fracture lines emerging from the points. The internal lamina is chipped $(45 \times 25 \mathrm{~mm}$, Fig. 13$)$.

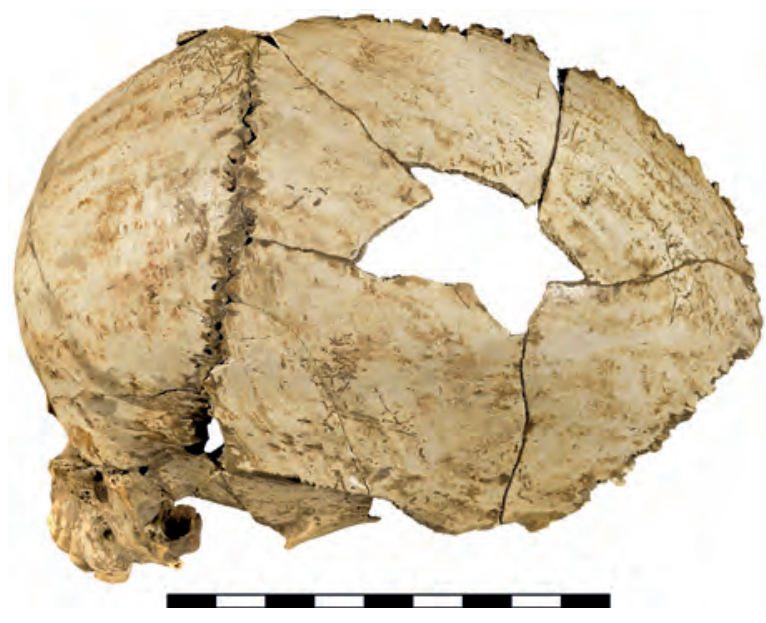

Fig. 13. The 3-4-year-old child $60 \mathrm{C}$ with burst fracture in the left parietal (Photo: W. Reichmann, (C) NHM Vienna).

The remains of the adult individual 1983/Grube 61, found in a pit, consist of the viscerocranium without mandible and a small part of the frontal bone. The nasal bone and the superior orbital margin show a peri- or post-mortem horizontal fracture line, the maxillary tooth crowns are completely chipped off and only the roots of the teeth remained in the alveolar bone. The frontal bone reveals a peri- or post-mortem horizontal linear fracture including chipping of the inner table, with continuation into the temporal bone. Although it cannot be ascertained whether the injuries occurred pre- or post-mortally, the skull appears abraded and eroded. This may point to the curation and

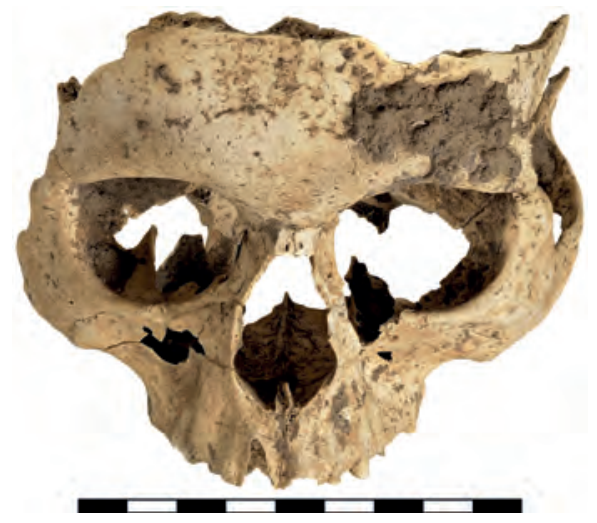

Fig. 14. Cranial remains of the adult individual 1983/Grube 61 (Photo: W. Reichmann, () NHM Vienna).

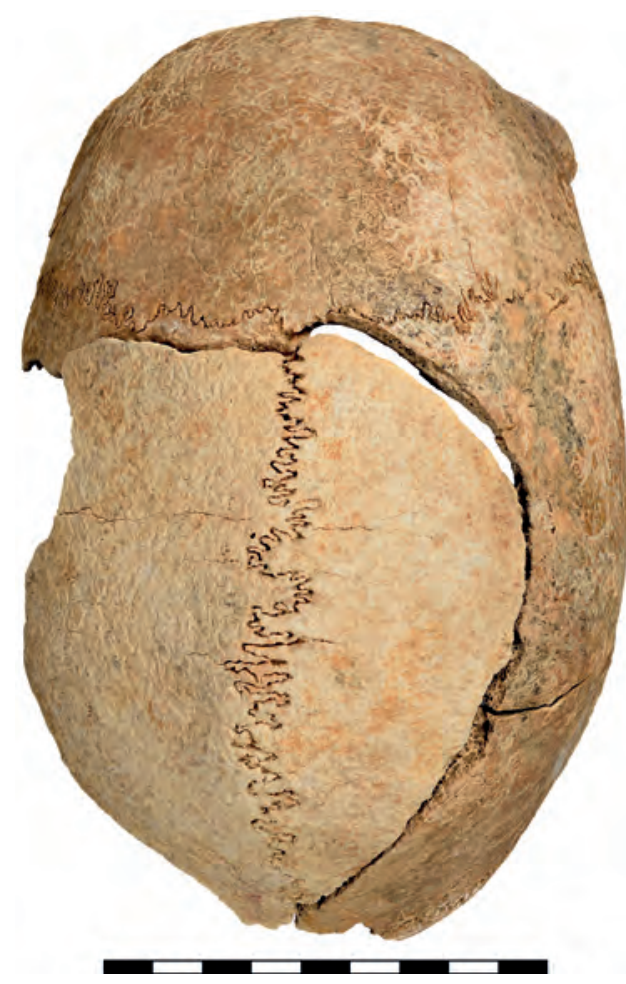

Fig. 15. Peri-mortem sharp force polytrauma to the cranium of the 25-30-year-old male from Grave 102 (Photo: W. Reichmann, () NHM Vienna).

circulation of this person's facial remains for a longer pe$\operatorname{riod}$ (Fig. 14).

A peri-mortem sharp force polytrauma of extraordinary extent was found in the cranium of the 25-30-year-old male from Grave 102 (Fig. 15). A horizontal crack extends in an arch from the bregma (mid-point of the coronal suture) to 
the lambda (mid-point of the lambdoidal suture). This fatal sharp force injury might have been caused by a blow to the left side of the cranium. A bevelled edge was noticed in the left parietal bone near the coronal suture, perhaps from a second sharp cut. A triangular piece of the left orbital margin of the frontal bone was broken off. Several other cranial fragments of the parietal and occipital bones show signs of fracture.

Severe osteophyte growth, especially on the left side of the base plate of the fifth lumbar vertebra of the 30-35-yearold female from Grave 104/1, started to bridge to the first segment of the sacrum. The origin of the lesion is unclear. It may be traumatically induced and is accompanied by possible inflammatory signs. The left calcaneus reveals a small, cone-like exostosis at the fronto-lateral margin of the bone, which may also stem from a trauma.

Healed postcranial traumatic lesions were found in the 40-60-year-old female from Grave 107, one on the distal shaft of the left ulna, most likely a parry fracture, and one on the mid-shaft of the left clavicle, which healed in malposition at a slight angle.

The superior part of the left femur shaft of the 7-9-yearold child buried in Grave 111 appears thickened and slightly bent in the antero-posterior direction. This change in the normal morphology of the femur points to a greenstick fracture in the early life of this child. The 8-9-year-old boy $60 \mathrm{~A}$ exhibits a healed avulsion fracture of the lateral tubercle of the right talus.

The 30-40-year-old male from Grave 115 suffered from a severe fracture at the distal end of the left radius, probably involving the carpal bones. The epiphysis of the radius is thickened and shows signs of osteoarthritis. During the fracture event, the os lunatum was shattered and later merged with the joint surface at the facies articularis carpea, the joint surface facing the carpal bones. The preserved part of the circumferentia articularis at the caput ulnae corresponding to the radius shows only slight remodelling. Since the lesion healed and a pseudo joint developed, the hand appears to have been used after the incident, despite the pain (Fig. 16).

Two peri-mortem, slightly overlapping round to oval sharp force traumas were found in the right parietal and frontal bones of the 18-21-year-old female 1927/1 (Fig. 17). The smaller injury (c. $18 \times 27 \mathrm{~mm}$ ) affects the right parietal and frontal bone equally, and partly overlaps with the larger one (c. $25 \times 33 \mathrm{~mm}$ ) located around the bregma; it affects a small portion of the frontal and right parietal bone as well as the left parietal bone, which is only partly preserved. An unhealed, peri-mortem sharp cut in the left tibia $(12 \mathrm{~mm}$ length) was found in the same individual.
A rare bilateral scapularfracture affected the 40-50-yearold male 1927/2 (Fig. 18). The right scapula exhibits a wellhealed fracture with callus formation in the medial part of the spina scapulae. The left scapula shows a healing fracture with porotic new bone formation in the medio-lateral part of the spina scapulae; perhaps a repeated injury. These rare fractures result from direct trauma, and lesions of the scapular body and vertical scapular spine fractures were ascribed to beatings. ${ }^{86}$ Only the spinae of the scapulae are affected by a transversal healed fracture in this case, which may be a result of repeatedly carrying heavy loads on the back.

The remains of a 5-6-year-old child with multiple cranial fractures were found in Pit 1981/Grube 3 (Fig. 19). The cranium shows four peri-mortem blunt force traumas: an oval-shaped impression fracture with partial penetration of the inner and outer table is located on the left side of the frontal and parietal bone in the area of the coronal suture $(60$ $\times 35 \mathrm{~mm}$ ). The lesion represents an incomplete impression fracture; the dorsal part is still attached. This lesion could represent the location of the first blow. Two smaller, round to oval-shaped comminuted lesions with linear and radial fracture lines were detected in the right parietal bone, one in the area of the parietal tubercle and the other next to the sagittal suture in the area of S2 (Ø $25 \mathrm{~mm}$ each). The fourth lesion is a large, circular impression fracture with complete penetration of the skull in the right parietal and occipital bones in the area of lambdoid suture ( $\varnothing 45 \mathrm{~mm})$.

\subsection{Health Aspects}

\section{Non-specific indicators of stress and infections}

The causes of unspecific indicators of stress and infection are multifactorial, but deprivation and stress are frequently involved. ${ }^{87}$ At Schleinbach, 3 of 15 (20\%) assessable adults were affected by cribra orbitalia (Pit 61: 20-40 years, undetermined sex, bilateral clustered porosities, Stage 3; 15 : 21-25-year-old male with a cluster of fine foramina in the left orbit, Stage 2; 56: 40-55-year-old female, small area with porosity on the right orbital roof). 3 out of 11 children $(27.3 \%)$ with preserved orbital roofs showed severe orbital cribra (13: 14-year-old with right orbit Stage 3, left orbit Stage 2; 60C: 3-4-year-old with fine foramina covering the roof of both orbita, Stage 2; 91:3-5-year-old with fine porotic cribra orbitalia in the left orbital roof, Stage 2).

Porotic hyperostosis was found in the form of pitting in the parietal and occipital bones of the lamina externa of the cranium in 4 of 15 assessable adults $(26.7 \%$, features $32 / 2,56,63,101 / 2)$. Only 1 of 17 children (5.9\%), the

86 Resnick 1995, 2719. - Blondiaux et al. 2012. - Mays 2015. 87 See Rebay-SAlisbury et al. 2018 for a summarized overview. 


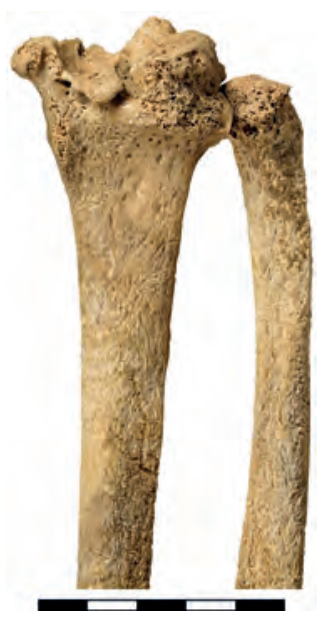

Fig. 16. Fracture and remodelling of the left wrist of the 30-40-yearold male from Grave 115 (Photo: W. Reichmann, () NHM Vienna).

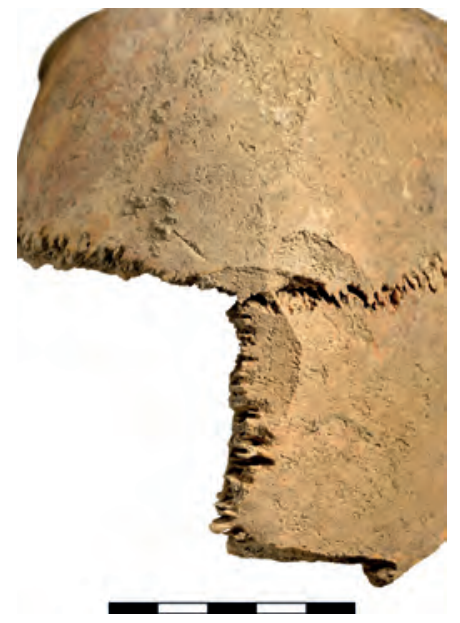

Fig. 17. Sharp force traumas to the right parietal and frontal bones of the 18-21-year-old female 1927/1 (Photo: W. Reichmann, (C) NHM Vienna).

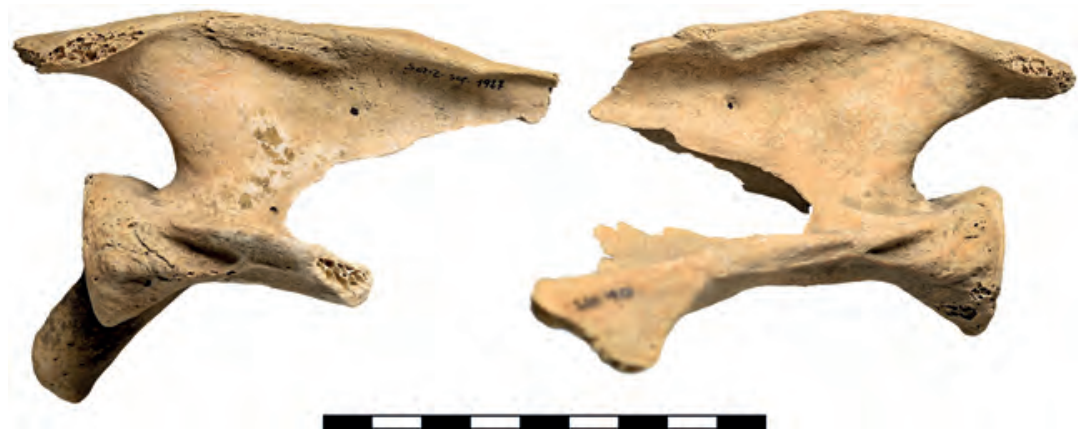

Fig. 18. Bilateral scapular fracture in the 40-50-year-old male 1927/2

(Photo: W. Reichmann, () NHM Vienna).
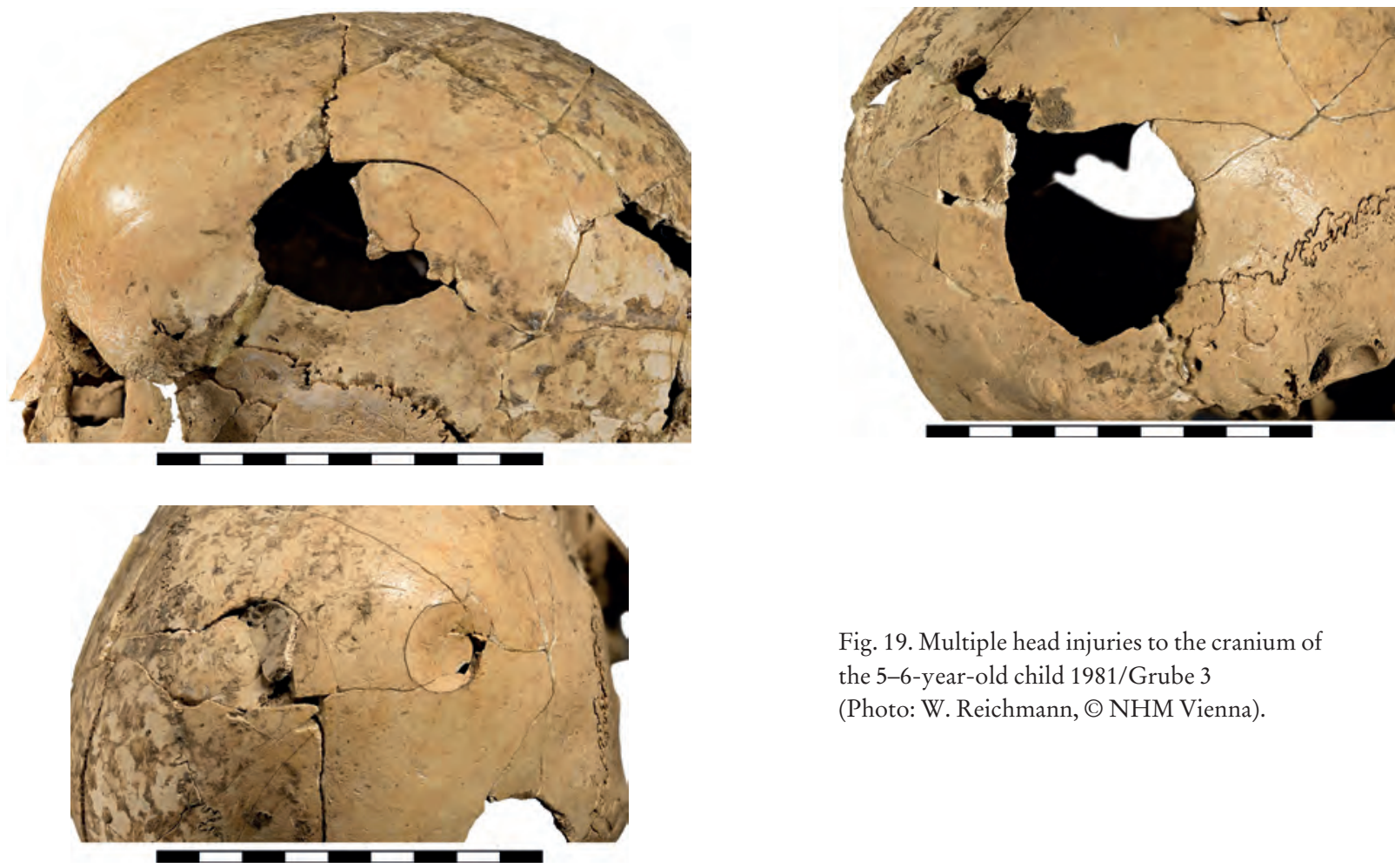

Fig. 19. Multiple head injuries to the cranium of the 5-6-year-old child 1981/Grube 3 (Photo: W. Reichmann, () NHM Vienna). 


\begin{tabular}{|c|c|c|c|c|c|c|c|c|c|}
\hline Beta no. & Individual & Sex & Age & $\begin{array}{c}\text { Sampled } \\
\text { material }\end{array}$ & $\begin{array}{c}\text { IRMS } \\
\delta^{13} \mathbf{C}\end{array}$ & $\begin{array}{c}\text { IRMS } \\
\delta^{15} \mathbf{N}\end{array}$ & $\begin{array}{c}\text { C:N } \\
\text { ratio }\end{array}$ & $\begin{array}{c}\text { Wt } \% \mathbf{C} \\
\text { (concentration of C) }\end{array}$ & $\begin{array}{c}\text { Wt } \% \mathbf{N} \\
\text { (concentration of N) }\end{array}$ \\
\hline 490671 & $9 \mathrm{~A}$ & female & $45-55$ years & rib & -19.1 & 11.34 & 3.2 & 41.97 & 15.08 \\
\hline 490672 & 12 & - & $5-6$ years & rib & -19.3 & 11.37 & 3.3 & 40.12 & 14.29 \\
\hline 490673 & 22 & - & $3.5-4.5$ years & rib & -18.7 & 11.82 & 3.3 & 41.61 & 14.88 \\
\hline 494944 & 30 & male & $27-30$ years & rib & -19.2 & 11.39 & 3.3 & 39.98 & 14.05 \\
\hline 490674 & $60 \mathrm{C}$ & - & $3-4$ years & rib & -19.6 & 12.92 & 3.3 & 41.21 & 14.65 \\
\hline 490662 & 105 & & $3-4$ years & rib & -19.49 & 11.56 & 3.2 & 42.93 & 15.43 \\
\hline 494945 & $1927 / 1$ & female & $18-21$ years & rib & -19.1 & 11.89 & 3.3 & 33.74 & 11.95 \\
\hline All & Average & & & & -19.22 & 11.76 & 3.3 & & \\
\hline
\end{tabular}

Tab. 6. Carbon and nitrogen isotope values from Schleinbach individuals.

8-9-year-old 60A from the multiple burial in Pit 60, revealed porotic hyperostosis in the form of fine porosities in the parietal bones.

Four adolescent individuals (of 14 subadults, $28.6 \%$ ) and none of the 13 assessable adults revealed linear enamel hypoplasias in their incisors and canines. In all four individuals, the hypoplasias correspond to a similar formation age: between 2.5 and 3.5 years in individual 13, between 2.5 and 3.4 years in individual 14, between 2.9 and 3.5 years in individual 17, and between 2.5 and 3.4 years in individual 1983/Grube 71. Linear enamel hypoplasias indicate physiological stress in early childhood, caused by disease or nutritional stress, which is often experienced during weaning. The findings may suggest that children were weaned after the second year of life at Schleinbach.

The results from the mass spectrometry isotope analyses of weaning practices are very similar to the ones obtained from Unterhautzenthal, ${ }^{88}$ with average values of -19.22 for $\delta^{13} \mathrm{C}$ and 11.76 for $\delta^{15} \mathrm{~N}$ suggesting a terrestrial diet based on C3 resources. The 3-4-year-old child 60C from the multiple burial in Pit 60 has elevated $\delta^{15} \mathrm{~N}$ values, which perhaps points to a longer period of breastfeeding, but may be rooted in other causes such as illness and starvation. ${ }^{89}$ The similarly aged individual 105 shows no such nursing signal (Tab. 6).

3 out of 14 adult individuals $(21.4 \%)$, all of female sex, have signs of sinusitis in the maxillary sinuses. The 45-55-year-old female from Grave 11 shows remodelled new bone formation in the right maxillary sinus, caused by acute or chronic respiratory infections. The 40-55-year-old female from Pit 56 reveals spiculae and netlike new bone deposits in the right maxillary sinus, pointing to a healed

88 Rebay-Salisbury et al. 2018, 106-107.

89 Reynard, Tuross 2015. - Beaumont et al. 2018. sinusitis. The changes are perhaps related to the periapical abscess in the upper first molar. The 30-45-year-old female 89A was affected by dentogenous sinusitis, with remodelled inflammatory reactions in the right maxillary sinus possibly caused by an apical lesion of the first molar.

Signs of pleurisy were found in 3 of 17 adults (17.6\%) and 5 of 16 subadults $(31.3 \%)$. The adults were all late adult males: acute and healed new bone formation at the upper dorsal rib ends was found from the first rib onwards in 108. The spine of this individual further showed multifocal lytic lesions of the cervical vertebrae 2, 3, 5-7 (4 is missing) and the thoracic vertebrae $1-6$. These changes may be attributed to brucellosis, mycosis or cancer. Partially remodelled new bone formation on the pleural side of some left dorsal ribs was observed in 109/1. The third affected individual, 115, shows bilaterally remodelled periosteal new bone formation in four dorsal rib fragments. Changes on the pleural side of some ribs were found in five subadults, often in the dorsal part $(13,17,105,106 / 1,111)$. The observed fine porous new bone apposition indicates active pleurisy; only the young female 106/1 shows partial healing of the lesions (Fig. 20).

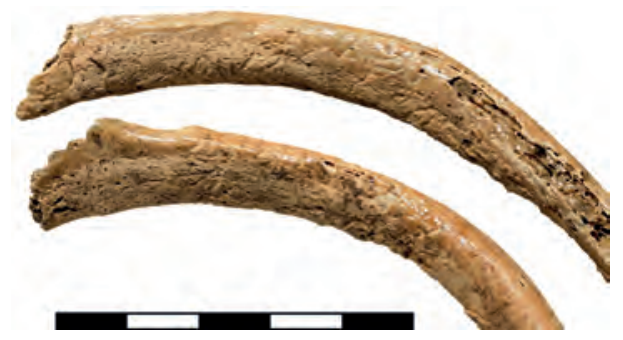

Fig. 20. Pleurisy visible in the dorsal ribs of the 16-20-year-old female from Grave 106/1 (Photo: W. Reichmann, (C NHM Vienna). 


\begin{tabular}{|l|c|c|c|c|c|c|}
\hline & $\begin{array}{c}\text { Degree of } \\
\text { expression }\end{array}$ & Porotic hyperostosis & $\begin{array}{c}\text { Cribra } \\
\text { orbitalia }\end{array}$ & $\begin{array}{c}\text { Periosteal } \\
\text { reactions }\end{array}$ & $\begin{array}{c}\text { Neurocranial } \\
\text { trauma }\end{array}$ & $\begin{array}{c}\text { Intravital } \\
\text { tooth loss }\end{array}$ \\
\hline Graves & 0 & $14 / 34$ & $20 / 30$ & $5 / 34$ & $11 / 32$ & $12 / 33$ \\
\hline & 1 & $19 / 20$ & $8 / 10$ & $22 / 29$ & $18 / 21$ & $18 / 21$ \\
\hline & 2 & $1 / 20$ & $1 / 10$ & $4 / 29$ & $1 / 21$ & $2 / 21$ \\
\hline Settlement features & 3 & 0 & $1 / 10$ & $3 / 29$ & $2 / 21$ & $1 / 21$ \\
\hline & 1 & $7 / 18$ & $3 / 16$ & $9 / 17$ & $3 / 16$ & $5 / 16$ \\
\hline & 2 & $7 / 11$ & $9 / 13$ & $5 / 8$ & $10 / 13$ & $8 / 11$ \\
\hline & 3 & $4 / 11$ & $3 / 13$ & $3 / 8$ & $2 / 13$ & 0 \\
\hline
\end{tabular}

Tab. 7. Differences in frequencies of non-specific signs of stress, neurocranial trauma and intravital tooth loss between individuals buried in graves and settlement features. - Degrees of expression: $0=$ not assessable, $1=$ no pathological change, $2=$ slight pathological change, $3=$ severe pathological change; for neurocranial trauma and intravital tooth loss $3=$ two or more lesions.

Traces of perisinusitis, indicated by secondary new bone formations at the venous blood vessels inside the cranium have been noticed in two individuals, 1 of 15 adults $(6.7 \%$, 18: 30-35-year-old female) and 1 of 13 children $(7.7 \%, 105$ : 3-4-year-old). The female individual showed remodelled changes at the confluens sinuum. The netlike new bone formations in the confluens sinuum and the transverse sinuses of the 3-5-year-old child 105 point to a healing process.

Periostitis, an inflammation of the periosteum, is mainly caused by bacterial infections, but vitamin $\mathrm{C}$ deficiency, local trauma or autoimmune diseases are possible causes, too. At Schleinbach, periostitis was found in 6 of 20 adults $(30 \%, 32 / 2,56,59,60,108,115)$ and 4 of 18 children $(22.2 \%$, $13,14,105,106 / 1)$. New bone formations indicative of active periostitis were found in the proximo-dorsal shaft of the right ulna of the 13-15-year-old from Grave 13, perhaps caused by a local trauma. The 3-4-year-old child 105 shows widespread new bone formation in the shaft of the left femur and the left tibia, which may have been part of a systemic disease such as scurvy. The severe porosity and thickening of the femora and tibiae in the late adult male 115 may be associated with other diseases such as osteomyelitis or osteitis related to the severe wrist fracture. A secondary infection might have spread via the bloodstream. In general, males and females were equally affected by periosteal reactions in this group.

Striations in the bones as possible signs of healed periostitis were detected in the 15-18-year-old individual from Grave 14 (femora and tibiae), the 35-45-year-old female from Pit 32 (right femur shaft), the 40-55-year-old female from Pit 56 (femora, tibiae, signs of remodelled haematoma in the left femur), the 35-45-year-old male from Grave 59, the 30-35-year-old male from multiple burial 60 (femora and tibiae) and the 16-20-year-old female 106/1 (medial shaft of both tibiae). The 40-50-year-old male 1927/2 shows striations in the femora and the right tibia in addition to the acute pathological condition of the left tibia. The reactive new bone formation in the left fibula could indicate an additional soft tissue injury.

Group differences between the 'grave' and the 'others' group were revealed in crosstabs results. An approximate significance for the presence of porotic hyperostosis in the others group as a non-specific sign of stress was found in Kendall's tau-c test for the left side $(\mathrm{p}=.046)$ and close to significant results for the right side $(\mathrm{p}=.051)$. The others group also surpassed the grave-buried individuals in the other non-specific signs of stress, however, not with significant results. Moreover, neurocranial trauma and intravital tooth loss were found with a higher frequency in individuals buried outside formal graves (Tab. 7, Fig. 21).

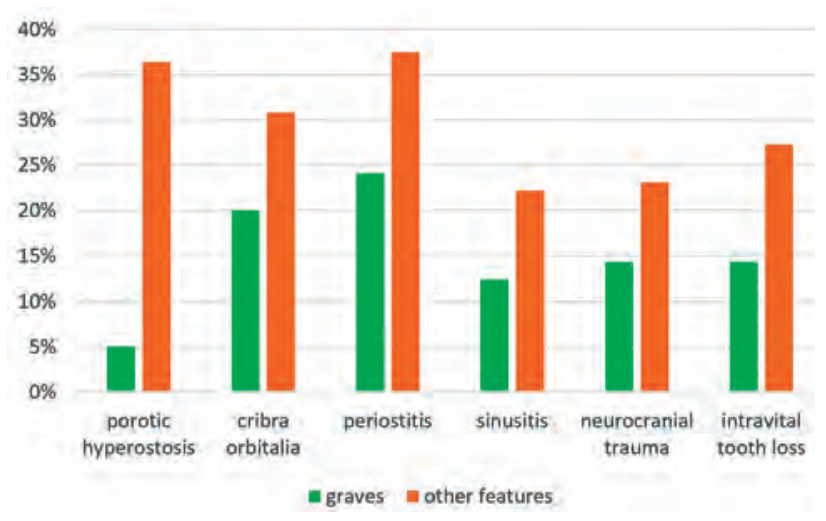

Fig. 21. Percentage of individuals buried in graves and other features affected by non-specific stress signs, neurocranial trauma and intravital tooth loss. 


\section{Metabolic diseases}

Signs of metabolic diseases were found only rarely at Schleinbach. One of the affected individuals is the 15-18-year-old probably female adolescent from Grave 14 . She shows very well remodelled striations on the surface of the femora and tibiae; together with bilateral indentations and flattening in the distal medial part of the femora as well as distinctly bowed tibial shafts, these indicate the disease pattern of rickets. Pronounced attachments of the soleus and the tibialis anterior muscle may add to the picture of altered muscular requirements (Fig. 22).

The 3-4-year-old child from Grave 105 and the 16-20-year-old female from Grave 106/1 were possibly affected by scurvy. The child 105 reveals severe periostitis through extensive new bone apposition in the lateral shaft of the left femur and the medial part of the left tibia. The reactive new bone apposition in the dorso-distal part of both femora (facies poplitea) and the striations in the medial shaft of both tibiae of 106/1 also match the disease pattern of scurvy. The signs of pleurisy in these subadults add to the diagnosis.

The remodelled intensified pitting and new bone formation to the facial bones of the 5-6-year-old child 1981/ Grube 3 affected the maxilla, zygomatic bone, squamous part of the temporal bone and the auditory meatus, possibly indicating (healed?) scurvy. In addition to the metabolic diseases, porotic thickening of the external auditory meatus and osteomyelitic changes in the maxillary bones of this individual might indicate an uncontrolled infection of the middle ear.

In contrast to Unterhautzenthal, there were no noticeable signs of osteoporosis/osteopenia in any of the individuals buried at Schleinbach, except for the female in Pit 56.

\section{Dental and periodontal disease}

Caries, tooth loss and other conspicuous changes in dentition were recorded. Of 21 assessable adult individuals, $2 \mathrm{fe-}$ males and 1 male were affected by carious lesions (14.3\%), $104 / 1$ with a single lesion, and 11 and $89 \mathrm{~B}$ with more than one. Interestingly, none of the 15 subadults showed signs of caries. Intravital tooth loss in the adults was present in 6 of $14(42.9 \%)$ assessable individuals: $11,29,56,89 \mathrm{~A}, 89 \mathrm{~B}$ and 107. Except for 89B, all of the individuals affected by intravital tooth loss are female, three of them (all of them over the age of 30 years) suffered from multiple tooth loss, and intravital tooth loss was found more frequently in individuals buried outside formal graves (Tab. 7). Calculus or its traces were found in the adult individuals 11, 31 and 56 as well as in the children 10 and 60A. A severe alveolar atrophy in child $60 \mathrm{~A}$ was probably caused by the formation of the calculus at a young age.

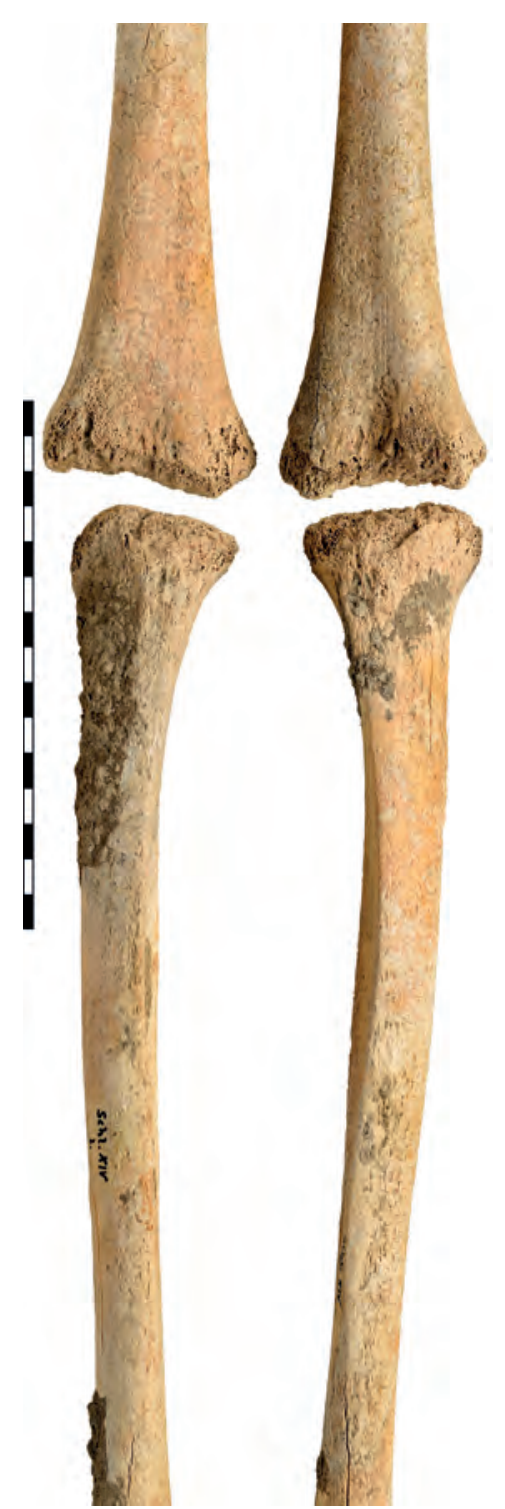

Fig. 22. Femora and tibiae indicating rickets in the 15-18-year-old probably female adolescent from Grave 14 (Photo: W. Reichmann, (c) NHM Vienna).

The 45-55-year-old female from Grave 11 has noticeable changes in her dentition. The three carious lesions in the upper right second molar, the lower left second molar and premolar are all located at the necks of the teeth. Thick dental calculus deposits formed especially in the lower jaw the outer surfaces of the second premolar and the first molar are completely covered. She was further affected by tooth loss and parodontosis as well as an asymmetrical abrasion of the teeth in the upper jaw.

Several periapical abscesses, tooth loss and very strong wear down to the dentine, especially in the maxillary teeth, were found in the dentition of the 40-55-year-old female from Pit 56. Most of the changes, including pronounced 

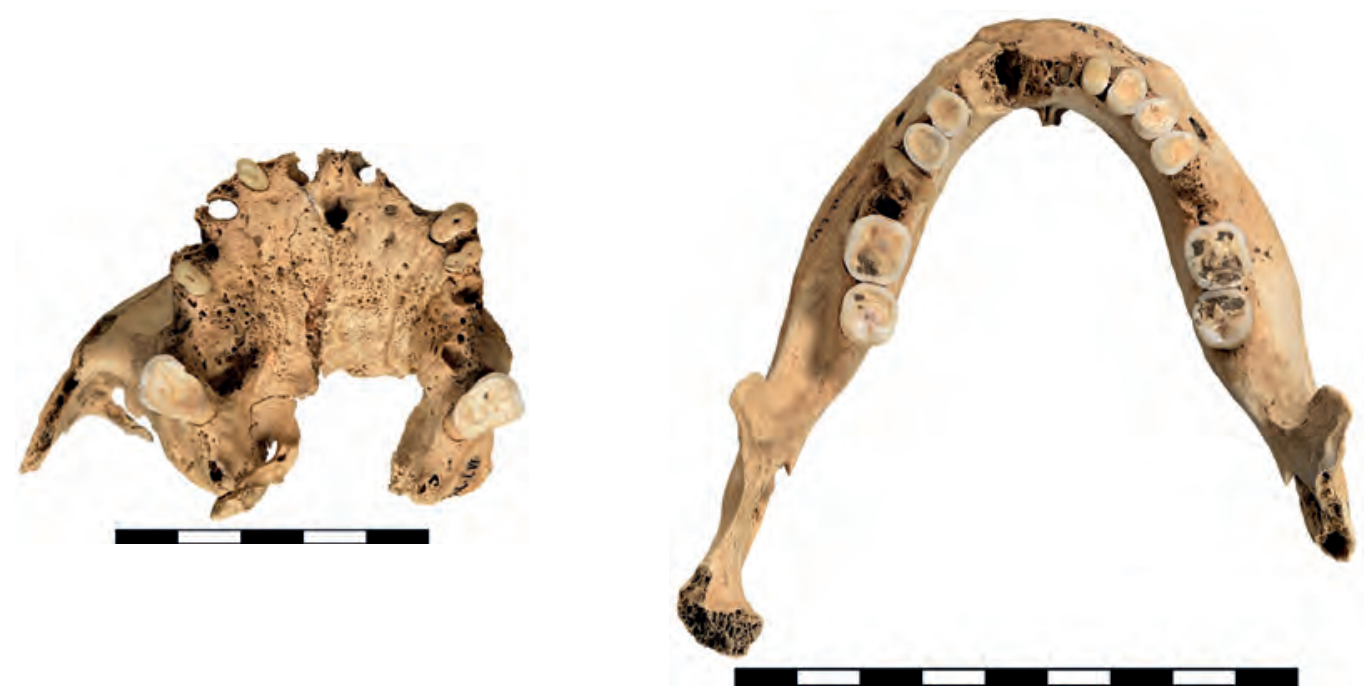

Fig. 23. Dental status of maxilla and mandible of the 40-55-year-old female from Pit 56 (Photo: W. Reichmann, (C NHM Vienna).

stomatitis with spiculae and small ridges on the palate probably stand in a causal relationship with the severe wear of the teeth. The new bone deposits in the right maxillary sinus are probably connected to a periapical abscess at the upper first molar (Fig. 23).

The 30-35-year-old male from the multiple burial in Pit 60 reveals a strong, uniform dental abrasion, especially in the upper jaw. He further suffered from apical abscesses in both upper first molars. The advanced alveolar atrophy may have been caused by extensive calculus formation. The oblique wear on the lingual side of the upper left maxillary premolars and molars as well as the dental chipping, especially in the frontal teeth, point to use of the teeth as a tool (Fig. 24).

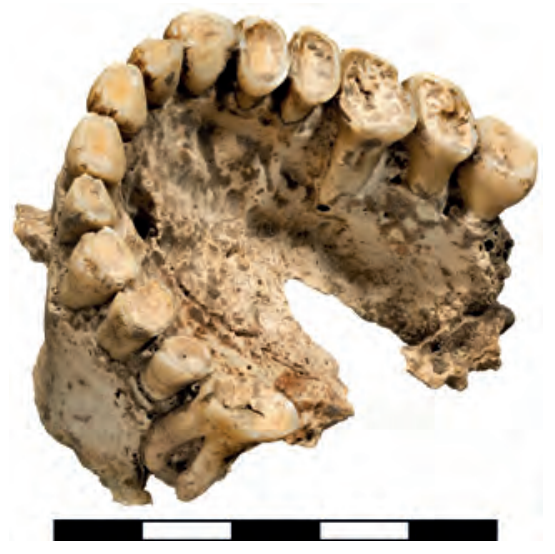

Fig. 24. Tooth wear to the maxilla in the 30-35-year-old male from the multiple burial in Pit 60 (Photo: W. Reichmann, ( NHM Vienna).
The 30-45-year-old female from Pit 89 shows similar changes in her dentition to the female from Pit 56: severe, uniform dental wear in the upper jaw. Furthermore, apical lesions were found at the roots of the upper right and left first molars; signs of severe stomatitis with ridge-like exostoses were found in the palatine. The alveoli of both upper third molars are in the same stage of healing after recent tooth loss. Distinct degenerative changes were found in the left mandibular fossa. Taken together, these changes point to a lack of oral hygiene and perhaps frequent use of the teeth as a tool. The 25-30-year-old male from Pit 89 shows signs of stomatitis, carious lesions in the lower second molar and intravital tooth loss. The 40-50-year-old male 1927/2 reveals severe oblique dental wear, especially in the upper jaw, and some teeth with intravital chipping. The 30-35-year-old female from Grave 104 has a small caries lesion at the interface of the canine and the first premolar in the right upper jaw. Alveolar atrophy and alveolar pitting were further found in her dentition. Only the mandible is preserved of the dentition of the 40-60-year-old female from Grave 107; it shows multiple intravital tooth loss in the molars and a general alveolar atrophy.

\section{Degenerative joint disease}

Degenerative changes were noted in 14 individuals from Schleinbach, including two children. The 45-55-year-old female from Grave 11 shows a severe form of osteoarthrosis and osteoarthritis in the femora and tibiae of both knee joints. Distinct changes in the form of rim-like new bone formation at the margins and a loss of smoothness on the surface affected the distal femoral joints and the proximal tibial joints. A periarticular cyst was detected on the lateral 
part of the right tibia. None of the other large joints of this female show osteoarthritic changes. The cause of these changes might be both her severe case of gonarthrosis (genu valgum, 'knock knees') and the plane of the proximal tibial joint surfaces tilting downwards towards the dorsal side (Fig. 25). Risk factors for knee osteoarthritis include ageing, being female, excess weight and obesity, knee injuries, repetitive joint movements, reduced bone density, muscle weakness and joint laxity. Clinical radiography studies indicate that a high number of pregnancies, i.e. more than five or six, increases the risk for knee osteoarthritis. ${ }^{90}$

Degenerative changes in the form of new bone formation at the joint margins of both knees were also found in the 30-35-year-old male 31 from double burial 30/31. His tuberositas tibiae reveals distinct exostoses, and both femora show strong muscular changes at the linea aspera (similar to the adult male 60). The anterior-posterior diameter of the femora surpasses the sagittal one, indicating high mobility. ${ }^{91}$

The 40-55-year-old female from Pit 56 shows degenerative changes in several joints: the mandibular joints, the distal phalanges and the third to sixth cervical vertebrae. She further exhibits signs of deforming spondylosis in the second to fifth lumbar vertebrae. Taken together, the changes could point to the presence of chronic polyarthritis.

The acetabulum and the femoral head of the right hip joint of the 35-45-year-old male from Grave 59 is affected by severe coxarthrosis. The acetabulum is enlarged with new bone formation at the margin. The femoral head has developed a flattened, mushroom-like shape (Fig. 26), which may be caused by trauma.

The 30-35-year-old male from multiple burial 60 shows slight degenerative changes in the lumbar vertebrae, strong muscle attachments at the linea aspera of the femora and ridge-like exostoses in the superior part of the dorsal shaft of the tibiae (M. gastrocnemius and M. soleus). He, too, was of very robust stature.

Distinct degenerative changes to the left mandibular joint with enlarged facets were noted in the 30-45-year-old female from Pit 89.

The 27-35-year-old female from Grave 90 shows changes in both humeri from a pronounced attachment of the M. teres minor on the lateral side of the humeral heads and the M. brachialis in the upper part of the frontal humeri. These muscles are involved in external rotation and forearm flexion.

Slight degenerative changes in the form of osteophyte growth were found in the proximal part of the caput tali

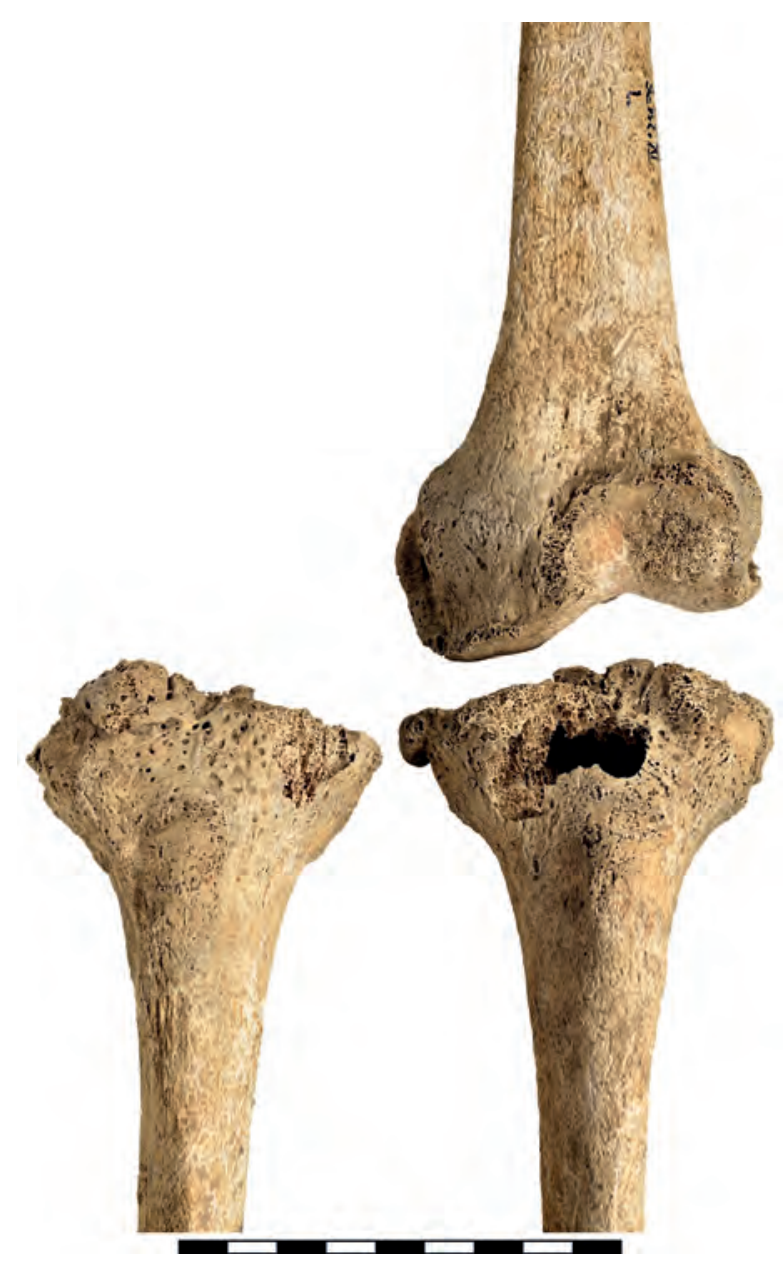

Fig. 25. Gonarthrosis in the 45-55-year-old female from Grave 11 (Photo: W. Reichmann, () NHM Vienna).

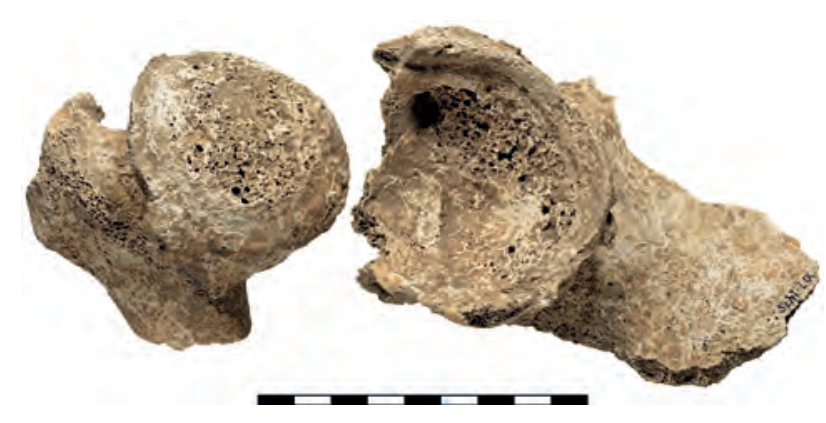

Fig. 26. Coxarthrosis in the 35-45-year-old male individual from Grave 59 (Photo: W. Reichmann, () NHM Vienna).

90 HeIdari 2011.

91 RufF et al. 2006. 
(facies articularis navicularis) in the 16-20-year-old female from Grave 106.

The 7-9-year-old child 1981 is another young individual with exostoses; changes were found in the lateral aspect of the dens axis.

The 40-60-year-old female from Grave 107 has degenerative changes in the second cervical vertebra, especially in the dens axis. Distinct degenerative changes (Stage 3) were found in the left femoral head, which appears very large. Distinct muscle attachments were found in the upper and lower limbs.

The individuals from the graves 109/1, 114 and 115 reveal slight degenerative changes in the large joints. Degenerative changes in the distal joint of the first phalanx of the right hand and osteophyte formation on the ventral side of the lumbar vertebrae 1-4 were recorded in the 40-50-yearold male 1927/2.

\subsection{Pelvic Features and Pelvic Pattern}

Pelvic features were recordable for 21 individuals from Schleinbach, including nine adult/mature males $(15,30,31$, $60,89 \mathrm{~B}, 108,109 / 1,115,1927 / 2)$, ten adult/mature females (9A, 11, 14, 29, 56, 90, 104/1, 106/1, 107, 1927/1) and two female adolescents (14: 15-18 years, 106/1: 16-20 years).

The region of the preauricular sulcus was preserved in 19 individuals: nine males and ten females (Tab. 8). Eight males showed the typically male, smooth shape, Stage 1, in this region..$^{92}$ This shape and stage was not found in any of the females. A weakly developed sulcus (Stage 2) was found in two females $(14,107)$ and one male $(89 \mathrm{~B})$. More strongly expressed preauricular sulci (moderate/strong expression, Stages 3/4) were exclusively found in females; Stage 3 in individuals 9A (45-55 years) and the adolescents 106/1 (16-20 years) and 1927/1 (18-21 years). Five females presented a large, well defined sulcus of Stage 4, three of them on both sides (29: 30-35 years, 56: 40-55 years, 90: 27-35 years), and two of them on one side (11: $45-55$ years, 104/1: 30-35 years)

The Schleinbach sample revealed a similar relation between the presence of a deep preauricular sulcus and short body height as at Unterhautzenthal. ${ }^{93}$ Half of the eight females with deep sulci (Stage 3 or 4 ) are shorter than or equal to the mean body height of $156 \mathrm{~cm}(11,90,104 / 1,106 / 1)$.

The margin of the auricular facet at the ilium was observable in 19 individuals: 11 females and eight males. Exostoses were found in six females (9A, 11, 32/2, 56, 90, 104/1) and three males $(60,108,1927 / 2)$. The region of the extended

92 BRŮŽEK 2002. - STECKEL et al. 2006.

93 Rebay-Salisbury et al. 2018, 96 and Fig. 15.

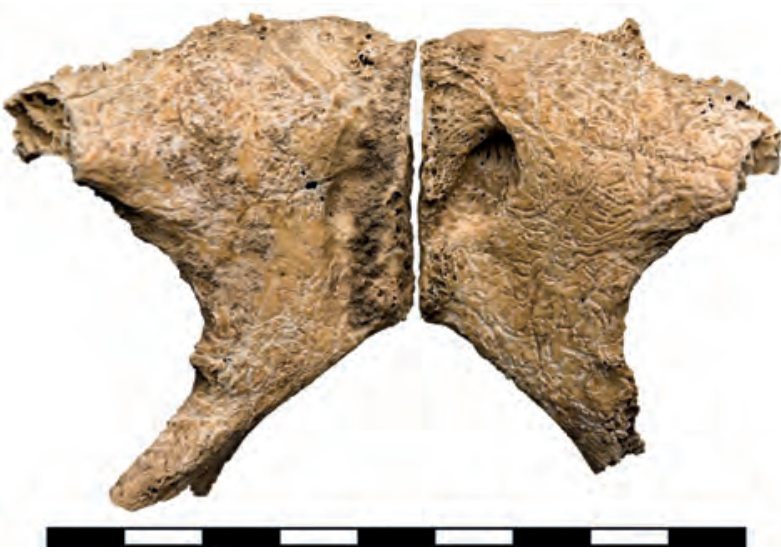

Fig. 27. Extended pubic tubercle and dorsal pitting of extraordinary size. - Left side: Deep long groove, $26.4 \mathrm{~mm}$ length, $6.2 \mathrm{~mm}$ width, $4.2 \mathrm{~mm}$ depth. - Right side: Deep oval pit, $13.4 \mathrm{~mm}$ diameter, $5.9 \mathrm{~mm}$ depth (Photo: W. Reichmann, () NHM Vienna).

pubic tubercle was available for assessment in six individuals: five females and three males. Two of the females revealed a distinct development of the tubercle (11: 45-55 years, 90: 27-35 years). A large, clearly defined extended tubercle (> $3 \mathrm{~mm}$, Stage 3, Fig. 27) and a sharp-edged pecten ossis pubis on the right side were present in the female from Grave 11, and a small extended tubercle (Stage 2) in the female from Grave 90. None of the males had an extension at the pubic tubercle location.

The dorsal symphyseal and adjacent area was observable in nine individuals: six females and three males. Four females $(11,29,56,90)$ had lesions on the dorsal pubic surface. The female from Grave 11 revealed an exceptionally large, oval-shaped dorsal pit in the centre of the right side of the dorsal pubic surface, extending into the upper part, although less deep (Stage 3, > $2 \mathrm{~mm}$, Fig. 27). The Stage 3 lesion on the left side of the dorsal pubic surface, in contrast, resembles a groove, is elongated and extends parallel to the symphysis. It covers nearly the whole surface from the upper to the lower third of the dorsal symphysis. Her severe bilateral gonarthrosis might be a cause of this severely pronounced form of dorsal pitting. None of the males had any changes to the dorsal pubic surfaces.

Exostoses on the ventral pubic surface were found in 3 of 6 females $(29,90,56)$ and 1 of 3 males $(60)$ for which the region could be examined. Lesions on the ventral pubic symphysis were present in 4 of 6 females $(11,29,90,56)$ and 1 in 3 males (30, an individual with a left-sided lumbosacral transitional vertebra).

In the detailed and systematic skeletal analysis of pelvic parts in the framework of the project, we noticed specific 


\begin{tabular}{|c|c|c|c|c|c|c|c|c|c|c|c|c|c|c|c|c|c|c|c|c|c|}
\hline & & Pelvic Pattern Index & ก̊? & $\begin{array}{l}\bar{b} \\
\dot{0}\end{array}$ & 응 & 우 & 竎 & 음 & 8 & $\begin{array}{l}\text { 우 } \\
\text { in }\end{array}$ & $\begin{array}{l}1 \\
\dot{0} \\
\dot{0}\end{array}$ & ָ̃ & 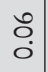 & $\begin{array}{l}n \\
n \\
0 \\
0\end{array}$ & $\tilde{?}$ & $\stackrel{m}{q}$ & $\stackrel{m}{\tilde{0}}$ & 8 & ৪ & $\stackrel{2}{\stackrel{2}{0}}$ & $\underset{7}{\overrightarrow{0}}$ \\
\hline & 으 & Number of calculated weightings & $m$ & $a$ & $\wedge$ & in & a & 으 & in & v & $\infty$ & $\sigma$ & 0 & 으 & ○ & in & $m$ & v & v & 으 & $a$ \\
\hline & 으 & Number of assessable pelvic features (10) & m & $a$ & $\wedge$ & in & $a$ & 으 & in & $\mathrm{N}$ & $\infty$ & $a$ & 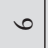 & 으 & ○ & in & $m$ & $\sim$ & $\mathrm{N}$ & 으 & $a$ \\
\hline & & Corr. changes at apex of iliac auricular facet left & - & - & - & ○ & - & - & - & O & - & - & - & - & - & - & 0 & 0 & o & - & - \\
\hline & & Corr. changes at apex of iliac auricular facet right & 0 & 0 & - & - & - & - & $\neg$ & - & 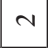 & - & - & $\rightarrow$ & - & $\sim$ & - & 0 & O & N & - \\
\hline \multirow[t]{3}{*}{ 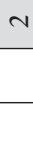 } & - & Corr. changes at apex of iliac auricular facet & - & - & - & - & - & - & - & - & v & - & - & - & - & 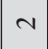 & - & 0 & - & N & - \\
\hline & & Sacral preauricular notch left & 0 & 0 & o & ○ & - & - & $\neg$ & 0 & - & - & 0 & - & - & - & 0 & 0 & o & o & - \\
\hline & & Sacral preauricular notch right & 0 & - & O & - & $\neg$ & $\neg$ & $\neg$ & 0 & 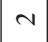 & - & - & $\sim$ & O & 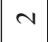 & 0 & 0 & 0 & - & - \\
\hline \multirow[t]{3}{*}{$m$} & - & Sacral preauricular notch & 0 & - & o & - & - & - & - & 0 & $v$ & - & - & N & - & $\mathrm{n}$ & 0 & 0 & 0 & - & - \\
\hline & & Sacral preauricular extension left & 0 & O & O & O & a & - & $\neg$ & 0 & - & - & ० & - & - & - & 0 & 0 & O & O & - \\
\hline & & Sacral preauricular extension right & 0 & v & o & - & 2 & - & - & 0 & - & - & - & - & ○ & - & 0 & 0 & o & v & - \\
\hline \multirow[t]{3}{*}{$m$} & - & Sacral preauricular extension & 0 & 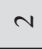 & 0 & - & a & - & - & 0 & - & - & - & - & - & - & 0 & 0 & o & v & - \\
\hline & & Os sacrum margo auricularis groove left & 0 & 0 & O & ○ & 0 & - & 0 & 0 & - & 0 & - & - & - & - & 0 & 0 & o & $\neg$ & 0 \\
\hline & & Os sacrum margo auricularis groove right & 0 & 0 & O & ○ & 0 & - & 0 & 0 & 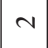 & 0 & - & $\neg$ & ○ & - & 0 & 0 & o & v & 0 \\
\hline \multirow[t]{3}{*}{ + } & - & Os sacrum margo auricularis groove & 0 & 0 & o & ○ & 0 & $\neg$ & 0 & 0 & 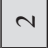 & 0 & $\rightarrow$ & - & - & 0 & 0 & 0 & 0 & v & 0 \\
\hline & & Ventral pubic surface, lesion left & 0 & v & - & ○ & a & 2 & 0 & 0 & 0 & - & o & $N$ & ○ & 0 & 0 & o & o & - & 0 \\
\hline & & Ventral pubic surface, lesion right & 0 & 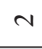 & - & ○ & a & 2 & 0 & 0 & $\sim$ & - & O & $N$ & ○ & 0 & 0 & 0 & O & ○ & - \\
\hline \multirow[t]{3}{*}{$\sim$} & - & Ventral pubic surface, lesions & 0 & 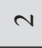 & - & ○ & w & s & 0 & 0 & 0 & - & ○ & $N$ & O & 0 & 0 & 0 & 0 & - & - \\
\hline & & Ventral pubic surface, exostoses left & 0 & - & $\neg$ & ○ & N & - & 0 & 0 & 0 & - & ○ & $N$ & ○ & 0 & 0 & 0 & 0 & - & 0 \\
\hline & & Ventral pubic surface, exostoses right & 0 & - & - & o & a & - & 0 & 0 & $\sim$ & $\sim$ & o & $\sim$ & 0 & 0 & 0 & 0 & o & o & - \\
\hline \multirow[t]{3}{*}{$\sim$} & - & Ventral pubic surface, exostoses & 0 & - & - & o & 4 & - & 0 & 0 & v & 4 & o & N & 0 & 0 & 0 & 0 & 0 & - & - \\
\hline & & Dorsal pubic surface left & 0 & $n$ & - & ○ & - & - & 0 & 0 & 0 & 0 & ○ & $N$ & O & 0 & 0 & 0 & 0 & - & 0 \\
\hline & & Dorsal pubic surface right & 0 & $m$ & $\neg$ & ○ & 2 & - & 0 & 0 & $\sim$ & - & ○ & $\neg$ & O & 0 & 0 & 0 & o & ○ & - \\
\hline \multirow[t]{3}{*}{$m$} & $\rightarrow$ & Dorsal pubic surface & 0 & $m$ & - & ○ & 2 & - & 0 & 0 & $v$ & - & o & N & O & 0 & 0 & 0 & o & - & - \\
\hline & & Extended tuberculum pubicum left & 0 & N & - & ○ & $\neg$ & - & 0 & 0 & 0 & - & ○ & $N$ & ○ & 0 & 0 & 0 & O & - & 0 \\
\hline & & Extended tuberculum pubicum right & 0 & $n$ & - & ○ & - & - & 0 & 0 & 0 & 0 & o & $\circ$ & ○ & 0 & 0 & 0 & o & ○ & - \\
\hline \multirow[t]{3}{*}{$m$} & - & Extended tuberculum pubicum & 0 & $m$ & - & ○ & - & - & 0 & 0 & 0 & - & ○ & $\sim$ & ○ & 0 & 0 & 0 & o & - & - \\
\hline & & Exostoses facies auricularis left & v & 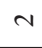 & O & ○ & $\neg$ & - & - & 0 & 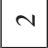 & 0 & $\rightarrow$ & $N$ & $N$ & - & 0 & - & O & - & 0 \\
\hline & & Exostoses facies auricularis right & 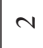 & 0 & - & - & $\neg$ & - & - & $\sim$ & $\sim$ & $\sim$ & - & $N$ & ○ & - & $\sim$ & $\rightarrow$ & o & - & $N$ \\
\hline \multirow[t]{3}{*}{ v } & - & Exostoses facies auricularis & 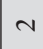 & v & - & - & - & - & - & 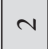 & 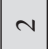 & v & - & $\sim$ & N & - & v & - & o & - & $N$ \\
\hline & & Preauricular sulcus left & v & 4 & - & O & t & - & - & 0 & + & 0 & - & + & + & $m$ & 0 & - & - & 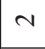 & 0 \\
\hline & & Preauricular sulcus right & $m$ & 0 & v & - & t & - & $\neg$ & 0 & + & - & $N$ & + & ○ & $m$ & - & - & - & $m$ & - \\
\hline t & - & Preauricular sulcus & $m$ & t & v & - & t & - & - & 0 & + & - & $\sim$ & + & + & $m$ & - & - & - & $m$ & - \\
\hline \multirow{5}{*}{ 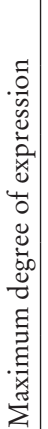 } & \multirow{5}{*}{ 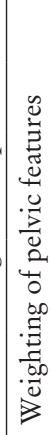 } & Femoral length (mm) & 尔 & $\frac{\infty}{f}$ & $\stackrel{\sigma}{m}$ & $\stackrel{\sim}{q}$ & $\stackrel{\stackrel{n}{p}}{q}$ & 卓 & $\stackrel{+}{\stackrel{+}{f}}$ & 0 & 0 & $\vec{b}$ & ० & oे & ○ & $\begin{array}{l}\infty \\
\text { o } \\
\end{array}$ & 0 & $\underset{⿱ 亠 䒑}{+}$ & o & o & $\hat{\tilde{f}}$ \\
\hline & & Body height femur (cm, RuFF et al. 2012) & 3 & $\stackrel{2}{2}$ & $\stackrel{\circ}{10}$ & $\vec{\sigma}$ & $\overline{6}$ & $\tilde{6}$ & 0 & o & $\overrightarrow{0}$ & \begin{tabular}{|l|}
$\infty$ \\
0 \\
--1 \\
\end{tabular} & ० & $\stackrel{\square}{n}$ & กิ & $\stackrel{n}{n}$ & $\stackrel{9}{0}$ & $\overrightarrow{0}$ & $\stackrel{n}{\triangleq}$ & 0 & 0 \\
\hline & & Sex & 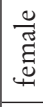 & 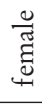 & 㫕 & 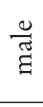 & 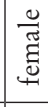 & 光 & $\frac{\tilde{\Xi}}{\tilde{\Xi}}$ & 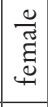 & 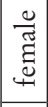 & 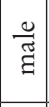 & $\frac{\stackrel{\Xi}{\Xi}}{\tilde{\Xi}}$ & 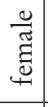 & 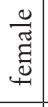 & 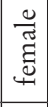 & 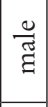 & 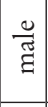 & $\frac{\stackrel{\Xi}{\Xi}}{\Xi}$ & 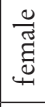 & $\frac{\mathscr{\Xi}}{\stackrel{\Xi}{\Xi}}$ \\
\hline & & Age & $\begin{array}{l}n \\
1 \\
1 \\
+ \\
+\end{array}$ & $\begin{array}{l}10 \\
i n \\
1 \\
+ \\
\end{array}$ & $\begin{array}{l}\infty \\
1 \\
n \\
-1\end{array}$ & $\frac{\stackrel{\sim}{N}}{\stackrel{\sim}{\sim}}$ & $\begin{array}{l}n \\
\tilde{1} \\
0 \\
m\end{array}$ & 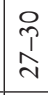 & $\begin{array}{l}n \\
\tilde{\rho} \\
\end{array}$ & $\begin{array}{l}\text { 우 } \\
\text { in } \\
\text { n }\end{array}$ & $\begin{array}{l}10 \\
\hat{1} \\
0 \\
+ \\
\end{array}$ & $\begin{array}{c}n \\
\tilde{1} \\
\hat{\sim}\end{array}$ & $\begin{array}{l}0 \\
\tilde{1} \\
\end{array}$ & $\begin{array}{l}n \\
\hat{1} \\
\hat{\imath}\end{array}$ & $\begin{array}{l}n \\
\hat{1} \\
0 \\
e\end{array}$ & $\begin{array}{l}0 \\
i \\
1 \\
-\end{array}$ & $\begin{array}{l}\text { 우 } \\
0 \\
\text { r }\end{array}$ & $\begin{array}{l}\text { o } \\
\text { 1 } \\
\text { m }\end{array}$ & $\begin{array}{l}\text { o } \\
1 \\
0 \\
\text { m }\end{array}$ & $\begin{array}{l}\vec{\sim} \\
\infty \\
-\end{array}$ & $\begin{array}{l}\text { ㅇ } \\
\text { 1 } \\
\text { o } \\
\end{array}$ \\
\hline & & Individual & 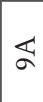 & $\exists$ & \pm & $\stackrel{10}{=}$ & নे & 足 & $\bar{m}$ & r & in & 8 & $\stackrel{\infty}{\infty}$ & ৪ & $\begin{array}{l}\overrightarrow{1} \\
\underset{0}{0} \\
-1\end{array}$ & 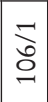 & $\stackrel{\infty}{0}$ & $\begin{array}{l}\vec{a} \\
\hat{0} \\
-\end{array}$ & $\stackrel{\operatorname{Ln}}{=}$ & 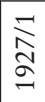 & 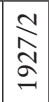 \\
\hline
\end{tabular}



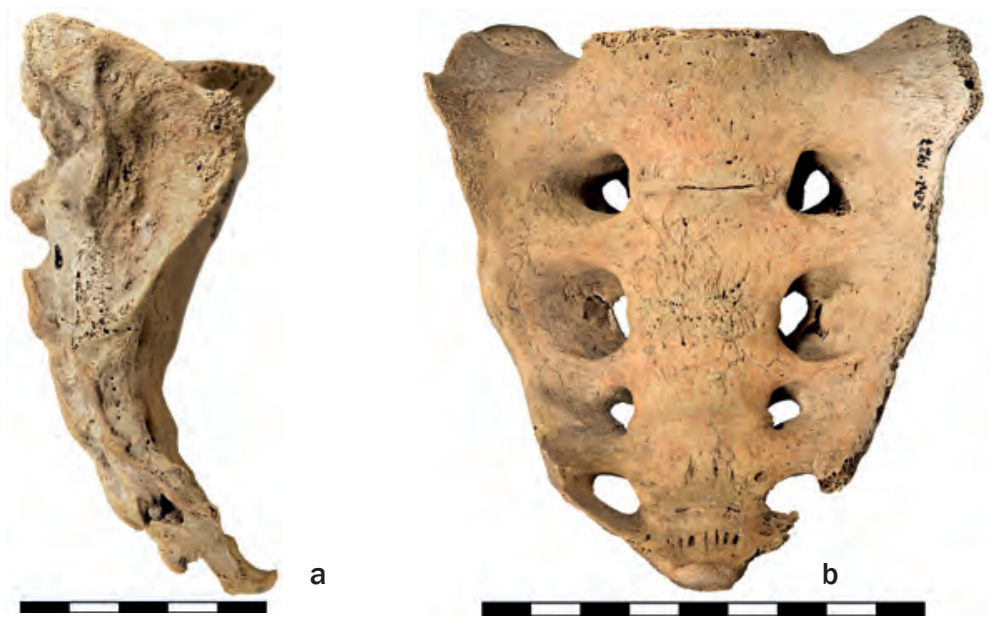

Fig. 28. Preauricular extension to the right sacrum of the 18-21-year-old woman 1927/1. - a. Right lateral view. - b. Frontal view (Photo: W. Reichmann, (C) NHM Vienna).

changes at the ventrosuperior margin (ventral apex) of the ala ossis sacri, adjacent to the auricular facet at the sacrum. The first morphological modification termed sacral preauricular extension is a ventrally pointing flat osseous structure, and it frequently has a corresponding facet at the ilium. The sacral preauricular extension is delineated from the auricular surface by a subtle line, can vary in size and usually occurs on one or on both sides of this predilection site at the ventral apex of the sacrum. The changes are very likely caused by increased pressure at this location, ligament laxity and positional changes during pregnancies and birthing events. The second structure is termed the sacral preauricular notch, which describes a loss of convexity at this location. It may be accompanied by a recess at the ilium and stand in a causal relationship with giving birth at a young age. ${ }^{94}$ The relevant region at the sacrum, the ventral apex of the ala ossis sacri, was present in seven females and six males from Schleinbach. A sacral preauricular extension was found in three females: the 45-55-year-old from Grave 11 and the 18-21-year-old from 1927/1 (Fig. 28) have a small sacral preauricular extension on the one present side, the 30-35-year-old from Grave 29 on both sides. No male individual had similar changes in this region. ${ }^{95}$

A sacral preauricular notch was noticed in 3 out of 8 females at Schleinbach (56: 45-55 years, 90: 27-35 years, 106/1: 16-20 years) and in none of the 6 observable males

94 Pany-Kucera et al. 2019.

95 At the contemporaneous Early Bronze Age site Unterhautzenthal, a bilateral sacral preauricular extension was found in 2 of $11 \mathrm{ob}-$ servable females (93: large extension, 88: small extension). from Schleinbach. The sacral preauricular notch at the right sacrum of the 45-55-year-old female in Grave 90 is particularly large (Fig. 29). The sacral preauricular notch of the female from Grave 56 may relate to the partially healed fractures in the sacrum. A facet at the ilium, corresponding to the extensions and notches, was recorded in 3 of $10 \mathrm{ob}-$ servable females (56, 106/1 and 1927/1) and none of the 8 observable males.

The region of the margo auricularis groove at the sacrum adjacent to the preauricular sulcus was preserved in five females and two males; a groove at the lateral margin of the os sacrum was present in two females. In both cases, changes affected only the right sides, whilst the other sides were normal (56, 1927/1).

An interesting observation is that some females combine several distinctly expressed features in the pelvis and sacrum bones. If some of the features are particularly pronounced, we suggest the term 'Pelvic Pattern'. At Schleinbach, we observed such patterns in the females 9A, 11, 29, 56, 90, 104/1, 106/1 and 1927/1 (Tab. 8).

The 45-55-year-old female from Grave 9 (9A) shows a moderately developed preauricular sulcus (Stage 3 on the right side, left side is eroded) and some exostoses located at the upper margin of the facies auricularis. She was found with some cranial fragments and an upper first incisor of a c. 1.5-year-old child (9B).

The 45-55-year-old female from Grave 11 has a combination of a deep preauricular sulcus (Stage 4 on the left side), developed exostoses at the margin of the auricular facet of the ilium, an extended pubic tubercle (Stage 3 on the right side), severe dorsal pubic pitting (Stage 3 ), and a sacral 

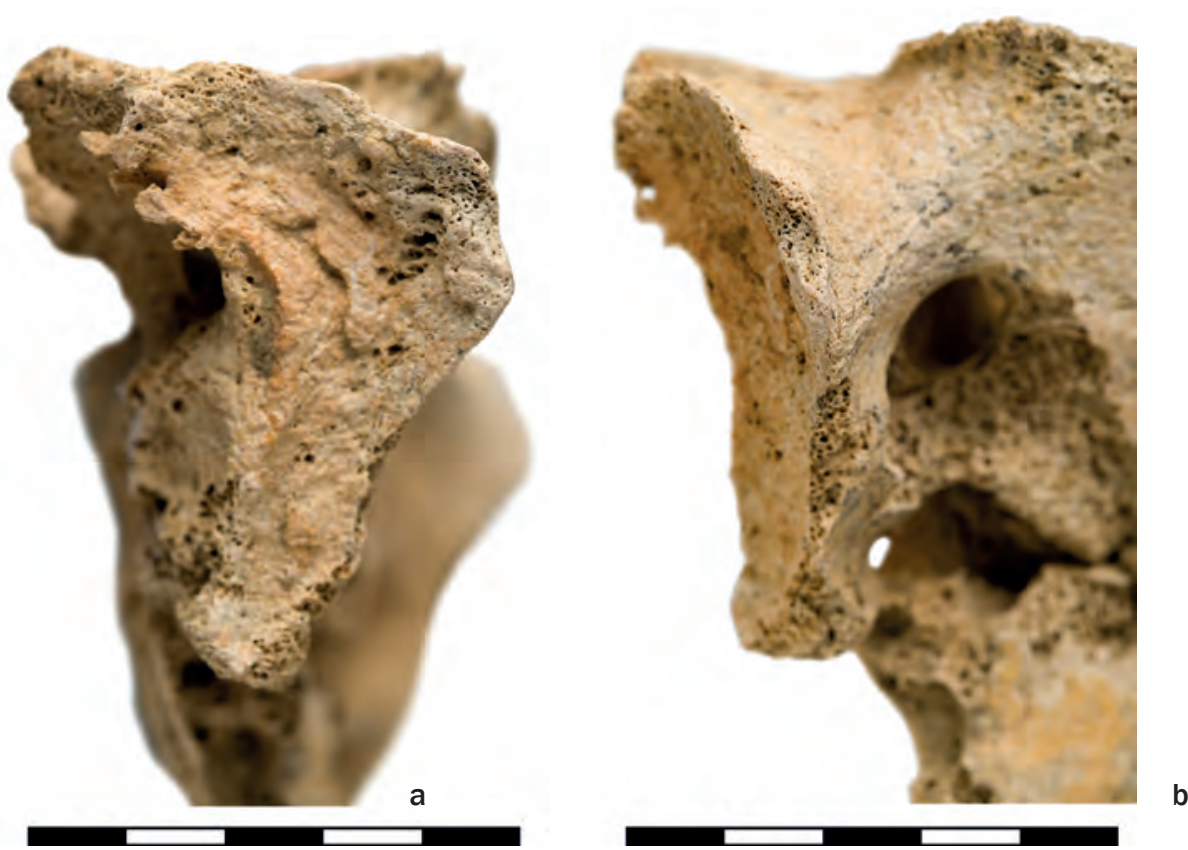

Fig. 29. Sacral preauricular notch in the right sacrum of the 45-55-year-old female in Grave 90. - a. Right lateral view. - b. Frontal view (Photo: W. Reichmann, (C NHM Vienna).

preauricular extension at the right ventral apex of the ala ossis sacri. Severe gonarthrosis was noticed in both her knee joints, with severe exostotic new bone formation around the joint surfaces of the distal femora and proximal tibiae (see Fig. 25).

The 30-35-year-old female from Grave 29 combines deep, delimited preauricular sulci (Stage 4, true preauricular groove), a bilateral sacral preauricular extension without clearly corresponding facets at the ilium, dorsal pubic pitting (Stage 2) to the right pubic bone, and distinct lesions and exostoses on the ventral side. Irregular exostotic structures are further visible at the location of the extended pubic tubercle, but a real extension did not form. A bilateral accessory sacroiliac articulation formed at the upper dorsal end of the facies auricularis. This modification is an elongated facet, somewhat elevated and delimited from the joint surface, pointing in the dorsal direction (right side: $16.5 \mathrm{~mm}$, left side: $13.6 \mathrm{~mm}$ ). This facet corresponds to a structure at the ilium, which is visible on the right side, but eroded on the left (Fig. 30). It may have formed in response to supporting increased weight.

The 40-55-year-old female from Pit 56 has a strongly developed preauricular sulcus (Stage 4), exostoses at the margin of the facies auricularis of the ilium, dorsal pubic pitting on the right side, ventral exostoses and lesions at the pubis, a margo auricularis groove (Stage 2) and a sacral preauricular notch on the right side. She has multiple sacrum fractures

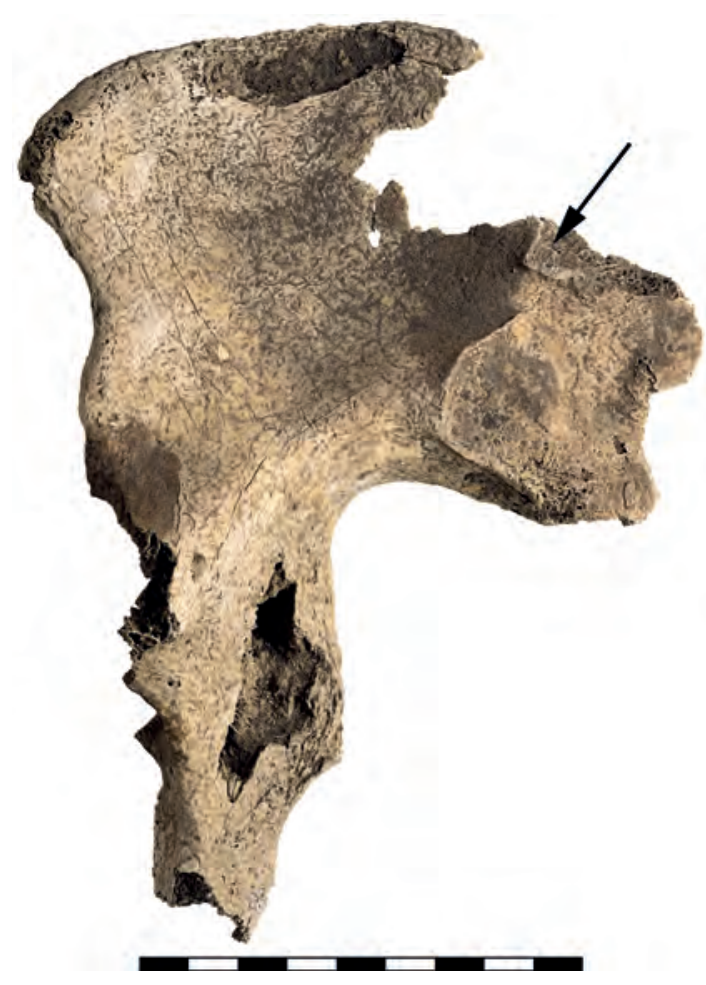

Fig. 30. Accessory sacroiliac articulation in the 30-35-year-old female from Grave 29 (Photo: W. Reichmann, (C) NHM Vienna). 
in different stages of healing. The upper part of the right auricular facet is completely remodelled. A small exostosis formed at the right ilium in the frontal part of the ala ossis ilii, which originates from the iliac side and extends over the sacroiliac joint. Degenerative changes in the lumbar vertebrae, in the form of a deforming spondylosis (L2-L5) and a probable compression trauma in $\mathrm{L} 3$, are probably related to her multiple sacrum fractures. Additionally, we noticed bilateral accessory sacroiliac articulations, which are ascribed to the frequent carrying of loads on the back, particularly babies, as deduced from this custom in an East African group. ${ }^{96}$ Ridges and exostoses on the dorsal side of her iliac bones stem from a more robust attachment of the gluteal muscles in line with the pelvic modifications.

The Pelvic Pattern of the 27-35-year-old female from Pit 90 includes a preauricular sulcus Stage 4, dorsal pitting on the left side (Stage 2), an extended pubic tubercle on the left side (Stage 2), distinct exostoses on the ventral pubic surface, and a sacral preauricular notch at the ventral apex of the left ala ossis sacri. Four exostoses of slightly different sizes and the form of spiculae were found adjacent to the left dorsal end of the iliac auricular facet; currently, these cannot be conclusively interpreted. Distinct osteophyte growth and extensive inflammatory changes were recorded at the lumbosacral junction (L5/S1), which may indicate that she suffered from a lumbar disc herniation. In addition, her right femur is shorter than the left by $12 \mathrm{~mm}$. The attachment site of the oblique muscles at the iliac crest shows a distinctly developed ridge on the right side; this muscle is involved in the tension of the abdominal musculature.

The 30-35-year-old female found in Grave 104/1 reveals a combination of a bilateral, deep preauricular sulcus Stage 4 and exostoses along the margin of the iliac auricular facet (forming a sharp-edged ridge at the ventral apex and lower part of the margin on both sides). Moderate osteophyte growth was noticed at the front of the lumbosacral junction (only L 5 preserved, most other pelvic features were not observable). The humerus of a 7-8-month-old foetus/neonate was found with the bones of this female.

The Pelvic Pattern of the 16-20-year-old adolescent female from Grave 106/1 consists of a preauricular sulcus Stage 3 on the right and Stage 2 on the left side, as well as a sacral preauricular notch at the ventral apex of the right ala ossis sacri. A corresponding facet in the shape of a depression is visible adjacent to the ventral apex of the auricular facet at the right iliac bone. The two modifications form a recess at the terminal line, best visible when the bones are held together (Fig. 31). We further noticed spina bifida occulta at the lower dorsal end of the sacrum (S4/S5).

96 TrotTER 1964.

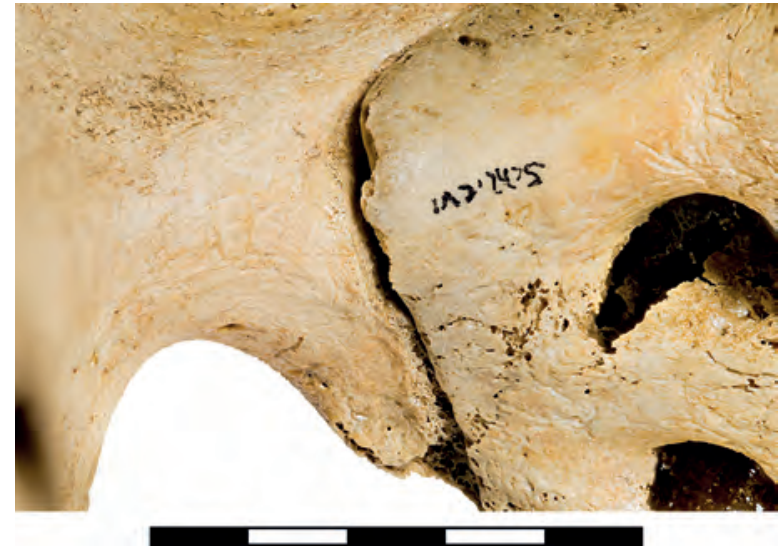

Fig. 31. Recess at the level of the terminal line between sacrum and ilium in the 16-20-year-old female from Grave 106/1 (Photo: W. Reichmann, () NHM Vienna).

The 18-21-year-old female 1927/1 shows a combination of a preauricular sulcus Stage 3 on the right/Stage 2 on the left side with a unilateral sacral preauricular extension on the right (with inflammatory signs) as well as a margo auricularis groove on the right side (see Fig. 10). The skeleton of this female was found with other human remains, including the right femur of a 4-6-month-old child (1927/4).

It is interesting to note that two different expressions of the recently described morphological changes at the sacrum occur in young females such as the latter two. This might point to a young age of first motherhood. ${ }^{97} \mathrm{Two}$ females of middle age (90: 27-35 years; 104/1: 30-35 years) with pelvic patterns show degenerative changes combined with inflammatory signs in the lumbar vertebrae. Clinical studies on females treated for lower back pain in pregnancy indicate that increased pelvic relaxation causes irritations in the lumbosacral region. ${ }^{98}$ A pattern with distinctly expressed pelvic features was not found in any of the nine observable male individuals from Schleinbach.

In order to compare the severity of pelvic changes to the archaeological contexts, we assigned a Pelvic Pattern Index (PPI) to the ten females and nine males with at least two assessable features (Tab. 8). Since little is known about the relevance of the features, they are not weighted; only the number of accessible features and the degree of expression is taken into account. High Pelvic Pattern Index numbers correspond to an accumulation of significant changes in the pelves. The women with the highest values were buried in Grave 11 (45-55 years, PPI 0.61, nine recordable features, 'rich' grave), Grave 29 (30-35, PPI 0.44, nine recordable

97 Pany-Kucera et al. 2019.

98 Hagen 1974. 


\begin{tabular}{|c|c|c|c|c|c|c|c|c|c|c|}
\hline Histo ID & Individual & \multicolumn{2}{|c|}{ Morphological } & FDI & Full eruption age & \multicolumn{2}{c|}{ TCA counts in 3 areas } & \multicolumn{2}{l|}{$\begin{array}{c}\text { Width of cementum/ } \\
\text { width between lines }\end{array}$} \\
\hline & & Sex & Age & & & Mean & SD & Age & Mean & Age \\
\hline 5627 & $9 \mathrm{~A}$ & female & $45-55$ & 41 & 7.5 & 20.0 & 4.1 & $27.5 \pm 5$ & 20.1 & $27.6 \pm 5$ \\
\hline 5629 & 30 & male & $27-30$ & 21 & 7.5 & 30.5 & 0.5 & $38.0 \pm 5$ & 31.9 & $39.4 \pm 5$ \\
\hline 5630 & 31 & male & $30-35$ & 25 & 12.5 & 21.3 & 2.1 & $33.8 \pm 5$ & 22.5 & $35 \pm 5$ \\
\hline Schl G 56 & 56 & female & $40-55$ & 44 & 11.5 & 15.67 & 0.47 & $27.2 \pm 5$ & 35.75 & $47.2 \pm 5$ \\
\hline 5628 & 60 & male & $30-35$ & 35 & 12.5 & - & - & & 26.2 & $38.7 \pm 5$ \\
\hline 5654 & $1983 / 61$ & undet. & $20-40$ & 24 & 11.5 & 16.3 & 1.2 & $27.8 \pm 5$ & 13.4 & $24.9 \pm 5$ \\
\hline 5655 & $1983 / 71$ & undet. & $16-18$ & 21 & 7.5 & 6.7 & 1.7 & $14.2 \pm 5$ & 9.2 & $16.7 \pm 5$ \\
\hline
\end{tabular}

Tab. 9. Results of the tooth cementum annulation analysis of seven individuals from Schleinbach. - The table includes morphological sex and age estimation, the type of tooth (FDI World Dental Federation) and the average age of its alveolar eruption. The means and standard deviations of the TCA counts were calculated from three independent counts of subsequent cross-sections of the middle third of the dental roots. The alternative method divides the width of the cementum by the mean distance between lines. Age at death is calculated by adding the means of counts or measurements to the tooth eruption age; an error range of \pm 5 years is assumed.
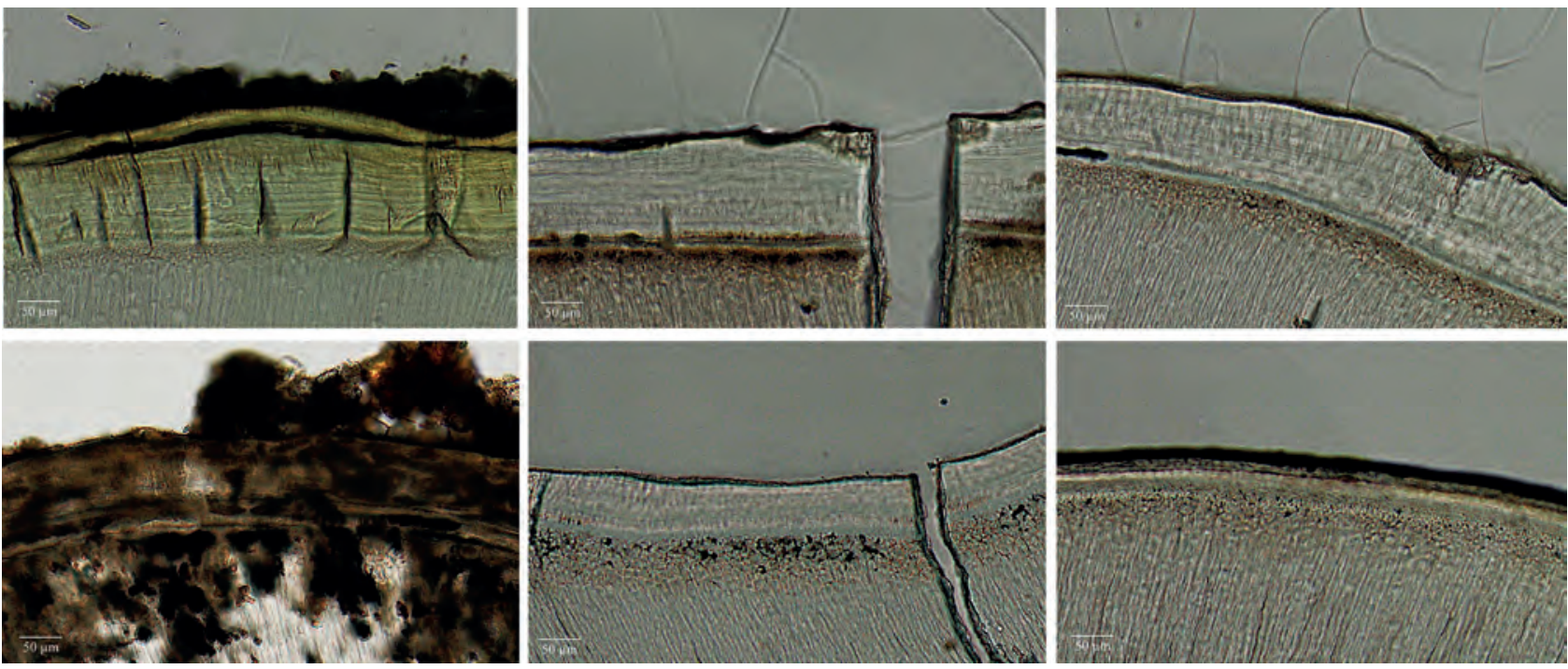

Fig. 32. Thin sections of dental roots of six individuals from Schleinbach: 9, 30, 31, 60, 1983/Grube 61 and 1983/Grube 71 (Photos: B. Rendl, (c) Medical University of Vienna).

features, 'average' grave), Pit 56 (40-55, PPI 0.67, nine observable features, 'poor' pit burial) and Grave 90 (27-35, PPI 0.55 , ten recordable features, 'rich' grave). We found a weak positive correlation between the Pelvic Pattern Index and the social status of the individuals $(r=0.15$, if poor $=0$, average $=50$, rich $=100$ ), between the Pelvic Pattern Index and age $(r=0.25)$ and the Pelvic Pattern Index and body height $(r=0.18)$.

\subsection{Tooth Cementum Annulation Analysis}

We arrived at very similar results with both methods of analysing tooth cementum annulations - counting and interpolating (Tab. 9, Fig. 32). The difference in age estimation via counting all tooth cementum lines and the extrapolation method is less than three years in five individuals. Only the 40-55-year-old female from Pit 56 was estimated at $26.2 \pm 5$ years with counting and $46.2 \pm 5$ years applying the interpolation method, which matches the morphological age estimation.

The results of the tooth cementum annulation analysis (TCA) of two individuals did not match the morphological age estimation. The 45-55-year-old female from Grave 9 appeared younger (TCA age 21.5-31.6 years), whereas the 27-30-year-old male 30 from the double burial $30 / 31$ 
appeared older (TCA age 32-43.4 years) than first estimated. The age ranges of the remaining individuals overlap. At present, we cannot conclusively explain the differences, but would like to highlight the potential of exploring the differences to understand how people age.

\subsection{Kinship Analysis in Multiple Burials via Mitochondrial DNA}

The two male individuals buried close together in Grave 30/31 share the same haplotype belonging to haplogroup $\mathrm{H}+152$; this provides evidence that they may have been (closely) related via the maternal line, e.g. they could have been brothers or cousins.

Of the four individuals buried in Pit 60, the 8-9-yearold child 60A and the 3-4-year-old child 60C share the same haplotype (haplogroup U2e3a). Again, this points to a (close) maternal relationship between these two individuals, whereas the other individuals in the pit are not maternally related to anyone else in this sample and belong to haplogroups H2a1 and J1c2 (Tab. 10).

In terms of population genetics, haplogroup $\mathrm{H}$ is the most common mtDNA clade in Europe (present in about $40 \%$ of today's Europeans); H2 is a common west Eurasian lineage with concentrations in eastern Europe and the Caucasus, central and western Asia. The subclade H2a1 has recently been found in 3 of 80 genetically typed individuals from the Lech River Valley in Bavaria, ${ }^{99}$ and is present once in samples from Bronze Age Hungary. ${ }^{100}$

Haplogroup U2 is not as common as $\mathrm{H}$ in Europe today and shows higher abundance in the Caucasus. Archaeologically, U2 is considered steppe ancestry, appearing more frequently in samples after the Neolithic. Haplogroup J is a common component of the west Eurasian gene pool today, probably of Near Eastern origin. ${ }^{101} \mathrm{~J} 1 \mathrm{c}$ is associated with the spread of Neolithic farmers from Anatolia via the Balkans. ${ }^{102} \mathrm{~J} 1 \mathrm{c} 2$ has been found at the LBK site Karsdorf, ${ }^{103}$ and in an Early Bronze Age sample from the Bavarian Lech Valley. ${ }^{104} \mathrm{~J} 1 \mathrm{c} 2$ has further recently been found in five Late Bronze Age/Iron Age samples from the northern Iberian Peninsula, ${ }^{105}$ and is part of Richard III's genome. ${ }^{106}$

99 Knipper et al. 2017.

100 Allentoft et al. 2015, suppl. tab. 14.

101 Chyleński et al. 2017.

102 Mathieson et al. 2015.

103 BRANDT et al. 2013.

104 Knipper et al. 2017.

105 NÚÑEZ et al. 2016.

106 KING et al. 2014.

\subsection{Proteomic Sex Identification in Selected Juvenile Individuals}

The sex of the three children buried together with the 30-35-year-old male in Pit 60 was determined as male for the 8-9-year-old child 60A, and female for the 12-yearold child $60 \mathrm{~B}$ as well as the $3-4$-year-old child $60 \mathrm{C} .{ }^{107}$ The 5-6-year-old victim of violence from Feature 1981/Grube 3 was male. ${ }^{108}$

\section{Discussion and Conclusion}

The detailed osteological examination of the skeletal material comprising 62 individuals, of which 27 were subadults, in combination with supplementary ${ }^{14} \mathrm{C}$, TCA, mtDNA, peptide and isotope analysis allows new insights into the social fabric of the Early Bronze Age community of Schleinbach.

The clear social differentiation between persons buried in 'regular' graves and those deposited in former storage pits, albeit not unusual in the cultural context, ${ }^{109}$ remains perplexing. Social differentiation may entail not only the acquisition of land and material wealth - although this is the easiest to see and quantify for archaeologists - but also the domination of people and the exploitation of their labour, including the bearing of children.

Formal burial in one of the two grave groups includes the placement of bodies in a flexed or extended position, a uniform orientation, and the inclusion of grave goods, even if graves were often later reopened and metal grave goods were removed. The deposition of bodies and body parts in former storage pits is less formal: the bodies appear placed without care or empathy and are often found in secondary, disarticulated positions and without grave goods. Bio-archaeological indicators of mistreatment and marginalization ${ }^{110}$ of individuals are plentiful at Schleinbach.

Most striking at this site is the high prevalence of traces of violence. Small-scale communities such as Schleinbach in the Early Bronze Age may be less peaceful than often imagined; life in the settlement may include frequent ambushes and raids, the taking of captives, and the domination of some people by others. ${ }^{111}$ The trauma patterns observed in each of those individuals testify to accidents and interpersonal violence.

The unhealed cranial fractures point to a high level of interpersonal violence. At least six individuals (16.2 \%)-three men, two children and one woman - died from fatal injuries

107 WENINGER 1954a, 16-17 had suggested the male sex for the two older children (60A, 60B).

108 Rebay-Salisbury et al. 2020.

109 E.g. Lauermann 1992. - MÜller-Scheessel et al. 2013.

110 Martin 2008. - Martin, Harrod, Fields 2010.

111 Cameron 2016 


\begin{tabular}{|c|c|c|c|c|c|c|}
\hline Grave & 30 & 31 & 60 & $60 \mathrm{~A}$ & $60 \mathrm{~B}$ & $60 \mathrm{C}$ \\
\hline Description & Male & Male & Male & Infant & Infant & Infant \\
\hline Age & $27-30$ & $30-35$ & $30-35$ & $8-9$ & $11.5-12.5$ & $3-4$ \\
\hline FDI & 36 & 47 & 17 & 36 & 47 & 55 \\
\hline Mill/drill & Mill & Mill & Mill & Drill & Drill & Drill \\
\hline mtGE (67 bp) & 147.7 & 305.1 & 98.4 & 56.1 & 18.0 & 28.1 \\
\hline Haplogroup & $\mathrm{H}+152$ & $\mathrm{H}+152$ & $\mathrm{H} 2 \mathrm{a} 1$ & U2e3 (U2e3a) & $\mathrm{J} 1 \mathrm{c} 2$ & U2e3 (U2e3a) \\
\hline \multirow[t]{36}{*}{ Mitotype } & $152 \mathrm{C}$ & $152 \mathrm{C}$ & $263 G$ & $73 \mathrm{G}$ & $73 G$ & $73 G$ \\
\hline & $263 \mathrm{G}$ & $263 G$ & $315.1 \mathrm{C}$ & $152 \mathrm{C}$ & $185 \mathrm{~A}$ & $152 \mathrm{C}$ \\
\hline & $315.1 \mathrm{C}$ & $315.1 \mathrm{C}$ & $750 \mathrm{G}$ & $217 \mathrm{C}$ & $188 \mathrm{G}$ & $217 \mathrm{C}$ \\
\hline & $750 \mathrm{G}$ & $750 \mathrm{G}$ & $8860 G$ & $263 G$ & $228 \mathrm{~A}$ & $263 G$ \\
\hline & $(4769 G)$ & $4769 \mathrm{G}$ & $16354 \mathrm{~T}$ & $315.1 \mathrm{C}$ & $263 G$ & $315.1 \mathrm{C}$ \\
\hline & $8860 G$ & $8860 \mathrm{G}$ & & $394 \mathrm{~T}$ & $295 \mathrm{~T}$ & $394 \mathrm{~T}$ \\
\hline & $15326 \mathrm{G}$ & $15326 \mathrm{G}$ & & $508 \mathrm{G}$ & $315.1 \mathrm{C}$ & $508 \mathrm{G}$ \\
\hline & $16519 \mathrm{C}$ & $16519 \mathrm{C}$ & & $524.1 \mathrm{~A}$ & $462 \mathrm{~T}$ & $524.1 \mathrm{~A}$ \\
\hline & & & & $524.2 \mathrm{C}$ & $489 \mathrm{C}$ & $524.2 \mathrm{C}$ \\
\hline & & & & $750 G$ & $750 \mathrm{G}$ & $750 \mathrm{G}$ \\
\hline & & & & $1811 G$ & $14766 \mathrm{~T}$ & $5390 \mathrm{G}$ \\
\hline & & & & $3170 \mathrm{~A}$ & $14798 \mathrm{C}$ & $5426 \mathrm{C}$ \\
\hline & & & & $4769 \mathrm{G}$ & $16069 \mathrm{~T}$ & $(10876 \mathrm{G})$ \\
\hline & & & & $5390 \mathrm{G}$ & $16126 \mathrm{C}$ & $(11467 G)$ \\
\hline & & & & $5426 \mathrm{C}$ & 16519C & $(12372 \mathrm{~A})$ \\
\hline & & & & $8860 G$ & & $13734 \mathrm{C}$ \\
\hline & & & & $10876 \mathrm{G}$ & & $15907 \mathrm{G}$ \\
\hline & & & & $11719 \mathrm{~A}$ & & $16051 G$ \\
\hline & & & & $12308 \mathrm{G}$ & & $16129 \mathrm{C}$ \\
\hline & & & & $12372 \mathrm{~A}$ & & $(16182 \mathrm{M})$ \\
\hline & & & & $13020 \mathrm{C}$ & & $16183 C$ \\
\hline & & & & $13734 \mathrm{C}$ & & $16189 \mathrm{C}$ \\
\hline & & & & $14180 \mathrm{C}$ & & $16260 \mathrm{~T}$ \\
\hline & & & & $14766 \mathrm{~T}$ & & $16356 \mathrm{C}$ \\
\hline & & & & $15326 \mathrm{G}$ & & $16362 \mathrm{C}$ \\
\hline & & & & $15721 \mathrm{C}$ & & $16519 \mathrm{C}$ \\
\hline & & & & $15907 \mathrm{G}$ & & \\
\hline & & & & $16051 G$ & & \\
\hline & & & & $16129 \mathrm{C}$ & & \\
\hline & & & & $(16182 \mathrm{M})$ & & \\
\hline & & & & $16183 \mathrm{C}$ & & \\
\hline & & & & $16189 \mathrm{C}$ & & \\
\hline & & & & $16260 \mathrm{~T}$ & & \\
\hline & & & & $16356 \mathrm{C}$ & & \\
\hline & & & & $16362 \mathrm{C}$ & & \\
\hline & & & & $16519 \mathrm{C}$ & & \\
\hline
\end{tabular}

Tab. 10. Summary of DNA analyses of six individuals from Schleinbach. Sex, age (years), tooth (FDI), haplogroup and mitotype relative to the rCRS. 
to the head, which were inflicted with both sharp and blunt weapons. Four of them had injuries to the left parietal bone, with lesions at the top and front of the head suggesting that the victims were probably facing their aggressors. ${ }^{112}$ Moreover, the left side of the head is a typical location for attacks by a right-hander. ${ }^{113}$ Males were affected by neurocranial trauma about four times more frequently than females. In the Bronze Age group of Unterhautzenthal, for comparison, $6.9 \%$ of the individuals showed neurocranial fractures, two males and two females, and all lesions - most of them located in the left parietal bones - were healed. ${ }^{114}$

An exceptionally high number of unusual, rare and complicated postcranial fractures characterizes the Schleinbach individuals, for instance the bilateral fracture of the spina scapulae in the male from Feature 1927/2, the severe wrist fracture in the male of Feature 115, and the multiple skull fractures of the boy in Feature 1981/Grube 3. Women were not excluded from violence, as demonstrated by the 18-21-year-old female 1927/1 with two peri-mortem sharp force traumas to the skull and a sharp cut to the left tibia, and indicated by probable parry fractures found in two female individuals. Complex trauma patterns, as documented in the 40-55-year-old female from Pit 56, suggest that the Bronze Age community was able to provide a level of care that ensured survival; and yet, her burial in a pit without grave goods raises questions regarding full social membership.

The two adult male individuals $30 / 31$ buried in close physical contact in one grave were closely related via the maternal line and died of almost identical neurocranial injuries in the same location of their skulls. Whether they were warriors, victims of an attack on the community or executed, they received a formal burial at Schleinbach. The four individuals buried together in the former storage pit 60 , in contrast, seem haphazardly disposed. Two of the individuals from this pit show peri-mortem cranial injuries, and it seems likely that the others died in the same violent event, even if it did not manifest directly on their bones. The proteomic analysis revealed that the adult male was buried with children of both sexes; the 3-4-year-old girl and the 8-9-year-old boy were closely related via the maternal line, whereas the 12-year-old girl and the adult male have distinct matrilines. The age difference between the adult male and the three children makes it possible that he was the father of all of the children, which he would have had with two different female partners. If the younger children had the same

112 Fibiger 2013, 138

113 Kremer, Sauvageau 2009. - Martin, Harrod, Pérez 2012.

114 Rebay-SAlisbury et al. 2018. mother, the sibling age gap is about five years. The possible weaning age after 2-3 years inferred through linear enamel hypoplasias and $\delta^{15} \mathrm{~N}$ isotope data suggests a minimum of 3-4 years between siblings.

A bottleneck in Y-chromosome lineages after Neolithisation around 5000 to $3000 \mathrm{BC}$, in which only one male reproduced for every 17 females, ${ }^{115}$ is currently explained by the formation of patrilineal kin groups. A high level of intergroup competition among these groups reduced the male genetic diversity. ${ }^{116}$ Some men were able to accumulate wealth and power, which translated into reproductive success. High status men might have been able to entertain polygynous relationships and thus monopolize women, leaving low status men fewer chances to reproduce. Competition between males further led to the violent elimination of Y-chromosome linages from the gene pool. The lethal lesions in the males from double burial 30/31, Feature 102, and Pit 60 may be archaeological evidence of male lineage editing.

The children from Pit 60 may have been casualties of a group conflict, but violence seems directly targeted at the 5-6-year-old boy from Feature 1981/Grube 3, who was killed by at least four significant blows to the head. Multiple and bilateral cranial fractures in children are found more frequently in victims of systematic abuse. ${ }^{117}$ The child's poor health status, including traces of scurvy and ear infections, as well as the deposition in a pit underline this assessment.

Burials of young women, adolescents from about 15 years of age, appear to have been carried out with the most care, perhaps a comment on their reproductive potential. The occurrence of a pelvic pattern including a sacral preauricular notch in the adolescent female of 106/1 (1620 years), possibly linked to first giving birth at a young age, and a sacral preauricular extension in 1927/1 (18-21 years) suggest they may have first become mothers in their teenage years. ${ }^{118}$ Sacral preauricular extensions and notches affected $60 \%$ of the females from Schleinbach. The interpretation of pelvic features in relation to pregnancy and parturition is still contested due to uncertainties in the process of their formation and subject to further research on modern, documented skeletal collections. Regardless of their causes, the Pelvic Pattern Index can be a first step toward quantifying pelvic changes for comparison within and between skeletal series, and to the archaeological record. High reference and relevance values may indicate strain experienced through

115 Karmin et al. 2015.

116 Zeng, Aw, Feldman 2018.

117 LEWIS 2013.

118 Pany-Kucera et al. 2019. 
pregnancies and parturitions, but also represent increased activity and stress levels in females as well as hormonal differences compared to males.

Genetic testing has confirmed that individuals that are buried together are frequently closely related. This may also apply to women buried with the remains of (small) children. The 30-35-year old female from Grave 104 was found with the humerus of a foetus/neonate in the $7-8^{\text {th }}$ lunar month, which might indicate she was pregnant. Nothing in the way she was buried suggests any comment on her circumstances; she was placed in a flexed position on her right side. Two bronze hair rings, Spiralröllchen and a few pieces of pottery can be considered typical Bronze Age jewellery and grave goods. Grave 9, equipped with a comparatively rich set of grave goods including pottery, a stone tool and a jewellery set with hair rings and an elaborate dress pin, held the remains of a 45-50-year-old woman and a c. 1.5-year-old child.

As expected in a death sample, ${ }^{119}$ the health status of the individuals from Schleinbach was rather poor, and we found differences between males and females and between individuals buried in graves and pits. Three times more females suffered from caries lesions than men, 5 of 6 individuals affected from intravital tooth loss were female, and sinusitis was found more frequently in females. The disease pattern of rickets (14) and scurvy (105, 106/1, 1981/Grube 3) was found in a few young individuals from Schleinbach. More than $36 \%$ of individuals buried in pits were affected by porotic hyperostosis - an unspecific indicator of stress and deprivation - but only $5 \%$ of individuals buried in graves. The incidence of cribra orbitalia, sinusitis and periostitis is higher in individuals buried in pits. They also suffered more frequently from neurocranial trauma and intravital tooth loss. Such individuals seem to have suffered from deprivation, although some individuals with traumatic lesions and impaired health were also found in formal graves. Individuals whose health is most severely affected, such as the 5-6-year-old boy from Pit 1981/Grube 3 or the 40-55-yearold woman from Pit 56, tend to be disposed of rather than formally buried. The bio-archaeological evidence from Schleinbach points to a high level of social stress and deprivation for at least part of the group.

The curation and handling of body parts, for example of the damaged and severely worn facial skull portion of an adult eventually deposited in Pit 1983/Grube 61, as well as other Early Bronze Age ways of engaging with the dead - the reopening of graves, the disarticulation of bodies and the removal of bones and grave goods - remain difficult to rationalize and explain.

119 Wood et al. 1992.

\section{Acknowledgements}

We would like to thank the staff of the Department of Anthropology at the Natural History Museum in Vienna, in particular Karin Wiltschke-Schrotta and Margit Berner, for granting us access to the skeletal collection and their continued support in consolidating the Schleinbach assemblage. Bernhard Weinzinger assisted with transport, August Walch prepared some of the skeletons for analysis and Wolfgang Reichmann artfully took the photographs. Ernst Lauermann helped us with access to the skeletons under the care of the Museum MAMUZ Schloss Asparn and Norbert Weigl organized their transport to the Natural History Museum in Vienna. Otto Pacher facilitated the relocation of the individuals held at the Museum Korneuburg. Hermann Schwammenhöfer shared photographs, documentation and memories. We thank Wolfgang Breibert from the Landessammlungen Niederösterreich, Bereich Ur- und Frühgeschichte, for access to the photographs taken during the excavations and the permission to print some originals. Thin sections for the tooth cementum annulation analysis were prepared at the Unit of Forensic Anthropology of the Medical University of Vienna in cooperation with Fabian Kanz. We would like to thank Christopher Gerner, head of the Department of Analytical Chemistry of the University of Vienna, for the opportunity to conduct the proteomic analysis. Roderick B. Salisbury digitized the maps, generated Figure 5 and proofread the manuscript. Marlon Bas proofread the catalogue. This study was undertaken within the framework of the ERC project 'The value of mothers to society: responses to motherhood and child rearing practices in prehistoric Europe'. This project has received funding from the European Research Council (ERC) under the European Union's Horizon 2020 research and innovation programme (grant agreement No. 676828).

\section{Appendix 1}

The catalogue of human remains from Schleinbach can be found at: doi: 10.1553/archaeologia104s13-A.

\section{Author Contributions}

Doris Pany-Kucera: skeletal analysis, osteological methodology, writing

Michaela Spannagl-Steiner: skeletal analysis, sampling, catalogue Lukas Waltenberger: excavation of blocks, catalogue, skeletal schemes

Walther Parson, Christina Strobl: DNA analysis

Barbara Rendl: tooth cementum annulation analysis

Lukas Janker: proteomic sex identification

Fabian Kanz: tooth cementum annulation analysis, proteomic sex identification

Katharina Rebay-Salisbury: concept, archaeological analysis, methodology, funding acquisition, interpretation, writing

\section{References}

ACsÁdi, NeMESKÉRI 1970

G. AcsÁdi, J. Nemeskéri, History of Human Life Span and Mortality. Budapest 1970.

Allentoft et al. 2015

M. Allentoft, M. Sikora, K.-G. SJögren, S. Rasmussen, M. Rasmussen, J. Stenderup, P. B. Damgaard, H. Schroeder, T. Ahlström, L. Vinner, A.-S. Malaspinas, A. Margaryan, T. Higham, D. Chivall, N. Lynnerup, L. Harvig, J. Baron, P. Dellla Casa, P. Dabrowski, P. R. Duffy, A. Ebel, A. Epimakhov, K. Frei, M. Furmanek, T. Gralak, A. Gromov, 
S. Gronkiewicz, G. Grupe, T. Hajdu, R. Jarysz, V. Khartanovich, A. Khokhlov, V. Kiss, J. Kolä̈r, A. Krisska, I. Lasak, C. Longhi, G. Mcglynn, A. Merkevicius, I. Merkyte， M. Metspalu， R. Mkrtchyan，V. Moiseyev, L. Paja, G. Pálfi, D. Pokutta, Ł. Pospieszny, T. D. Price, L. SaAg, M. Sablin, N. Shishlina, V. Smrcka, V. I. Soenov, V. Szeverényi, G. Tóth, S. V. Trifanova, L. Varul, M. Vicze, L. Yepiskoposyan, V. Zhitenev, L. Orlando, T. SicheritzPontén, S. Brunak, R. Nielsen, K. Kristiansen, E. WillerSLev, Population genomics of Bronze Age Eurasia, Nature 522, 2015, 167-172.

AlQahtani, Hector, Liversidge 2010

S. J. AlQahtani, M. P. Hector, H. M. Liversidge, Brief communication: the London atlas of human tooth development and eruption, American Journal of Physical Anthropology 142/3, 2010, 481-490.

ANDREws et al. 1999

R. M. Andrews, I. Kubacka, P. F. Chinnery, R. N. Lightowlers, D. M. Turnbull, N. Howell, Reanalysis and revision of the Cambridge reference sequence for human mitochondrial DNA, Nature Genetics 23, 1999, 147.

BACH 1965

H. ВАCH, Zur Berechnung der Körperhöhe aus den langen Gliedmaßenknochen weiblicher Skelette, Anthropologischer Anzeiger 29, 1965, 12-21.

Bandelt, Parson 2008

H. J. Bandelt, W. Parson, Consistent treatment of length variants in the human mtDNA control region: a reappraisal, International Journal of Legal Medicine 122/1, 2008, 11-21.

BAss 1971

W. M. BAss, Human Osteology: A Laboratory and Field Manual of the Human Skeleton. Columbia 1971.

BEAUMONT et al. 2018

J. Beaumont, E.-C. Atkins, J. Buckberry, H. Haydock, P. Horne, R. Howcroft, K. Mackenzie, J. Montgomery, Comparing apples and oranges: why infant bone collagen may not reflect dietary intake in the same way as dentine collagen, American Journal of Physical Anthropology 167, 2018, 524-540.

Bertemes 1989

F. Bertemes, Das frühbronzezeitliche Gräberfeld von Gemeinlebarn: Kulturhistorische und paläometallurgische Studien. Saarbrücker Beiträge zur Altertumskunde 45, Bonn 1989.

BERTRAND et al. 2016

B. Bertrand, G. Robbins Schug, C. Polet, S. Naji, T. Colard, Age-at-death estimation of pathological individuals: a complementary approach using teeth cementum annulations, International Journal of Paleopathology 15, 2016, 120-127.

BLESL 2006

C. BLesL, Das frühbronzezeitliche Gräberfeld von Pottenbrunn. Fundberichte aus Österreich, Materialhefte A15, Vienna 2006.

BLONDiAux et al. 2012

J. Blondiaux, C. Fontaine, X. Demondion, R. M. Flipo, T. CoLard, P. D. Mitchell, M. Buzon, P. Walker, Bilateral fractures of the scapula: possible archeological examples of beatings from Europe, Africa and America, International Journal of Paleopathology 2/4, 2012, 223-230.

BLondiaux et al. 2016

J. Blondiaux, S. Naji, E. Audureau, T. Colard, Cementochronology and sex: a reappraisal of sex-associated differences in survival in past French societies, International Journal of Paleopathology $15,2016,152-163$.

BRANDT et al. 2013

G. Brandt, W. Haak, C. J. Adler, C. Roth, A. Szécsényi-Nagy, S. Karimnia, S. Möller-Rieker, H. Meller, R. Ganslmeier, S. Friederich, V. Dresely, N. Nicklisch, J. K. Pickrell, F. Sirocko, D. Reich, A. Cooper, K. W. Alt, Genographic Consortium, Ancient DNA reveals key stages in the formation of central European mitochondrial genetic diversity, Science 342/6155, 2013, 257-261.

BREITINGER 1937

E. BReitinger, Zur Berechnung der Körperhöhe aus den langen Gliedmaßenknochen, Anthropologischer Anzeiger 14, 1937, 149-274.

BRŮŽEK 2002

J. BRŮŽEK, A method for visual determination of sex, using the human hip bone, American Journal of Physical Anthropology 117, 2002, 157-168.

Buikstra, Ubelaker 1994

J. E. Buikstra, D. H. Ubelaker, Standards for Data Collection from Human Skeletal Remains. Research Series 44, Fayetteville 1994.

BYDON et al. 2014

M. Bydon, V. Fredrickson, R. De la Garza-Ramos, Y. Li, R. A. Lehman Jr., G. R. Trost, Z. L. Gokaslan, Sacral fractures, Neurosurgical Focus 37/1, 2014, E12.

CAMERon 2016

C. M. Cameron, Captives: How Stolen People Changed the World. Lincoln - London 2016.

CAPpellini et al. 2019

E. Cappellini, F. Welker, L. Pandolfi, J. Ramos-Madrigal, D. Samodova, P. L. Rüther, A. K. Fotakis, D. Lyon, J. V. Moreno-Mayar, M. Bukhsianidze, R. Rakownikow Jersie-Christensen, M. Mackie, A. Ginolhac, R. Ferring, M. Tappen, E. Palkopoulou, M. R. Dickinson, T. W. StafFORD, Y. L. Chan, A. Götherström, S. K. S. S. Nathan, P. D. Heintzman，J. D. Kapp，I. Kirillova，Y. Moodley, J. Agusti, R.-D. Kahle, G. Kiladze, B. Martínez-Navarro, S. Liu, M. Sandoval Velasco, M.-H. S. Sinding, C. D. Kelstrup, M. E. Allentoft, L. Orlando, K. Penkman, B. Shapiro, L. Rook, L. Dalén, M. T. P. Gilbert, J. V. Olsen, D. Lordkipanidze, E. Willerslev, Early Pleistocene enamel proteome from Dmanisi resolves Stephanorhinus phylogeny, Nature 574, 2019, 103-107.

Cattaneo, Cappella 2017

C. Cattaneo, A. Cappella, Distinguishing between peri- and post-mortem trauma on bone. In: E. M. J. Schotsmanns, N. Marquez Grant, S. L. Forbes (Eds.), Taphonomy of Human Remains: Forensic Analysis of the Dead and the Depositional Environment. Chichester 2017, 352-368.

ChYleŃski et al. 2017

M. Chyleński, A. Juras, E. Ehler, H. Malmström, J. Piontek, M. Jakobsson, A. Marciniak, M. Dabert, Late Danubian mitochondrial genomes shed light into the Neolithisation of central Europe in the $5^{\text {th }}$ millennium BC, BMC Evolutionary Biology $17 / 1,2017,80$.

Cunningham, Scheuer, Black 2016

C. Cunningham, L. Scheuer, S. Black, Developmental Juvenile Osteology. London 2016. 


\section{Duday 2006}

H.DUDAY, L'archéothanatologie oul'archéologie de la mort (archaeothanatology or the archaeology of death). In: R. L. Gowland, C. J. Knüsel (Eds.), Social Archaeology of Funerary Remains. Oxford 2006, 30-56.

DudAY 2009

H. Duday, The Archaeology of the Dead: Lectures in Archaeothanatology. Oxford 2009.

EDUARDOFF et al. 2017

M. Eduardoff, C. Xavier, C. Strobl, A. Casas-Vargas, W. Parson, Optimized mtDNA control region primer extension capture analysis for forensically relevant samples and highly compromised mtDNA of different age and origin, Genes (Basel) 8/10, 2017

FAZEKAS, KóSA 1978

I. G. Fazekas, F. Kósa, Forensic Fetal Osteology. Budapest 1978.

FIBIGER 2013

L. Fibiger, Misplaced childhood? Interpersonal violence and children in Neolithic Europe. In: C. J. Knüsel, M. A. Smith (Eds.), The Routledge Handbook of the Bioarchaeology of Human Conflict. London 2013, 127-145.

Gupta et al. 2014

P. Gupta, H. Kaur, M. Shankari G S, M. K. Jawanda, N. Sahi, Human age estimation from tooth cementum and dentin, Journal of Clinical and Diagnostic Research 8/4, 2014, ZC07-ZC10.

\section{Hagen 1974}

R. Hagen, Pelvic girdle relaxation from an orthopaedic point of view, Acta Orthopaedica Scandinavica 45/1, 1974, 550-563.

\section{HEIDARI 2011}

B. HEIDARI, Knee osteoarthritis prevalence, risk factors, pathogenesis and features: part I, Caspian Journal of Internal Medicine 2/2, 2011, 205-212.

Jancuska, SPivak, Bendo 2015

J. M. Jancuska, J. M. Spivak, J. A. Bendo, A review of symptomatic lumbosacral transitional vertebrae: Bertolotti's syndrome, International Journal of Spine Surgery 9, 2015, 42.

JANKER et al. 2019

L. Janker, R. L. Mayer, A. Bileck, D. Kreutz, J. C. Mader, K. Utpatel, D. Heudobler, H. Agis, C. Gerner, A. Slany, Metabolic, anti-apoptotic and immune evasion strategies of primary human myeloma cells indicate adaptations to hypoxia, Molecular \& Cellular Proteomics 18/5, 2019, 936-953. doi: 10.1074/ mcp.RA119.001390.

Kagerer, Grupe 2001

P. Kagerer, G. Grupe, Age-at-death diagnosis and determination of life-history parameters by incremental lines in human dental cementum as an identification aid, Forensic Science International $118 / 1,2001,75-82$.

KARMin et al. 2015

M. Karmin, L. SaAg, M. Vicente, M. A. W. Sayres, M. Järve, U. G. Talas, S. Rootsi, A.-M. Ilumäe, R. Mägi, M. Mit', L. Pagani, T. Puurand, Z. Faltyskova, F. Clemente, A. Cardona, E. Metspalu, H. Sahakyan, B. Yunusbayev, G. Hudjashov, M. Degiorgio, E.-L. Loogväli, C. Eichstaedt, M. Eelmets, G. Chaubey, K. Tambets, S. Litvinov, M. Mormina, Y. Xue, Q. Ayub, G. Zoraqi, T. S. Korneliussen, F. Akhatova, J. Lachance, S. Tishroff, K. Momynaliev, F.-X. Ricaut, P. Kusuma, H. Razafindrazaka, D. Pierron, M. P. Cox, G. N. N. Sultana, R. Willerslev, C. Muller, M. Westaway, D. Lambert, V. Skaro, L. Kovačević,
S. Turdikulova, D. Dalimova, R. Khusainova, N. Trofimova, V. Akhmetova, I. Khidiyatova, D. V.Lichman, J. Isakova, E. Pocheshrhova, Z. Sabitov, N. A. Barashrov, P. Nymadawa, E. Mihailov, J. W. T. Seng, I. Evseeva, A. B. Migliano, S. Abdullah, G. Andriadze, D. Primorac, L. Atramentova, O. Utevska, L. Yepiskoposyan, D. Marjanović, A. Kushniarevich, D. M. Behar, C. Gilissen, L. Vissers, J. A. Veltman, E. Balanovska, M. Derenko, B. Malyarchuk, A. Metspalu, S. Fedorova, A. Eriksson, A. Manica, F. L. Mendez, T. M. Karafet, K. R. Veeramah, N. Bradman, M. F. HamMer, L. P. Osipova, O. Balanovsky, E. K. Khusnutdinova, K. Johnsen, M. Remm, M. G. Thomas, C. Tyler-Smith, P. A. Underhill, E. Willerslev, R. Nielsen, M. Metspalu, R. Villems, T. Kivisild, A recent bottleneck of Y chromosome diversity coincides with a global change in culture, Genome Research 25/4, 2015, 459-466.

KHURANA et al. 2014

B. Khurana, S. E. Sheehan, A. D. Sodickson, M. J. Weaver, Pelvic ring fractures: what the orthopedic surgeon wants to know, Radiographics 34/5, 2014, 1317-1333.

KING et al. 2014

T. E. King, G. G. Fortes, P. Balaresque, M. G. Thomas, D. Balding, P. M. Delser, R. Neumann, W. Parson, M. Knapp, S. Walsh, L. Tonasso, J. Holt, M. Kayser, J. Appleby, P. Forster, D. Ekserdjian, M. Hofreiter, K. Schürer, Identification of the remains of King Richard III, Nature Communications 5, 2014, 5631.

KNIPPER et al. 2017

C. Knipper, A. Mittinik, K. Massy, C. Kociumaka, I. KucuKKalipci, M. Maus, F. Wittenborn, S. E. Metz, A. Staskiewicz, J. Krause, P. W. Stockhammer, Female exogamy and gene pool diversification at the transition from the Final Neolithic to the Early Bronze Age in central Europe, Proceedings of the National Academy of Sciences 114/38, 2017, 10083-10088. doi:10.1073/ pnas. 1706355114.

Kremer, Sauvageau 2009

C. Kremer, A. Sauvageau, Discrimination of falls and blows in blunt head trauma: assessment of predictability through combined criteria, Journal of Forensic Sciences 54/4, 2009, 923-926.

KüNZIE, WiTTWER-BACKOFEN 2008

M. KÜNZIE, U. WITTWER-BACKOFEN, Stress markers in tooth cementum caused by pregnancy, American Journal of Physical Anthropology 135, Issue Supplement 46, 2008, 135.

LAUERMANN 1992

E. Lauermann, Sonderbestattungen der frühen Bronzezeit, Praehistorische Zeitschrift 67/2, 1992, 183-200.

LAUERMANN 2003

E. Lauermann, Studien zur Aunjetitz-Kultur im nördlichen Niederösterreich. Universitätsforschungen zur Prähistorischen Archäologie 99, Bonn 2003.

LEWIS 2007

M. E. Lewis, The Bioarchaeology of Children: Perspectives from Biological and Forensic Anthropology. Cambridge 2007.

LEWIS 2013

M. E. LEwis, Sticks \& stones: exploring the nature and significance of child trauma in the past. In: C. J. KNüsEL, M. A. SMiTh (Eds.), The Routledge Handbook of the Bioarchaeology of Human Conflict. London 2013, 39-63. 
LOREILLE et al. 2007

O. M. Loreille, T. M. Diegoli, J. A. Irwin, M. D. Coble, T. J. Parsons, High efficiency DNA extraction from bone by total demineralization, Forensic Science International 1/2, 2007, 191-195.

LOVEJOY, RusSell, HaRrison 1990

C. O. Lovejoy, K. F. Russell, M. L. Harrison, Long bone growth velocity in the Libben population, American Journal of Human Biology 2/5, 1990, 533-541.

Lovejoy et al. 1985

C. O. Lovejoy, R. S. Meinde, R. P. Mensforth, T. J. Barton, Multifactorial determination of skeletal age at death: a method and blind tests of its accuracy, American Journal of Physical Anthropology 68/1, 1985, 1-14.

LOVELL 1997

N. C. Lovell, Trauma analysis in paleopathology, Yearbook of Physical Anthropology 40, 1997, 139-170.

MacLean et al. 2010

B. Maclean, D. M. Tomazela, N. Shulman, M. Chambers, G. L. Finney, B. Frewen, R. Kern, D. L. Tabb, D. C. Liebler, M. J. MAccoss, Skyline: an open source document editor for creating and analyzing targeted proteomics experiments, Bioinformatics 26/7, 2010, 966-968.

Martin 2008

D. L. Martin, Ripped flesh and torn souls: skeletal evidence for captivity and slavery from the La Plata Valley, New Mexico, ad 1100-1300. In: C. M. Cameron (Ed.), Invisible Citizens: Captives and their Consequences. Salt Lake City 2008, 159-180.

Martin, Harrod, Fields 2010

D. L. Martin, R. P. Harrod, M. Fields, Beaten down and worked to the bone: bioarchaeological investigations of women and violence in the ancient southwest, Landscapes of Violence 1/1, 2010, Article 3, https://scholarworks.umass.edu/lov/vol1/iss1 (last access 21.9.2020).

Martin, Harrod, Pérez 2012

D. L. Martin, R. P. Harrod, V. R. Pérez, The Bioarchaeology of Violence. Gainesville 2012.

Martin, Saller 1957

R. Martin, K. Saller, Lehrbuch der Anthropologie in systematischer Darstellung. Stuttgart 1957.

Mathieson et al. 2015

I. Mathieson, I. Lazaridis, N. Rohland, S. Mallick, N. Patterson, S. A. Roodenberg, E. Harney, K. Stewardson, D. Fernandes, M. Novak, K. Sirak, C. Gamba, E. R. Jones, B. Llamas, S. Dryomov, J. Pickrell, J. L. Arsuaga, J. M. B. De Castro, E. Carbonell, F. Gerritsen, A. Khokhlov, P. Kuznetsov, M. Lozano, H. Meller, O. Mochalov, V. Moiseyev, M. A. R. Guerra, J. Roodenberg, J. M. Vergès, J. Krause, A. Cooper, K. W. Alt, D. Brown, D. Anthony, C. Lalueza-Fox, W. HaAk, R. Pinhasi, D. Reich, Genome-wide patterns of selection in 230 ancient Eurasians, Nature 528, 2015, 499.

MAYs 2015

S. MAYs, Bilateral scapular fracture in a likely case of assault from mediaeval Ipswich, England, International Journal of Paleopathology 10, 2015, 13-15.

MeCKel 2016

L. A. MeckeL, The Utility of Dental Cementum Increment Analysis for Estimating Season-of-Death in Naturally Decomposed Skeletons. Master Thesis, Texas State University 2016.
MÜller-SCheEsSEL et al. 2013

N. Müller-Scheessel, C. Berszin, G. Grupe, A. Schwentke, A. Staskiewicz, J. Wahl, Ältereisenzeitliche Siedlungsbestattungen in Baden-Württemberg und Bayern. In: N. MülleRSCheEssel (Ed.), ,Irreguläre‘ Bestattungen in der Urgeschichte: Norm, Ritual, Strafe ...? Akten der Internationalen Tagung in Frankfurt a. M. vom 3. bis 5. Februar 2012. Kolloquien zur Vorund Frühgeschichte 19, Bonn 2013, 409-424.

Naji et al. 2016

S. Naji, T. Colard, J. Blondiaux, B. Bertrand, E. d'Incau, J.-P. BocqueT-Appel, Cementochronology, to cut or not to cut? International Journal of Paleopathology 15, 2016, 113-119.

Neugebauer 1991

J.-W. Neugebauer, Die Nekropole F von Gemeinlebarn, Niederösterreich: Untersuchungen zu den Bestattungssitten und zum Grabraub in der ausgehenden Frühbronzezeit in Niederösterreich südlich der Donau zwischen Enns und Wienerwald. Römisch-Germanische Forschungen 49, Mainz 1991.

Neugebauer 1994

J.-W. Neugebautr, Bronzezeit in Ostösterreich. Wissenschaftliche Schriftenreihe Niederösterreich 98-101, Vienna - St. Pölten 1994.

Neugebauer, Neugebauer 1997

C. Neugebauer, J.-W. Neugebauer, Franzhausen: Das frühbronzezeitliche Gräberfeld I. Fundberichte Österreich, Materialhefte A5/1-2, Horn 1997.

NúÑEZ et al. 2016

C. Núñez, M. Baeta, S. Cardoso, L. Palencia-Madrid, N. García-Romero, A. Llanos, M. M. de Pancorbo, Mitochondrial DNA reveals the trace of the ancient settlers of a violently devastated Late Bronze and Iron Ages village, PloS one 11/5, 2016, e0155342-e0155342.

Pany-Kucera, Spannagl-Steiner, Rebay-Salisbury 2018a

D. Pany-Kucera, M. Spannagl-Steiner, K. Rebay-Salisbury, The "auriculate extension": a new indicator of pregnancy and childbirth at the sacrum? Poster presented at the $87^{\text {th }}$ Annual Meeting of the American Association of Physical Anthropologists, $11^{\text {th }}-14^{\text {th }}$ April 2018, Austin, Texas 2018.

Pany-Kucera, Spannagl-Steiner, Rebay-Salisbury $2018 \mathrm{~b}$

D. Pany-Kucera, M. Spannagl-Steiner, K. Rebay-Salisbury, Extracting obstetric histories from pelvic features. Poster presented at the $22^{\text {nd }}$ European Meeting of the Paleopathology Association, $28^{\text {th }}$ August $-1^{\text {st }}$ September 2018, Zagreb 2018.

Pany-Kucera et al. 2019

D. Pany-Kucera, M. Spannagl-Steiner, S. Argeny, B. MaurerGesek, W. J. Weninger, K. Rebay-Salisbury, Sacral preauricular extensions, notches and corresponding iliac changes: new terms and the proposal of a recording system, International Journal of Osteology 29/6, 2019, 1013-1021.

PARKER et al. 2019

G. J. Parker, J. M. Yip, J. W. Eerkens, M. SAlemi, B. Durbin-Johnson, C. Kiesow, R. Haas, J.E. Buikstra, H. Klaus, L. A. Regan, D. M. Rocke, B. S. Phinney, Sex estimation using sexually dimorphic amelogenin protein fragments in human enamel, Journal of Archaeological Science 101, 2019, 169-180.

Parson, Dur 2007

W. PARson, A. DuR, EMPOP - a forensic mtDNA database, Forensic Science International 1/2, 2007, 88-92. 
Parson et al. 2014

W. Parson, L. Gusmao, D. R. Hares, J. A. Irwin, W. R. Mayr, N. Morling, E. Pokorak, M. Prinz, A. Salas, P. M. SchneiDer, T. J. PArsons, DNA commission of the International Society for Forensic Genetics: revised and extended guidelines for mitochondrial DNA typing, Forensic Science International: Genetics 13, 2014, 134-142.

Parson et al. 2018

W. Parson, M. Eduardoff, C. Xavier, B. Bertoglio, M. Teschler-Nicola, Resolving the matrilineal relationship of seven Late Bronze Age individuals from Stillfried, Austria, Forensic Science International: Genetics 36, 2018, 148-151.

Pittioni 1954

R. Pittioni, Urgeschichte des österreichischen Raumes. Vienna 1954.

Probst 1996

E. Рвовsт, Deutschland in der Bronzezeit: Bauern, Bronzegiesser und Burgherren zwischen Nordsee und Alpen. Munich 1996.

Probst 2011

E. РвовSт, Österreich in der Frühbronzezeit. Munich 2011.

RALSTON 2016

C. E. Ralston, Dental cementum increment analysis and estimating season at death in humans. Master Thesis, Boston University 2016.

REBAy-SALISBURy 2018a

K. Rebay-Salisbury, Personal relationships between co-buried individuals in the central European Early Bronze Age. In: G. LILLehammer, E. Murphy (Eds.), Across the Generations: The Old and the Young in Past Societies. Childhood in the Past Monograph Series 8, Stavanger 2018, 35-48.

Rebay-Salisbury 2018b

K. Rebay-SAlisbury, Vielversprechende Ansätze und kleine Irrwege: Die Interpretationsgeschichte frühbronzezeitlicher Bestattungen am Beispiel Schleinbach. In: F. Pieler, P. Trebsche (Eds.), Beiträge zum Tag der Niederösterreichischen Landesarchäologie 2018. Asparn 2018, 45-56.

Rebay-Salisbury et al. 2018

K. Rebay-Salisbury, D. Pany-Kucera, M. Spannagl-Steiner, F. Kanz, P. Galeta, M. Teschler-Nicola, R. B. Salisbury, Motherhood at early Bronze Age Unterhautzenthal, Lower Austria, Archaeologia Austriaca 102, 2018, 71-134.

Rebay-Salisbury et al. 2020

K. Rebay-Salisbury, D. Pany-Kucera, L. Janker, D. Schuster, M. Spannagl-Steiner, L. Waltenberger, R. B. Salisbury, F. KAnz, Child murder in the Early Bronze Age: proteomic sex identification of a cold case from Schleinbach, Austria, Archaeological and Anthropological Sciences 12/265, 2020. doi: 10.1007/ s12520-020-01199-8.

Reimer et al. 2013

P. J. Reimer, E. Bard, A. Bayliss, J. W. Beck, P. G. Blackwell, C. Bronk Ramsey, C. E. Buck, H. Cheng, R. L. Edwards, M. Friedrich, P. M. Grootes, T. P. Guilderson, H. Haflidason, I. Hajdas, C. Hatté, T. J. Heaton, D. L. Hoffmann, A. G. Hogg, K. A. Hughen, K. F. Kaiser, B. Kromer, S. W. Manning, M. Niu, R. W. Reimer, D. A. Richards, E. M. Scott, J. R. Southon, R. A. Staff, C. S. M. Turney, J. vAN DER Plicht, IntCal13 and Marine13 radiocarbon age calibration curves $0-50,000$ years cal BP, Radiocarbon 55/4, 2013, 1869-1887.
RESNICK 1995

D. Resnick (Ed.), Diagnosis of Bone and Joint Disorders. Philadelphia 1995.

RetTEnBaCher 2004

M. RetTenbacher, Die Siedlung und die Gräberfelder von Schleinbach: Eine Studie zur Aunjetitz-Kultur im südlichen Weinviertel. Archäologische Forschungen in Niederösterreich 2, St. Pölten 2004.

Reynard, Tuross 2015

L. M. Reynard, N. Tuross, The known, the unknown and the unknowable: weaning times from archaeological bones using nitrogen isotope ratios, Journal of Archaeological Science 53, 2015, 618-625.

RodRigues-Pinto et al. 2017

R. Rodrigues-Pinto, M. F. Kurd, G.D. Schroeder, C. K. Kepler, J. C. Krieg, J. H. Holstein, C. Bellabarba, R. Firoozabadi, F. C. Oner, F. Kandziora, M. F. Dvorak, C. P. Kleweno, L. R. Vialle, S. Rajasekaran, K. J. Schnake, A. R. Vaccaro, Sacral fractures and associated injuries, Global Spine Journal 7/7, 2017, 609-616.

RuFf et al. 2006

C. B. Ruff, B. M. Holt, V. Sladek, M. Berner, W. A. Murphy Jr., D. zur Nedden, H. Seidler, W. Recheis, Body size, body proportions, and mobility in the Tyrolean "Iceman", Journal of Human Evolution 51/1, 2006, 91-101.

RuFf et al. 2012

C. B. Ruff, B. M. Holt, M. Niskanen, V. Sladék, M. Berner, E. Garofalo, H. M. Garvin, M. Hora, H. Maijanen, S. NIinimäKi, K. SAlo, E. Schuplerová, D. Tompkins, Stature and body mass estimation from skeletal remains in the European Holocene, American Journal of Physical Anthropology 148/4, 2012, 601-617.

SCHWAMMENHÖFER 1982

H. SchwammenhÖFER, Schleinbach, Gem. Ulrichskirchen-Schleinbach, BH Mistelbach, Fundberichte aus Österreich 20/1981, 1982, 380-391.

SChWAMMENHÖFER 1984

H. SchwammenhÖFER, Schleinbach, Gem. Ulrichskirchen-Schleinbach, BH Mistelbach, Fundberichte aus Österreich 22/1983, 1984, 244-245.

SCHWAMMENHÖFER 1986a

H. SCHWAmmenhöFeR, KG Schleinbach, MG UlrichskirchenSchleinbach, VB Mistelbach, Fundberichte aus Österreich 23/1984, 1986, 233.

SCHWAMMENHÖFER 1986b

H. SchwammenhöFer, KG Schleinbach, MG UlrichskirchenSchleinbach, VB Mistelbach, Fundberichte aus Österreich 23/1984, 1986, 242-243.

SCHWAMMENHÖFER 1987a

H. SCHWAmmenhöFER, KG Schleinbach, MG UlrichskirchenSchleinbach, VB Mistelbach, Fundberichte aus Österreich 2425/1985-1986, 1987, 217.

SCHWAMMENHÖFER $1987 \mathrm{~b}$

H. SCHWAmmenhöFeR, KG Schleinbach, MG UlrichskirchenSchleinbach, VB Mistelbach, Fundberichte aus Österreich 2425/1985-1986, 1987, 232.

SJøvOLD 1990

T. SJøvold, Estimation of stature from long bones utilizing the line of organic correlation, Human Evolution 5/5, 1990, 431-447. 
SPRENGER 1999

S. Sprenger, Zur Bedeutung des Grabraubes für sozioarchäologische Gräberfeldanalysen: Eine Untersuchung am frühbronzezeitlichen Gräberfeld Franzhausen I, Niederösterreich. Fundberichte aus Österreich, Materialhefte A7, Vienna 1999.

STECKEL et al. 2006

R. H. Steckel, P. W. Sciulli, C. S. Larsen, P. L. Walker, The Global History of Health: Data Collection Codebook. Ohio 2006.

STEWART et al. 2016

N. A. Stewart, G. F. Molina, J. P. Mardegan Issa, N. A. Yates, M. Sosovicka, A. R. Vieira, S. R. P. Line, J. Montgomery, R. F. Gerlach, The identification of peptides by nanoLC-MS, MS from human surface tooth enamel following a simple acid etch extraction, Royal Society of Chemistry Advances 6, 2016, 61673-61679. doi: 10.1039/C6RA05120K.

STEWART et al. 2017

N. A. Stewart, R. F. Gerlach, R. L. Gowland, K. J. Gron, J. Montgomery, Sex determination of human remains from peptides in tooth enamel, Proceedings of the National Academy of Sciences 114/52, 2017, 13649-13654.

StockHAmmer et al. 2015

P. W. Stockhammer, K. Massy, C. Knipper, R. Friedrich, B. Kromer, S. Lindauer, J. Radosavljević, F. Wit'tenborn, J. Krause, Early Bronze Age chronology: evidence from largescale radiocarbon dating, PLoS one 10/10, 2015, e0139705.

STUCHLÍk 1990

S. STUснці́к, Die sekundären Eingriffe in den Gräbern der Úněticer Kultur, Anthropologie 28/2-3, 1990, 159-167.

SZILVÁsSY 1988

J. Szilvássy, Altersdiagnose am Skelett. In: R. Knussmann (Ed.), Anthropologie: Handbuch der vergleichenden Biologie des Menschen, Vol. 1/1: Wesen und Methoden der Anthropologie. Stuttgart 1988, 421-443.

Teschler-Nicola 1992

M. Teschler-Nicola, Untersuchungen zur Bevölkerungsbiologie der Bronzezeit in Ostösterreich: Phänetische Analyse kontinuierlicher und nichtkontinuierlicher Skelettmerkmale. Habilitation Thesis, University of Vienna 1992.

Tilley 2017

L. Tilley, Showing that they cared: an introduction to thinking, theory and practice in the bioarchaeology of care. In: L. TILLEY, A. A. Schrenk (Eds.), New Developments in the Bioarchaeology of Care: Further Case Studies and Expanded Theory. Bioarchaeology and Social Theory, Cham 2017, 11-43.

TrotTer 1964

M. Trot'ter, Accessory sacroiliac articulations in East African skeletons, American Journal of Physical Anthropology 22/2, 1964 , 137-141.

VAN Oven, KaYser 2009

M. van Oven, M. Kayser, Updated comprehensive phylogenetic tree of global human mitochondrial DNA variation, Human Mutation 30/2, 2009, E386-94.

WEDEL, WESCOTT 2016

V. L. Wedel, D. J. WescotT, Using dental cementum increment analysis to estimate age and season of death in African Americans from an historical cemetery in Missouri, International Journal of Paleopathology 15, 2016, 134-139.
WENINGER 1941

J. WENINGER, Eine seltsame Mehrbestattung aus der frühen Bronzezeit von Schleinbach in Niederdonau. Niederdonau - Natur und Kultur 10, 1941, 3-38.

WENINGER 1954 a

J. Weninger, Frühbronzezeitliche Skelette aus Schleinbach in Niederösterreich, Teil 1: Eine seltsame Mehrbestattung aus Schleinbach (NÖ), Archaeologia Austriaca 16, 1954, 1-27.

WENINGER 1954b

M. Weninger, Frühbronzezeitliche Skelette aus Schleinbach in Niederösterreich, Teil 2: Die Einzelbestattungen aus Schleinbach (NÖ), Archaeologia Austriaca 16, 1954, 28-66.

White, Black, Folkens 2012

T. D. White, M. T. Black, P. A. Folkens, Human Osteology. Amsterdam 2012.

WitTwER-BACKOFEN, GAMPE, VAuPEL 2004

U. Wittwer-Backofen, J. Gampe, J. W. Vaupel, Tooth cementum annulation for age estimation: results from a large known-age validation study, American Journal of Physical Anthropology 123/2, 2004, 119-129.

Wood et al. 1992

J. W. Wood, G. R. Milner, H. C. Harpending, K. M. Weiss, M. N. Cohen, L. E. Eisenberg, D. L. Hutchinson, R. Jankauskas, G. Cesnys, G. Česnys, M. A. Katzenberg, J. R. Lukacs, J. W. McGrath, E. A. Roth, D. H. Ubelaker, R. G. Wilkinson, The osteological paradox: problems of inferring prehistoric health from skeletal samples, Current Anthropology 33/4, 1992, 343-370.

Xavier et al. 2019

C. Xavier, M. Eduardoff, C. Strobl, W. Parson, SD quants sensitive detection tetraplex-system for nuclear and mitochondrial DNA quantification and degradation inference, Forensic Science International: Genetics 42, 2019, 39-44. doi: 10.1016/j. fsigen.2019.06.004.

Zeng, Aw, Feldman 2018

T. C. Zeng, A. J. Aw, M. W. Feldman, Cultural hitchhiking and competition between patrilineal kin groups explain the postNeolithic Y-chromosome bottleneck, Nature Communications 9/1, 2018, 2077.

Doris Pany-Kucera

Institute for Oriental and European Archaeology Austrian Academy of Sciences Hollandstraße 11-13 1020 Vienna Austria

doris.pany-kucera@oeaw.ac.at orcid.org/0000-0003-4140-3220

Michaela Spannagl-Steiner Institute for Oriental and European Archaeology Austrian Academy of Sciences Hollandstraße 11-13 1020 Vienna Austria michaela.spannagl@oeaw.ac.at orcid.org/0000-0002-6927-8284 
Lukas Waltenberger

Institute for Oriental and European Archaeology Austrian Academy of Sciences Hollandstraße 11-13 1020 Vienna Austria

lukas.waltenberger@oeaw.ac.at orcid.org/0000-0002-9670-6117

Walther Parson Institute of Legal Medicine Innsbruck Medical University Müllerstraße 44 6020 Innsbruck Austria walther.parson@i-med.ac.at orcid.org/0000-0002-5692-2392

Christina Strobl Institute of Legal Medicine Innsbruck Medical University Müllerstraße 44 6020 Innsbruck Austria christina.strobl@i-med.ac.at D orcid.org/0000-0001-6059-243X

Barbara Rendl Institute for Oriental and European Archaeology Austrian Academy of Sciences Hollandstraße 11-13 1020 Vienna Austria barbara.rendl@gmail.com orcid.org/0000-0003-0698-1893

Lukas Janker Department of Analytical Chemistry University of Vienna Wäbringer Straße 38 1090 Vienna

Austria lukas.janker@univie.ac.at orcid.org/0000-0002-3084-2212

\section{Fabian Kanz}

Unit of Forensic Anthropology Medical University of Vienna

Center for Forensic Medicine

Sensengasse 2 1090 Vienna Austria fabian.kanz@meduniwien.ac.at orcid.org/0000-0001-6720-6781

\author{
Katharina Rebay-Salisbury \\ Institute for Oriental and European Archaeology \\ Austrian Academy of Sciences \\ Hollandstraße 11-13 \\ 1020 Vienna \\ Austria \\ katbarina.rebay-salisbury@oeaw.ac.at \\ (iD) orcid.org/0000-0003-0126-8693
}

